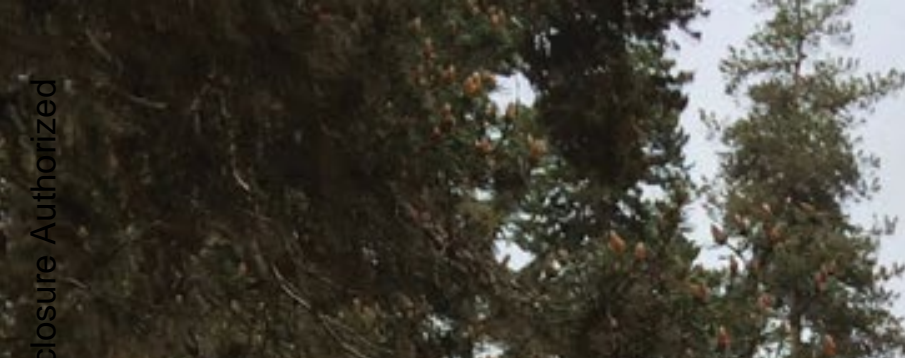

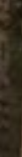$$
\text { a. }
$$

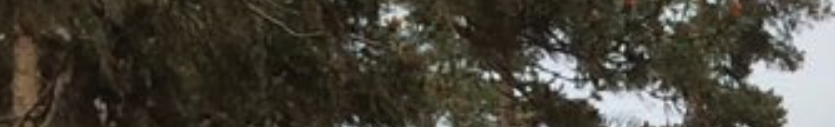

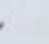

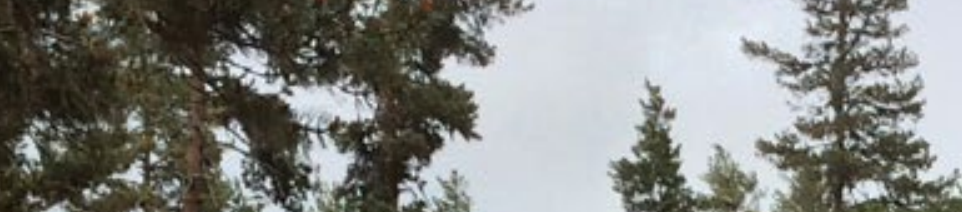
$54 x^{-1}$ ?

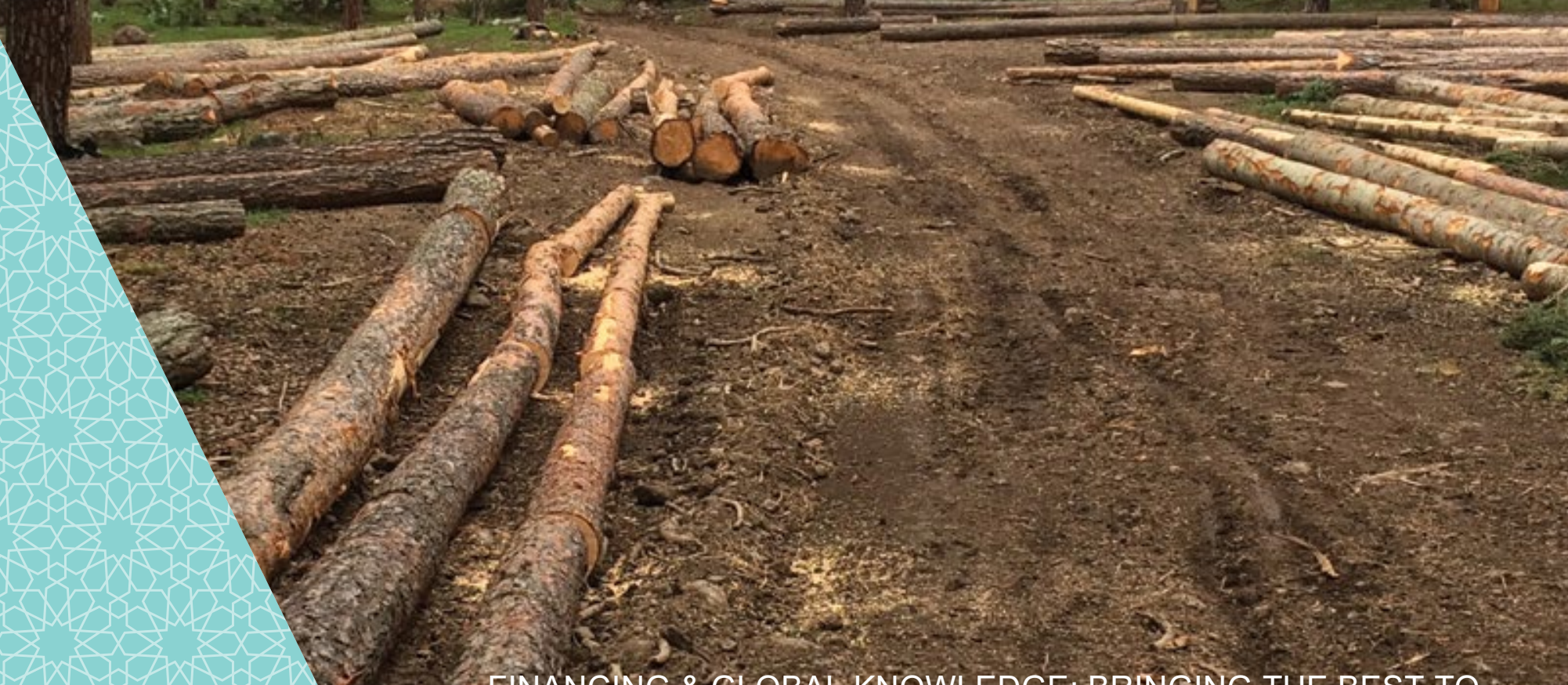

FINANCING \& GLOBALENOWLEDGE: BRINGING THE BEST TO TURKEY AND SHARING THE BEST OF TURKEY WTTH THE WORLD 



\section{TABLE OF CONTENTS}

ACRONYMS AND ABBREVIATIONS $\quad 4$

ACKNOWLEDGEMENT $\quad 6$

EXECUTIVE SUMMARY $\quad 7$

1. INTRODUCTION

$\begin{array}{ll}1.1 \text { General } & 19\end{array}$

1.2 Related Sectors

1.3 International Forestry and Forest Policy Context 21

1.4 UN 2030 Agenda for Sustainable Development 23

$1.5 \mathrm{EU} \quad 23$

1.5.1 EU Forest Strategy

1.5.2 EU 2020 Strategy

2. THE FOREST SECTOR

2.1 Forest Resources $\quad 27$

2.2 The Legislative, Policy and Institutional Framework 29

2.2.1 Forest Policy and Strategy

2.2.2 Legislation 30

2.2.3 Forest Institutions

2.2.4 Stakeholders 39

2.2.5 Forest Cadaster $\quad 40$

2.3 Forest Monitoring, Evaluation and Research $\quad 40$

2.3.1 Forest Management $\quad 40$

2.3.2 National Forest Inventory

2.3.3 Forest Research, Evaluation and Technology $\quad 42$

2.4 Forest Management Activities $\quad 43$

2.4.1 General 43

2.4.2 Forest Protection 43

2.4.2 Afforestation 46

2.4.3 Forest Roads

2.4.4 Wood Production and Sales 48

2.4.5 Wood Energy

2.4.6 Hunting and Game Management

2.4.7 Non-wood Forest Products and Ecosystem Services

a) Non-wood Forest Products (NWFPs) 50

b) Ecosystem Services 53

c) Economic Value of Ecosystem Services 53

2.5 Socio-economic and Environmental Functions and Services $\quad 55$

2.5.1 State Forestry Sector and Forest Villages

2.5.2 Historical Background and Trends of Support to Forest Villages

2.5.3 Current Forestry Sector Support and Future Needs 57

2.5.4 Socio-economic Survey of Forest Villagers 58

a) Demographics of Forest Villages 59

b) Income Sources 59

c) Income Diversification and Forest Dependency 63

d) Outside Support (GDF/ORKOY/Cooperatives) 65

e) Migration 65 
$\begin{array}{ll}2.5 .5 \text { Conclusions } & 70\end{array}$

2.6 Climate Change and Biodiversity 71

2.6.1 Climate Change $\quad 71$

2.6.2 Forestry's Contribution to the Intended Nationally Determined Contribution (INDC 73

2.6.3 Biodiversity 76

2.7 Role of Private Sector Wood Industry / SMEs 77

2.8 Public Involvement and Participation 79

2.9 Forest Certification, FOREST EUROPE and Impact of the EU
Timber Regulation and the US Lacey Act

$\begin{array}{ll}2.9 .1 \text { Forest Certification } & 79\end{array}$

2.9.2 FOREST EUROPE

2.9.3 Rovaniemi Action Plan 82

2.9.4 EU Timber Regulation and US Lacey Act 82

2.10 Forests and Integrated Water Basin Management (multi-sectoral approach) 83

2.11 Fiscal Issues (financing forest management) 83

2.11.1 General Revenues and Costs $\quad 85$

2.12 Linkages of the Forestry Sector to the Rest of the Economy 87

3. CHALLENGES AND OPPORTUNITIES FOR IMPROVED SFM 89

3.1 General

3.2 Forest Resource Information 89

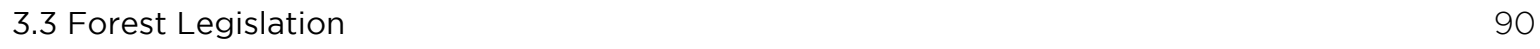

3.4 Improving Competitiveness 91

3.5 Enhanced Wood Supply 92

3.6 Sustainability of Forest Resources 93

$\begin{array}{ll}3.7 \text { Role of GDF } & 94\end{array}$

Appendix 1: International Conventions, Agreements and Initiatives Relevant to Forests 97

Appendix 2: Legislation 100

Appendix 3: Determinants of Migration 101

Appendix 4: Turkey's Intended National Determined Contribution (INDC) 102

Appendix 5: SFM Criteria and Indicators 106

Appendix 6: Share of Direct and Indirect Impacts of Growth in the Forestry Sector, 2002

\section{List of Figures}

Figure 1 Forest related bodies and agreements in the UN 22

Figure 2 Outline of forest related bodies within the EU 24

Figure 3 Forest Cover of Turkey 28

Figure 4 Species percentage of Total Forest Area 29

Figure 5 Forest Regulatory Framework 32

Figure 6 Ministry of Forestry and Water Affairs 34

Figure 7 Organization Structure - General Directorate of Forestry 35

Figure 8 Best Practice Forest Institutions 38

Figure 9 Forest Management Planning Process 41

Figure 10 Forest Fires - Area Burned by Year 43

Figure 11 Forest Area Treated Against Pests 44

Figure 12 Illegal Harvesting $\left(\mathrm{m}^{3}\right)$ by year, 2000 - 2016

Figure 13 Observation area installation points in ICP Forest member countries 46 
Figure 14 Active management of NWFPs in 13 European regions 52

Figure 15 Randomized Sample of Forest Villages Surveyed 58

Figure 16 Percentage of Households Collecting Forest Products 61

Figure 17 Income Diversification 63

Figure 18 Most Popular Combination of Income Sources ( percent of households) 63

Figure 19 Estimated Net Emissions / Removals ('OOOt) 72

Figure 20 Turkey's GHG Emissions Target under the INDC 74

Figure 21 Turkey's Forestry INDC Committment 75

Figure 22 Turkey Timber Prices $\left(\$ / \mathrm{m}^{3}\right)$

Figure 23 Panel Industry Production Capacity by Year 78

Figure 24 FOREST EUROPE Resolutions 81

Figure 25 Impact of Forestry Sector on the Rest of the Economy 86

Figure 26 Comparison of the Definitions of Forest In Europe 90

Figure 27 Organisation Operating Environment 95

\section{List of Tables}

Table 1 Forest Area and Growing Stock 27

Table 2 Annual Increment 28

Table 3 Average Annual Increment per hectare 28

Table 4 Example of Strategic Plan Targets - Road Infrastructure 30

Table 5 Historical Development of Forest Legal and Regulatory Framework 31

Table 6 Employment in GDF 36

Table 7 Benchmarking 39

Table 8 Forest Cadastre Coverage 40

Table 9 Functional Forest Management Plans 42

Table 10 Volume of Timber Sold by GDF ('OOO m³) 48

Table 11 GD Nature Conservation and National Park Revenue from Hunting ('OOO US\$) 50

Table 12 Total Economic Value of Forest Goods and Services in Bolu 2013

Table 13 Support to Forest Villages (FTE = Fulltime Equivalent) 58

Table 14 Survey Sample 59

Table 15 Household Demographic Status by Stratum 59

Table 16 Household Income Sources, Productivity and Participation Rates 60

Table 17 Average Annual Household Sales of Products (TL) 62

Table 18 Income Earning Strategies and Forest Dependency ( percent) 64

Table 19 The Distribution of Household Migration Status by Stratum (percent) 65

Table 20 Village Out-migration Rate (per 1000 persons) 66

Table 21 Reasons for Migration ( percent) 67

Table 22 Household Socio-demographic Profile by Migration Status 67

Table 23 Average Income by Household Migration Status (TL) 68

Table 24 Estimated Probability of Migration and Policy Simulation 70

Table 25 Climate Change Activities 2009-2016 (ha) 72

Table 26 Amount and Share of Forests in INDC 76

Table 27 Forest Area Certified 80

Table 28 Revenues and Costs GDF ('OOO US\$) 84

Table 29 Top 15 Sectors with Linkages to the Forestry Sector (percent) 86 


\title{
ACRONYMS AND ABBREVIATIONS
}

\author{
AAC Annual Allowable Cut \\ AEG Active Energy Group Plc \\ AGTF Association of Green Turkey Foresters \\ CFP Certified forest products \\ $\mathrm{CHP} \quad$ Combined heat and power \\ $\mathrm{CO}_{2} \quad$ Carbon Dioxide \\ $\mathrm{CoC} \quad$ Chain of Custody \\ COP Conference of the Parties \\ CPI Corruption Perception Index \\ CPS Country Partnership Strategy \\ CW Controlled Wood \\ C\&I Criteria and Indicators (for sustainable forest management) \\ DHKV Foundation for Protection of Natural Life \\ EBIT Earnings Before Interest and Tax \\ EIA Environmental Impact Assessment \\ EMEA Eastern Europe, Middle East and Africa (region) \\ ENFIN European National Forest Inventory Network \\ EU European Union \\ FAO Food and Agriculture organization of the United Nations \\ FPN Forest Policy Note \\ FTE $\quad$ Full Time Equivalent \\ FVDF Forest Village Development Fund \\ FRMP Forest Research Master Plan \\ FSC Forest Stewardship Council \\ GCC General Coordinating Committee (FOREST EUROPE) \\ GDCDE General Directorate of Combating Desertification and Erosion \\ GDF General Directorate of Forestry \\ GDFVR General Directorate of Forest-Village Relations \\ GDCNP General Directorate of Nature Conservation and National Parks \\ GDP Gross Domestic Product \\ GDWM General Directorate of Water Management \\ GHG Greenhouse Gas \\ IDHYKK Climate Change and Weather Management Coordination Committee \\ IFF Intergovernmental Forum on Forests \\ INDC Intended Nationally Determined Contribution \\ IPF Intergovernmental Panel on Forests \\ JICA Japan International Cooperation Agency \\ MAF Ministry of Agriculture and Food \\ MDF Medium Density Fibreboard \\ MDG Millennium Development Goal
}




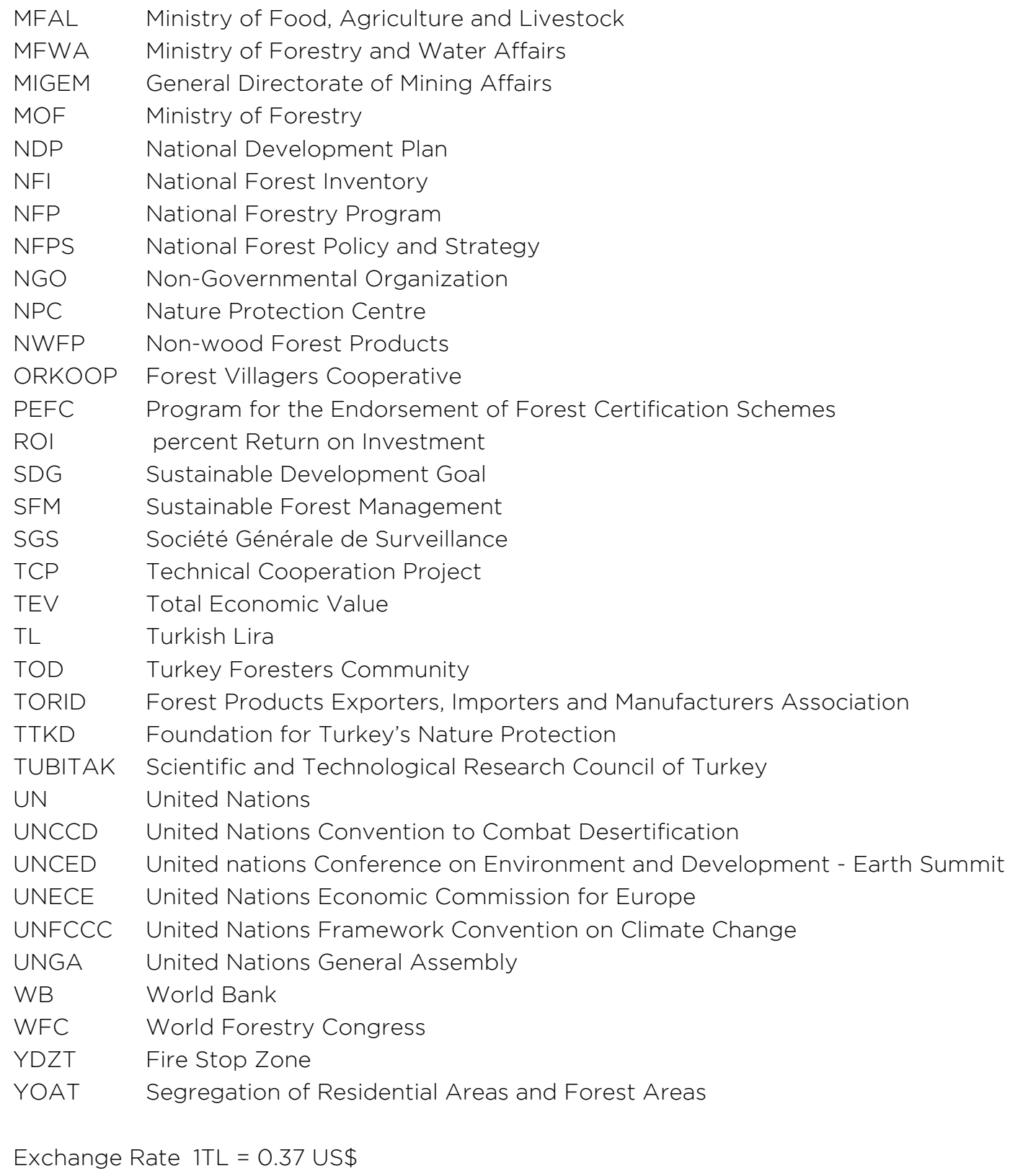




\section{Acknowledgement}

This note was prepared by a combined team of World Bank staff and FAO, and Turkish consultants working in close collaboration with local stakeholders. The team is grateful for the contributions and support provided by the FAO under the FAO/CP programme. The team also acknowledges the cooperation of the General Directorate of Forestry, and all other local stakeholders that provided information and contributed with feedback to the draft report. The note also builds on the work of a separate Socioeconomic Analysis of Forest Villagers in Turkey undertaken by the World Bank in 2016 and funded by the Program for Forests (PROFOR). This draft report was revised following peer review by World Bank staff.

1. The Team comprised: Craig Meisner (World Bank, Task Team Leader and Sr Environmental Economist), Andrew Mitchell (World Bank, Sr Forestry Specialist), Esra Arikan (World Bank, Sr Environmental Specialist), Henry Phillips (FAO, Sr Forestry Consultant) and Mevlut Düzgün (Sr Forestry Consultant). 


\section{EXECUTIVE SUMMARY}

Introduction: This Forest Policy Note, prepared by the World Bank, offers an outside view of the Turkish Forestry Sector, provides some strategic guidance to help define sector goals, and identifies opportunities for consideration in the continued development of the sector and for the implementation of the Turkish/World Bank Country Partnership Strategy which recognizes that the sustainable management of natural resources and nature protection are growing in importance as long-term challenges, along with climate change adaptation.

International Context: National forest policy needs to consider both international and regional forest policy frameworks together with relevant international conventions, agreements and initiatives that impact or have the potential to impact on the sector. International forest policy has become part of the broader "global policy for sustainable development" package. Forest issues at global level are linked to overriding concerns such as global north-south relations, anti-poverty programs, global environmental change, indigenous people's rights and overall goals such as the UN's Millennium Development Goals, MDGs. With a broader agenda for forests, enhanced stakeholder role and a trend towards decentralization of decisions, there is an increasing shift from government to governance.

Forest Resource: Turkey has 22.34 million ha of forest ${ }^{2}$ or 28.6 percent of the land area. Forests are 99.9 percent owned by the State. The forest area has increased by 2.14 million ha since 1973 due to afforestation and forest in-growth on abandoned lands. The definition of forest in Turkey, which is at variance with $\mathrm{FAO}$ definition, results in the area of private forest being significantly understated. The average annual increment of $2.05 \mathrm{~m}^{3}$ per ha compares with a European (excluding Russia Federation) average of $5.4 \mathrm{~m}^{3}$ per ha. The annual allowable cut (AAC) is $18-20$ million $\mathrm{m}^{3}$ or approximately 44 percent of the increment. This compares with a European Union average of 73 percent for fellings as a percentage of increment. In Turkey, extraordinary allowable cuts including additional fellings e.g., windblow, fire, disease typically average 4-5 million $\mathrm{m}^{3}$.

Forest Policy and Strategy: The general policy in Turkey is defined by the Ministry of Development through the National Development Plan. The main policy documents are the Tenth Development Plan (2014-2018), the National Forestry Program (20042023), the Strategic Plan of the Ministry of Forestry and Water Affairs (2013-2017) and the General Directorate of Forestry's Strategic Plan (20132017) ${ }^{3}$. The Ministry of Forestry and Water Affairs (MFWA) is responsible for preparation of plans for combating desertification and erosion and carrying out activities concerning protected areas, national parks and hunting. The General Directorate of Forestry (GDF), within the MFWA, is responsible for integration of the policy and supervision of the implementation. The GDF's strategic plan sets out the overall vision and four main objectives i.e. (1) protect the forests and biodiversity against biotic and abiotic pests, (2) develop and expand the existing forests, increase their efficiency, (3) meet the developing and changing expectations of the public for the forest goods and services and (4) ensure the institutional development for providing sustainable forest management. Overall the policy and strategy are well defined, there are procedures in place to monitor performance. The strategic planning process has opportunities for stakeholder participation.

2. This area of forest is according to the Turkish definition of forest. However, if the Food and Agricultural Organization of the UN definition of forest is applied, approximately 40 percent of this area would be classed as 'other wooded land' and not forest.

3. The General Directorate of Forestry's Strategic Plan (2013-2017) was updated to cover the period 2017-2021 and was put into implementation on 01 January 2017. 
Legislation: The Forest Law, adopted in 1956, is wide ranging and addresses forest definition, categories of forest, forest management and protection, forest improvement, development of forest villages, forest fires, in-forest pastures and penalties. It does not address the harvesting of or rights to non-wood forest products (NWFPs) and lacks specific provisions around the national forest inventory and sustainable forest management. The Constitution is a significant source of substantive Forestry Law and Article 169 states that (a) irrespective of ownership, all forests are under control of the State, (b) ownership of the State Forests cannot be transferred and these forests are run by the State and (c) forest borders cannot be reduced except in special circumstances. The GDF enforces the Forest Law and its officers may call on police, gendarmes, village headmen and other law enforcement bodies for assistance.

The main forest legislation was framed over half a century ago and although subject to many amendments suffers from a number of deficiencies including (a) lack of uniformity in the text due to repeated changes, (b) definition of forests at variance with $\mathrm{FAO}$, (c) private sector largely ignored, (d) insufficient importance given to NWFPs, and ( $f$ ) overlap and conflict with other legislation. Other areas where the law can be improved relate to the incorporation of SFM, user rights for NWFPs, methods of sale for wood-based forest products and support for initiatives within the sector. Framework legislation on nature protection, the national biodiversity strategy and action plan still have to be adopted. The draft Nature Protection Law is not in line with the EU acquis.

Forest Institutions: The GDF is the main institution in the sector and is established as a corporate body with responsibility for almost all sustainable forest management activities. It is a large organization employing 39,028 staff in 2016 and is organized along classic forestry lines with a headquarters comprising service, consultative / supervisory and auxiliary units and Regional Directorates (28) and Research Institutes (12) all reporting to the headquarters. Under the Regional Directorates there are Management Directorates (245) and below these Offices of Forest
Management Chiefs $(1,419)$ and Offices (156) dealing with forestation and soil preservation and Offices (310) of other types of chiefs.

The MFWA also includes the General Directorate of Combating Desertification and Erosion (GDCDE), the General Directorate of Nature Conservation and National Parks (GDNCNP), the General Directorate of Water Management (GDWM) and the General Directorate of Meteorology (GDM). The GDCDE works mainly in forestry related fields and supports the sustainable development, expansion of forests and rehabilitation of degraded forest and other lands throughout the country. It has no budget for remedial works apart from specific projects financed by exceptional sources other than MWFA. Thus the rehabilitation of degraded forest lands and other remedial works are paid and implemented by GDF.

The World Bank (WB) review ${ }^{4}$ of state forest institutions drew attention to the wide range of organizational models including integrated state forest and management administrations like the GDF and noted the increase in the establishment of separate forest administration and forest management organizations. The GDF is a centrallycontrolled organization that essentially sets its own targets, monitors itself in terms of performance, audits itself through an internal audit and reports on itself to Government and the public. A simple benchmarking exercise comparing the GDF 2014 outturn with state owned forest organizations in Ireland, Poland and Romania shows that it is the only loss making (loss is equivalent to the special budget) entity and the only entity not paying the state a dividend for the use of the forest asset.

Stakeholders: The settlements and communities, in and/or near the forest areas, where circa 7.09 million forest dependent people (forest villagers) live are the most affected beneficiary stakeholders. The Central Union of Forest Villagers Cooperative (ORKOOP) has 2,493 affiliated cooperatives and 318,005 members throughout the country of which 1,448 and 193,255 are forestry based respectively. There are also unions of civil servants and the Unions of Forest Workers, representative organizations and a number of NGOs active in the sector

4. World Bank (2005). Forest Institutions in Transition: Experiences and Lessons from Eastern Europe. Washington, DC. 
Forest Management Planning and Inventory: Management plans covering national forests were completed between 1963 and 1972 and from then onwards have been updated periodically. While the focus of the earlier management plans was on wood production, current management plans are a balance of ecological, economic, social and cultural functions of forests. Management planning is undertaken by the forest management chief engineer's offices in GDF. The process is well documented and there are opportunities for public consultation. Turkey does not have a National Forest Inventory (NFI) and relies on the amalgamation of information from forest management plans to provide data on forest resources at a national level for policy, planning and for data to comply with its international reporting commitments. National forest policy requires accurate, timely and comprehensive information. A pilot NFI project in 2009 focused on the initial inventory design and methodology and this study could be used as the starting point for any future NFI.

Forest Research: Forestry research activities are carried out by the 12 forestry research institutes, the forestry faculties, other universities and NGOs. All forestry related research studies are funded by the GDF with limited funds for specific research projects allocated by the Scientific and Technological Research Council of Turkey (TUBITAK) and the Ministry of Development. The GDF strategic plan recognizes that there is inadequate information and ongoing research on the effects of climate change and air pollution on forests.

Forest Protection: Approximately 12.5 million ha of forest is located in regions highly sensitive to wild fires. Very successful results have been achieved in combating fires in recent years through the implementation of GDF's fire combat strategy, which reduced the first response time to 15 minutes in areas vulnerable to fire. 9,156 ha of forest burned in 2016. Forests are subject to attack by circa 50 harmful insects. Pest infestations vary depending on prevailing soil, climatic and environmental conditions and can lead to substantial losses. Extraordinary (sanitary) fellings due to biotic factors average between 300-400,000 $\mathrm{m}^{3}$ annually but can be in excess of 1 million $\mathrm{m}^{3}$ in cases of serious outbreaks. Since 2002, the emphasis has been on the more widespread use of biological disease control measures.

Forest Management: The majority (98 percent) of state owned forests are managed based on an age class forest management method. The current annual Program includes 50,000 ha of afforestation, 80,000 ha of erosion control, 10,000 ha of rehabilitation of meadows and 105,000 ha of forest rehabilitation. There is increased emphasis on watershed-based activities and on trying to support the development of rural communities through the planting of suitable (revenue earning) tree species e.g. walnut, almond, olive and pistachio. Of the 5 million ha potentially available for forestation, only a small proportion is suitable for industrial plantations to supply the wood panels sector.

At the end of 2014 a total of 2.4 million ha of forest has been certified to Forest Stewardship Council (FSC). The GDF plans to expand the area under certification to 5,000,000 ha by the end of 2019 . There is no national forest standard for either FSC or PEFC. The GDF is collaborating with the Turkish national standard authority towards the development of a PEFC standard for Turkey.

Forest road density averages $11.2 \mathrm{~m} / \mathrm{ha}$, which compares with 15 to $17 \mathrm{~m} / \mathrm{ha}$ in Scandinavian countries. While there is awareness of the environmental impact of road construction there is no EIA requirement and no best practice environmental guidance. The general perception in the sector is that road standards are appropriate but there is a need to improve construction techniques.

Wood Production and Sales: The GDF is the dominant producer of roundwood and sells 18-21 million $\mathrm{m}^{3}$ annually. Some 36 percent of fuelwood and 0.5 percent of industrial wood is supplied to the villagers at a discounted price. GDF sells its roundwood by auction, standing sale (20 percent) or under guaranteed supply contracts to those enterprises with an annual roundwood intake of $25,000 \mathrm{~m}^{3}$ or greater, and allocated sales to fiberchip sector and paper sector (30-35 percent). The private sector produces circa 3.5 million $\mathrm{m}^{3}$, which is predominantly pulp wood to the wood panels 
sector. The majority (95 percent) of harvesting operations in GDF forests are undertaken by forest villagers and there is a legal obligation to offer this work to villages. The technology used is basic. Average harvesting costs are considered high in comparison with many European countries. This stems from the technology and methods used. There is no well-developed contracting infrastructure and no plans to facilitate the development of one.

Wood Energy: Wood is widely used in rural areas for heating. Consumption (10-11.5 million $\mathrm{m}^{3}$ per year) is decreasing due to migration from the forest villages to urban areas, increasing use of natural gas and solar water heating systems in forest villages. There is limited use of forest residues for energy and the sector is largely undeveloped. The GDF estimates the potential residue market as being 5 to 7 million tons annually. ${ }^{5}$ The guaranteed feedin tariff for electricity generated from renewable sources has had little impact on the use of woody biomass. The increasing raw material demand from the wood panels sector is limiting the material available for energy.

Hunting: The GDNCNP is responsible for the management of the game and wildlife resources. Hunting is organized locally through local hunting associations which are affiliated to Regional Hunting Federations which in turn are represented nationally by the Hunting Confederation. The right to hunt follows the ownership of the land and hunting associations can purchase hunting rights to permitted hunting grounds either from private owners or through the GDNCNP for state lands. There is potential to increase hunting revenues through the development of quality hunting tourism.

Non-wood Forest Products: Turkey is considered rich in terms of NWFPs. To date there has been no systematic management planning or inventory / status for these resources, mainly because the necessary institutional capacity still needs to be built. Only 20 percent of NWFPs receive any form of processing or added value and the majority are exported unprocessed. NWFPs have traditionally been collected by forest villagers at low prices (tariff price). Permission and amount to be collected is decided by the GDF. A NWFP and services department was established in GDF headquarters in 2011 and under the current Strategic Plan there are targets for an inventory of NWFPs by 2017 and measures for their sustainable utilization.

The recent World Bank assessment of forest ecosystem services estimated the value of NWFPs for Turkey as 2.3 USD per hectare per year, compared with an average for Europe of 20.7 USD indicating a significant potential for growth in the future. ${ }^{6}$ This is reinforced by the findings from the EU StarTree project which show that Turkey has not as yet fully exploited the potential for cultivated forms of NWFPs.?

Ecosystem Services: The revised World Bank estimates of the total non-wood forest wealth for Turkey was $\$ 133$ per hectare per year comprising water $\$ 98.40$, NWFPs $\$ 2.40$, habitat $\$ 1.30$ and recreation $\$ 31.20$. A pilot study ${ }^{8}$ in the Bolu region estimated the total economic value (TEV) of forestry value as US\$ 666.3 million. The largest portion of the TEV were the indirect use values arising from ecosystem services. The study showed that the economic value of various forest products and services, which is normally unaccounted for or accounted implicitly in nonforest sectors, is seven times the value currently accounted as the forest sector's contribution. While the study provides some insight into the TEV of Turkey's forests, the results will need to be validated before they could be considered sufficiently robust to be applied nationally.

Socio-economic: Some 7,096,483 people live in 22,343 forest villages, constituting approximately 9.6 percent of the national population and 40 percent of the rural population. Thirty-five years ago there were some 18 million forest villagers but increased outmigration has reduced the population dramatically. Forest villages are given preferential treatment under

\footnotetext{
5. National initiative and strategy development for strengthening utilization of wood energy in Turkey. Presentation by Ismail Belen to Workshop on Policy options for wood energy. 1-4 June 2010 Minsk, Belarus.

6. Siikamäki, J., Santiago-Ávila, F. and Vail, P. (2015) Global Assessment of Nonwood Forest Ecosystem Services. PROFOR.

7. Wong JLG \& Prokofieva I (Eds) (2014) "State of the European NWFP". StarTree deliverable D1.3. 96 pp.

8. Valuing Forest Products and Services in Turkey: A Pilot Study of Bolu Forest Area, World Bank, 2015.
} 


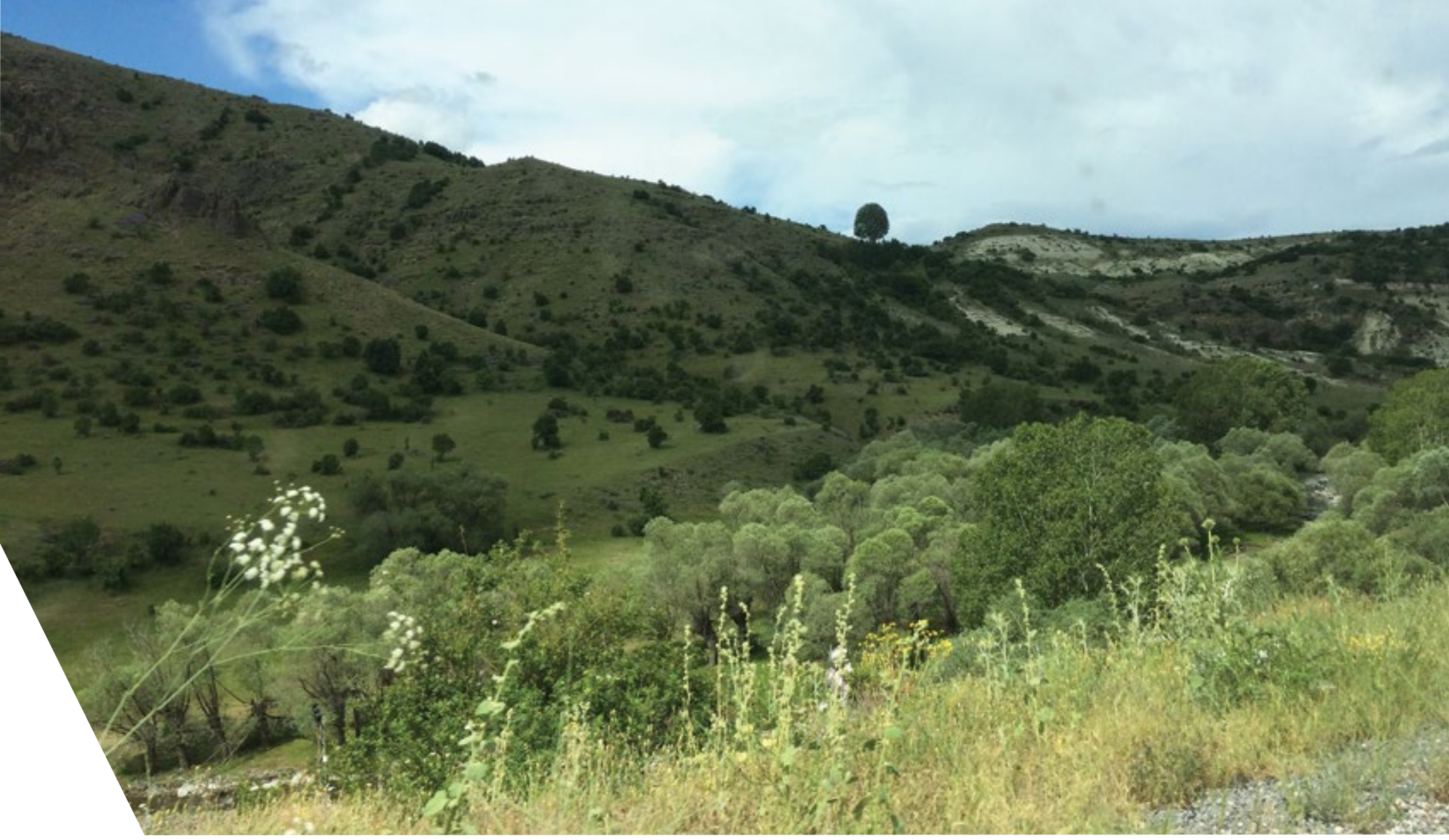

the Forest Law and have a right to employment in harvesting, thinning, afforestation, maintenance and transportation activities undertaken by GDF. They are the GDF's key source of labor and village income is inextricably linked to the sustainability of forests. Despite this co-dependence - forests are playing a smaller role in the livelihoods of forest villagers. In a recent survey of 2,000 forest villagers it was found that income per capita is 3 times less than the national average and although 61 percent of households generated income from either selling or consuming forest products, the highest earnings were from non-forest related activities, pensions, agriculture and livestock income. As a coping strategy, forest villagers typically diversify among several income-generating activities, with the most common being agriculture or livestock sales. Over time, forest wages are playing a smaller contribution to overall income. These findings are also consistent across different areas of Turkey - which can be characterized by high/low poverty and high/low migration rates.
The aim of the Forest and Village Relations Department (ORKOY) in the GDF is to contribute to the protection, development and attainment of the production targets of forests through supporting the socio-economic development of forest villagers. It operates a grant-loan program for individuals and cooperatives. Forest cooperatives are intended to create employment opportunities for cooperative members in the forest. Almost 60 percent of the total roundwood production of Turkey is carried out through cooperatives every year. Forest villagers generate revenues of circa US\$ 350 million annually.

Results from the socioeconomic survey suggest that ORKOY's support to forest villages focuses mainly on providing credit and firewood to households. Among 108 villages (out of 203 surveyed) that reported support, 34 percent received a benefit directly to the household over the past 12 months, 6 percent received a villagelevel development project, and 14 percent received 
both household and village level program benefits. Forty-six percent of villages did not receive any benefits (in cash or in kind), but it should be noted that this was only in the past 12 months.

Despite the long history of government support through establishing forest dependent cooperatives and associations in forest villages, the survey data shows the coverage of membership is relatively low. While about 6 percent of households surveyed were members of forest dependent cooperatives and associations, over 18 percent were members of other cooperatives. Among the members of forest dependent cooperatives (119 households), about 16 percent of households reported to have received employment from the cooperative, which is higher than members of other cooperatives (about 13 percent of households received employment). Support to villages included training and technical assistance, and free seedlings from GDF and other public institutions.

The limited opportunities available to forest villagers is resulting in increased out-migration. The current rate of out-migration over the past year was 15 per 1000 persons, but if a longer time horizon is evaluated, over 10 years, this rate rises to over 100 per 1000 . Half of the households surveyed indicated they already had a member migrate (38 percent) or intend to migrate (14 percent). This was consistent in areas characterized by high/low poverty and high/low migration rates. Among those who have already migrated the most common reason was looking for a job (52 percent), but in low migration areas it was for marriage (55 percent). The unemployment rate in villages was about 11 percent - but there is a lot of underemployment as well. Households who have more limited incomegenerating activities have a higher propensity to migrate. Econometric results suggest that the more forest dependent households are, the more likely they are to have had a migrant, and households belonging to forest cooperatives and associations, are more likely to stay in forest villages. This latter result only holds for the past five years (2010-2015) which may suggest that forest village support schemes may have changed and are viewed as less attractive than before.
Climate Change: Although Turkey became a party to the UNFCCC in 2004, it maintains an expectation that the Annexes will be re-categorized on the basis of state social and economic levels. Turkey became a party to the Kyoto Protocol in 2009, but is not yet subject to emission reduction or limitation obligations. ${ }^{9}$ Turkey submitted its Intended Nationally Determined Contribution (INDC) in September 2015 and set the target of reducing Green House Gas (GHG) emissions by 21 percent from the Business-As-Usual (BAU) by 2030. The GDF is the national coordinator of Land Use Land Use Change and Forestry (LULUCF) and prepares annual GHG inventories. Its climate change working group has responsibility for policy and strategy formulation in relation to climate change.

Turkey is located in the Mediterranean Basin that is especially vulnerable to the adverse impacts of climate change. The Climate Change Strategy (2010-2020) sets out short, medium and long term measures for GHG emissions control across the various sectors including forestry. The forestry measures focus on combating deforestation and forest degradation together with studies on climate change impacts on forest ecosystems and identifying and planting more drought resistant tree species. The Climate Change Action Plan, adopted in 2011, built on this strategy and set out ambitious targets for afforestation and rehabilitation of degraded forests. Targets in the main have been met including afforestation, erosion control and rehabilitation. The forestry sector's contribution to Turkey achieving its INDC is significant. Mitigation activities are projected to reduce $\mathrm{CO}_{2}$ emissions by over 68.7 million equivalent tons representing 12 percent of the 21 percent reduction commitment.

Biodiversity: Forests are home to a wide range of flora and fauna and house significant portions of Turkey's rich natural biodiversity resource. In recent years forest ecosystems have come under increasing pressure through (a) the excessive use of forests in mountain ecosystems without considering their bearing capacity, (b) the impacts of atmospheric pollution and global climate change, (c) pressures from communities living in and around forests, (d) increasing construction due to tourism

9. Kayhan, A.K. Country Report Turkey: Turkey's Climate Change Dilemma. 5 IUCNAEL EJournal 270-276. 
incentives, uplands tourism, (e) alien species, (f) over gathering of plants having an economical value, (g) incorrect mining activities and (h) improper afforestation. ${ }^{10}$ The Law on National Parks outlines the legal framework, defines the status and regulations for the designation and management of protected areas. The total protected area was $6,782,628$ ha at the end of 2015 or 8.7 percent of the land area. This compares with an EU average of 18.1 percent land designated as Natura 2000 sites."

\section{Role of Private Sector Wood Industry / SMEs:}

Turkey has a large wood processing sector. Primary processing is undertaken by an estimated 7,013 sawmills which have been slow to invest and improve technology. There are around 30,000 furniture manufacturers again mainly small scale with only 150

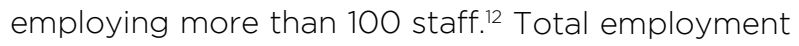
is estimated at 150,000. The furniture industry has seen significant growth over the past decade driven by demand from a growing population, migration to the cities and rising incomes.

Timber prices are considered by the wood industry sector to be relatively high when compared with Europe. This is due in part to the strong demand and rapid growth over the past decade but also to the inefficiencies along the various elements of the timber supply chain. The GDF strategic plan recognizes this prerequisite for future development and has set targets for reducing the ratio of production costs to timber sales revenue from 33 percent in 2013 to 21 percent by 2017 through mainly increasing the proportion of standing sales to 55 percent by 2017 .

Turkey's wood based panels sector has experienced rapid growth due to a boom in the construction industry and rising incomes and is now in the top five panel producer worldwide. There are circa 40 panel mills. The resulting shortfall in raw material, is met through imports and in 2013 Turkey was the second largest chip importer in Europe. ${ }^{13}$ Security of raw material supply is an issue but despite this there are plans for further expansion.
Taking the wood processing sector overall and at current harvesting levels, an estimated 77 percent of domestic demand is met by sales of roundwood from GDF, 15 percent by the private sector with the balance of 8 percent coming from imports.

Rovaniemi Action Plan: The Rovaniemi Action Plan for the Forest Sector in a Green Economy, describes how the forest sector in the United Nations Economic Commission for Europe (UNECE) region could lead the way towards the emerging green economy at the global level. The first draft of the National Action Plan for Forest Sector in a Green Economy was prepared by the MFWA in 2014 with the GDF as the overall coordinator. The plan includes targets for each of the five pillars ((1) Sustainable production and consumption of forest products; (2) A low-carbon forest sector; (3) Decent green jobs in the forest sector; (4) Long term provision of Forest Ecosystem Services; and (5) Policy development and monitoring of the forest sector in relation to a green economy) and identifies the body (department / general directorate) responsible.

EU Timber Regulations: EU Regulation 995/2010 also known as the (Illegal) Timber Regulation counters the trade in illegally harvested timber and timber products covers a wide range of timber products and came into force on 3rd March 2013. Illegal harvesting is at a very low level and shows a decreasing trend over time. According to current statistics about $20,000 \mathrm{~m}^{3}$ are illegally harvested annually, mainly fuelwood at a local level.

Transparency International corruption perception index (CPI) saw Turkey's score decrease from 50 to 45 in 2014. ${ }^{14}$ The $\mathrm{CPI}$ is an integral part of the FSC Controlled Wood (CW) system and a score below 50 places a country in the "unspecified risk" category for legal timber harvesting (indicator 1.4 in the Controlled Wood category 1 - Illegally Harvested Wood). Field verification of legal harvesting is therefore mandatory for companies sourcing CW from such countries.

10. National Biodiversity Strategy and Action Plan 2007

11. Natura 2000 Nature and Biodiversity Newsletter Number 38 June 2015. European Commission.

12. USDA Foreign Agricultural Services Gain Report (2010). Forest Products Report for Turkey.

13. Forest products annual market review 2013-2014. UNECE

14. http://www.transparency.org/whatwedo/publication/cpi2014 
Forests and Integrated Water Basin Management: Forest management is an essential component of integrated basin management. Turkey has gained broad experience in watershed management practices through World Bank financed watershed rehabilitation projects and an FAO technical co-operation project (TCP) as well nationally funded initiatives. The Coruh River Watershed Rehabilitation project (2012-2019), funded by the Japan International Cooperation Agency ( JICA) and the national budget, is addressing integrated watershed rehabilitation with GDF as the coordinating agency. The Murat River Watershed Rehabilitation project (2013-2019), funded by the International Fund for Agricultural Development (IFAD) and national budget, has three components; (a) natural resources and environmental management, (b) investments in natural resources and environmental assets and (c) investments in small-scale agriculture. GDF is the coordinating agency.

Fiscal Issues (Financing Forest Management): The general expectation from Treasury is that the activities of the GDF would be self-financing. However, the funding of expenses for afforestation, erosion control, fire management (control, prevention and extinguishing), soil protection and cadastral works is covered from a special budget provided by the Treasury. The revolving budget comprises mainly revenues from roundwood sales, and is used to offset the major forest management expenses. Thus the revenues coming from the forest resource are in the main returned to forests. As of end-2016, circa 40 percent of revolving fund budget goes towards general administration expenses, 37 percent towards production expenses and costs and the balance 23 percent towards capital investments e.g. forest roads. There is a well-defined budget preparation process. Budgets are monitored monthly at all levels within GDF and where necessary corrective actions are taken.

Over the period 2012 to 2015, the GDF operated at an annual loss of US\$ 411.28 million with the deficit being balanced by matching funds from the Treasury's contribution to the special budget. Revenues from the revolving budget (wood product sales, sales of NWFPs etc.) comprise circa 54 percent of total revenues. The revolving budget is almost totally reliant on roundwood sales which account for 90 percent of revenues and the trend is for this dependency to increase rather than decrease over time. The trend in recent years is for the contribution from the revolving budget to decrease. The Treasury contribution to total revenues varies year on year and was 26.1 percent in 2012, 30.6 percent in 201424.6 percent in 2015, and 21.4 percent in 2016. The reliance on Treasury's contribution and forest product revenues leaves the GDF overly exposed to fluctuations in the national economy and timber markets. The development of other sources of revenue based around the sustainable management of the forest resource will be necessary to provide more stable revenue flows into the future.

\section{Challenges and Opportunities for Improved SFM:}

To ensure that the forest resource can continue to provide valuable functions and support both forest villages and the wood processing sector in a sustainable and cost efficient manner into the future requires that Turkey and the GDF in particular will have to address a number of challenges around (1) forest resource information, (b) forest legislation, (c) improving competitiveness, (d) enhanced wood supply, (e) sustainability of forest resources and ( $f$ ) the role of the State in forestry.

1. Forest Resource Information: The development of society and the increasing awareness of the need to sustainably manage forests, and the reality of climate change, has led to the increasing need for reliable multi-resource information on the status of forests. Reliable, current and consistent information is required to inform domestic forest policy, to support forest research and fulfil national and international reporting commitments. This is currently lacking as there is no National Forest Inventory (NFI) which would record and assess the extent and nature of Turkey's forests, both public and private, in a timely, accurate and reproducible manner to enable the sustainable development of the country's forest resource. The need now is for an NFI design and methodology to be finalised together with the supporting logistics. Once this is finalised the implementation of the NFI 
can be planned and resources allocated. A prerequisite to the $\mathrm{NFI}$ is a change in the definition of forests to align it with FAO which is important especially in terms of common reporting and for comparison / benchmarking between different countries. The changed definition however could have legal ramifications. This could be overcome by including two categories of forest - one for farm forests with a reduced minimum area and including non-native species, and one for natural / semi-natural forests.

Closely aligned with improvement in forest resource information is improved information on the economic contribution of the forest resource to Turkey. The pilot study in the Bolu region highlighted the importance of including values for NWFPs and forestry ecosystem services in any economic analysis of forestry contribution to the economy. Better information on the extent and value of ecosystem services is required if policy and decision makers are to be properly informed when making decisions and or allocating resources within the forestry sector and to enable forest managers to enhance / maximise the economic contribution of forestry to the economy.

2. Legislation: There is now an opportunity to redraft the main Forest Code and in so doing to (a) redress the identified deficiencies, (b) support the competitiveness of the sector through changes in methods for roundwood sales, and (c) incorporate the lessons learned from other countries who have recently redrafted their forest legislation. This would provide the opportunity to fully incorporate the principles of SFM and for integrated management planning covering whole ecosystems, social aspects, environmental and biodiversity values, impacts on climate change and risks of desertification. It also offers the opportunity to incorporate usufruct rights for forest villages for NWFPs and for their sustainable management. Such rights and provisions for sustainable management would facilitate the development of NWFPs.

It is important to have an effective, participatory land use planning process in place to facilitate consensus among concerned sectors of society.
The contents of forestry legislation should be in line with such a process. Participation in this context requires a true commitment to listen and understand the needs, objectives and capacities of the intended users of the law and the forest resource and to finding ways to accommodate the multiple interests at stake. One way to promote greater transparency while at the same time to involve stakeholders would be to establish a forest advisory body representative of the sector as a permanent officially recognised forum for discussion.

3. Improve Competitiveness: Timber and timber products are globally traded commodities. If the wood processing sector in Turkey is to remain competitive and compete with imports, then the GDF, which will remain the dominant supplier of roundwood into the foreseeable future, will have to mobilize its annual production in a more cost-efficient and sustainable fashion, thereby facilitating the development of a competitive domestic roundwood processing sector through reducing costs and reconfiguring the roundwood supply chain.

An analysis of the component processes of the roundwood supply chain is required to provide an up-to-date overview of the current industry cost of timber supply and procurement while identifying a range of efficiency issues relating to the supply chain and the resultant interaction of supplier (principally GDF), purchaser and harvesting entities including villagers and cooperatives. Continued reliance on forest villages for harvesting services is potentially non-viable in the medium to long term in view of their aging and declining population. Changes to increased standing sales and or concessions would only make sense if the contracting infrastructure resource is incentivised to expand and become more efficient.

The GDF is a large centrally controlled organisation that essentially sets its own targets and monitors itself. Competitiveness in any organisation is underpinned by having in place best practice, processes and procedures. While the restructuring of the supply chain will 
impacts at an ecosystem level so that mitigating measures can be developed and put in place thereby ensuring the ongoing provision of the complete range of environmental services from forests. This will be especially true given the forestry sector's contribution to Turkey's INDC.

Sustainability of forest resources is linked with the maintenance and sustainability of biodiversity. There is the potential to improve forest biodiversity, by expanding protected areas, where necessary, and by expanding the use of integrated management in forests outside protected areas. The NFI will help in the monitoring and reporting of biodiversity within forests.

There is general agreement that the area of NWFPs is underdeveloped but has significant potential as a source of local employment and export to European countries. The challenge is how to sustainably exploit this valuable resource for the benefit of rural dwellers and society as a whole. The first steps to ensure the sustainable development of the NWFPs are to (a) identify the resource and its status, (b) identify those NWFPs that offer the best opportunity for harvesting, processing, marketing and export and (c) amend the Forest Law to transfer user rights to forest villages and incorporate provisions for sustainable management. This alongside the development of codes of practice for harvesting and the provision of technical advice on the processing and marketing of NWFPs and increased investment / provision of finance for added value would provide the basis for future development.

The survival and well-being of forest villages is inextricably linked with the sustainability of forest resources owing to their dependence on forests to provide grazing, fuelwood, employment and
NWFPs. The challenge into the future is how the forest can support the livelihood and wellbeing of forest villagers. The current model of villagers undertaking the majority of harvesting and forest works is unsustainable in the medium to long term. Alternatives recognising the limitations of an aging population will need to be developed. Any new model will need to focus on alternative income opportunities and a changed role for villagers in relation to the forest resource. This new model could increase the focus on the harvesting and processing of NWFPs while engaging villagers in a more collaborative approach to forest management at a local level where their role would not merely be suppliers of labour for harvesting and planting but also as caretakers and protectors of the forest, a role less dependent on physical attributes but more on local knowledge and culture. This changed role would have benefits for the sustainability of forest resources while also benefitting rural populations.

6. Role of the State: The GDF has changed parent Ministries and undergone some internal changes in recent years. The challenge for the organisation into the future is to match its role and how it does business with a rapidly changing operating environment and increasing public scrutiny. As a first step in assessing how the organisation fits with its current operating environment and what changes are required as to how it might fit into the future, given the planned changes in the forest sector and broader operating environment, the GDF should undertake an initial business process review at a high level. The initial diagnosis is both crucial and necessary. This together with the benchmarking and re-configuration of the supply chain will provide direction for future change and the delivery of improved services. 
\&

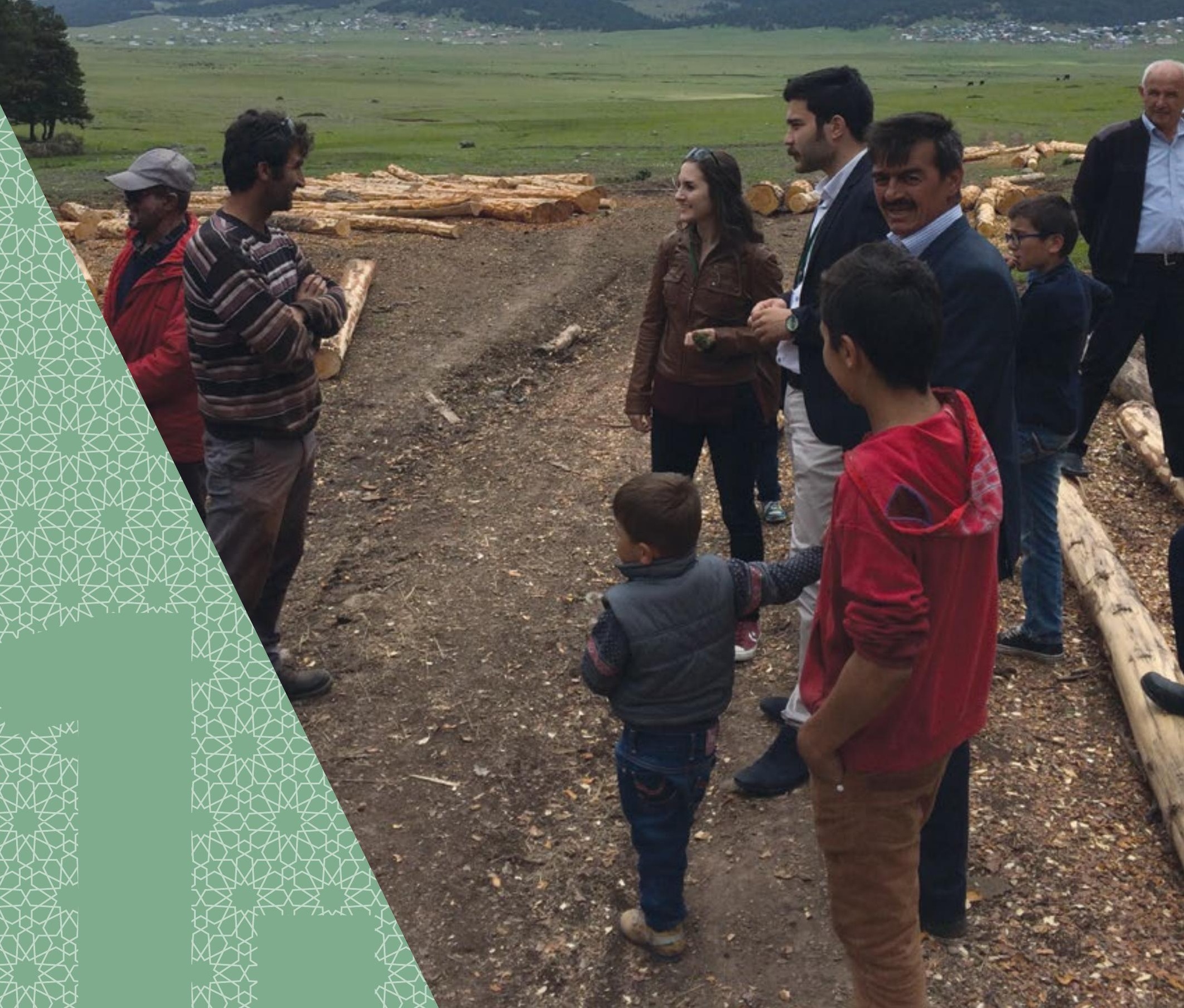




\section{INTRODUCTION}

\subsection{General}

This Forest Policy Note, prepared by the World Bank, offers an outside view of the Turkish Forestry Sector, provides some strategic guidance to help define sector goals, and identifies opportunities for consideration in the continued development of the sector and for the implementation of the TurkeyWorld Bank Country Partnership Framework (CPF). The note aims to offer guidance on how the forest resource can continue to provide environmental goods and services while supporting both forest villages and the wood processing sector in a sustainable and cost efficient manner into the future.

The World Bank (WB) Country Partnership Framework (CPF) for Turkey recognizes that the sustainable management of natural resources and nature protection are growing in importance as long-term challenges for Turkey, along with climate change adaptation. Turkey's natural resources face increasing pressures from growth in energy use, industry, transport, tourism, and agriculture resulting in water stress, soil erosion and pollution. Turkey is already addressing a range of regulatory and institutional reforms in the environment and forestry sectors and prioritizing investment programs in infrastructure, pollution mitigation, and afforestation. Measures to address these challenges are now becoming a priority for the Government.

The forest resource, which is 99.9 percent owned by the State, extends to 22.34 million hat5 or 28.6 percent of the land area of the country is home to a declining and ageing population of 7.09 million rural dwellers spread across 22,343 forest villages who rely heavily on the resource for their livelihood. Despite the level of forest cover, the forest sector production of primary (roundwood) and secondary forest products (non-wood) is estimated to contribute between $0.2-0.3$ percent to GDP'6, reflecting in part the quality of the resource with 10.1 million ha classed as degraded forest but also the missed opportunities for added value particularly in relation to the processing of non-wood forest products.

Turkey's forests are an extremely important asset: they provide multiple environmental services including watershed protection and erosion control, raw material for a world scale wood panels industry, a rich and diverse source of non-wood forest products, employment in rural areas but especially forest villages and fuelwood for large numbers or rural dwellers who have limited access to conventional energy sources.

The development of the sector is guided by the Tenth Development Plan (2014-2018), the National Forestry Program (2004-2023), the Strategic Plan of the Ministry of Forestry and Water Affairs (20132017) and the General Directorate of Forestry's Strategic Plan (2013-2017).

The General Directorate ofForestry, under the Ministry of Forestry and Water Affairs, is responsible for almost all sustainable forest management activities from forest planning through the establishment, growth and maintenance to harvesting. It is a large organization with both administrative, regulatory and management functions.

This Forest Policy Note (FPN) builds on previous work within the forestry sector. It aims to inform the World Bank project formulation process and the forestry sector by reviewing the sector and highlighting the main policy issues and identifying

\footnotetext{
15. This area of forest is according to the Turkish definition of forest. However, if the Food and Agricultural Organization of the UN definition of forest is applied, approximately 40 percent of this area would be classed as 'other wooded land' and not forest.

16. World Bank (2015) Valuing Forest Products and Services in Turkey: A Pilot Study of Bolu Forest Area. Washington: DC
} 
possible actions. This study will assist in identifying and designing investment opportunities within the sector. It is not a forest policy per se, although it could serve as an input to a forest policy formulation process.

\subsection{Related Sectors}

The agriculture and mining sectors impact on forestry through the use of land and resources. The climatic and geographical conditions across the country allow for a wide range of farming activities. Arable farming dominates the agricultural sector accounting for circa 75 percent of value output with the share of fruit and vegetables at circa 44 percent. Arable crops account for 55 percent of agricultural area while 35 percent is pastures and permanent meadows and 8 percent is under perennial crops. The main crops are cereals, other crops such as sugar beet, potatoes, and cotton, vegetables and fruits and other perennial crops. The restructuring efforts that began in the early 1980s, alongside a series of reforms including privatizations and the reduction of trade barriers in the agriculture sector, has resulted in a domestic market that is now an integral part of the world economy.

Turkey's food industry has registered steady growth in recent years, with domestic consumers becoming increasingly demanding, driven by the multitude of choices offered by mass grocery retail outlets. The industry is much better developed than that of neighboring countries and is one of the largest exporters of agricultural products in the Eastern Europe, Middle East and North Africa (EMEA) region, while its trade balance is significantly positive. With growing exports, the Turkish agri-food industry recorded US $\$ 5.6$ billion of trade surplus in 2014.
Turkey's ambitious vision for 2023 envisages a gross agricultural domestic output of US $\$ 150$ billion of which US $\$ 40$ billion will comprise exports and an increase in the irrigation area from 5.4 million ha to 8.5 million ha. The country offers significant investment opportunities in the agribusiness subsectors such as fruit and vegetable processing, animal feed, livestock, poultry, dairy and functional food, aquaculture, and enablers (in particular cold chain, greenhouse, irrigation, and fertilizer).

Turkey has significant reserves of precious and base metals, which coupled with improvements in government mining policy, underpin a growing mining sector. There are approximately 60 different types of minerals currently being mined within the country and it ranks $10^{\text {th }}$ in the world in terms of mineral diversity. The west of the country is generally rich in lignite (brown coal) and the west Black Sea is rich in coal. Several areas are rich in iron. The east is less developed but rich in minerals. Mining can impact on forestry when located in forest areas and with the expansion of the sector the impact is expected to increase over time. Under the current mining application procedure, the Directorate General of Forestry requires the preparation of rehabilitation projects for the area during the term of any permits issued in forest areas. Rehabilitation projects are implemented once the mining activity has been completed.

Mining exports account for a significant amount of the country's GDP. Copper, chrome, coal, marble and boron are the key minerals in the market. Turkey owns 75 percent of the world's boron reserves and the large and diverse mineral resource base includes coal, gold, iron and lead, mercury, silver, tin and other precious metals.

The main regulator is the General Directorate of Mining Affairs (MIGEM) a division of the Turkish Ministry of Energy and Natural Resources, and it is the authorized body which regulates mining activities and issues mining licenses. 


\section{FIGURE 1 FOREST RELATED BODIES AND AGREEMENTS IN THE UN 18}

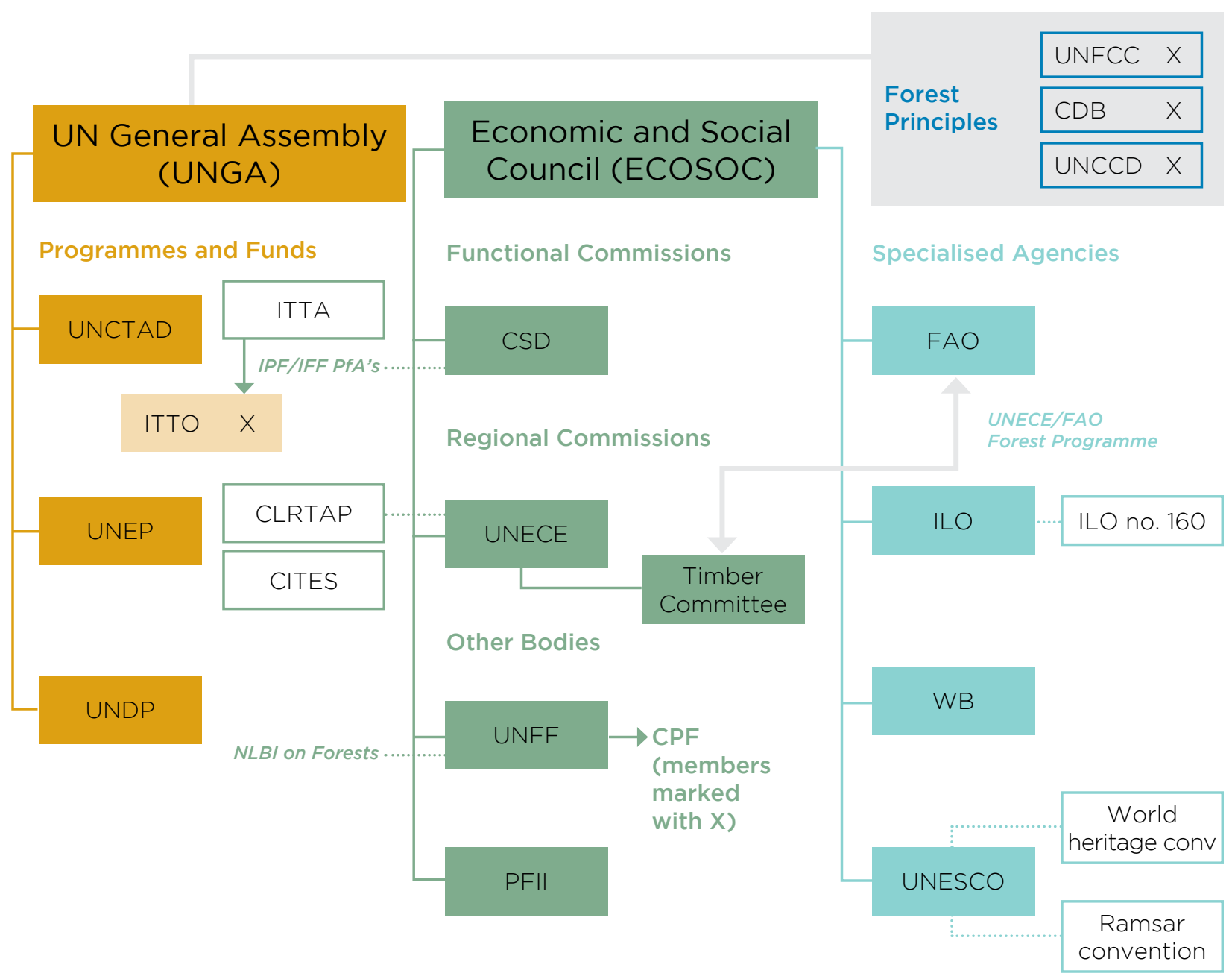

With a broader agenda for forests, stakeholders other than states have acquired a larger role, hand in hand with a trend towards decentralization of decisions related to forest management. There is an increasing shift "from government to governance" resulting in government to a greater extent is being exercised via a network of political stakeholders who exert influence in different ways, at different political levels and by varying means. The number of organizations, political initiatives and various forms of partnership between the public sector, the private sector and civil society has grown considerably in recent years. International partnerships such as Growing Forest Partnerships, The Forests
Dialogue and the International Family Forest Alliance aim to promote the greater involvement of local stakeholders in decisions related to forest management. We have also seen the emergence and establishment of non-state governance in the form of international forest certification systems. The way in which better coordination and synergies are created between various conventions, organizations and initiatives, as well as the links between global, regional and local level, has also been a standing item on many agendas. At global level, the UNFF's Collaborative Partnership on Forests is an initiative to foster coordination of the work of international organizations.

18. Organisations included in the UN Forum of Forest's (UNFF's) Collaborative Partnership on Forests (CPF) are marked with an X. A summary description of each agreement is provided in Appendix 1. 
In summary how the utilization of forest resources is governed is becoming increasingly more complex, involving more stakeholders with decisions making becoming more decentralized and increasing emphasis on the full range of forest services.

\subsection{UN 2030 Agenda for Sustainable Development}

On 1 January 2016, the 17 Sustainable Development Goals (SDGs) of the 2030 Agenda for Sustainable Development- adopted by world leaders in September 2015 at an historic UN Summit officially came into force. Over the next fifteen years, with these new Goals that universally apply to all, countries will mobilize efforts to end all forms of poverty, fight inequalities and tackle climate change, while ensuring that no one is left behind.

The SDGs build on the success of the Millennium Development Goals (MDGs) and aim to go further to end all forms of poverty. The new Goals are unique in that they call for action by all countries, poor, rich and middle-income to promote prosperity while protecting the planet. They recognize that ending poverty must go hand-in-hand with strategies that build economic growth and addresses a range of social needs including education, health, social protection, and job opportunities, while tackling climate change and environmental protection.

While the SDGs are not legally binding, governments are expected to take ownership and establish national frameworks for the achievement of the 17 Goals. Countries have the primary responsibility for follow-up and review of the progress made in implementing the Goals, which will require quality, accessible and timely data collection. Regional follow-up and review will be based on national-level analyses and contribute to follow-up and review at the global level.

\section{$1.5 \mathrm{EU}$}

\subsubsection{EU Forest Strategy}

The EU currently contains 5 percent of the world's forests and EU forests have continuously expanded for over 60 years, although recently at a lower rate. EU Forests and other wooded land now cover 155 million ha and 21 million ha respectively accounting for more than 42 percent of EU land area. Forests are one of Europe's most important renewable resources and provide multiple benefits to society and the economy. They are a key resource for improving the quality of life and job creation, in particular in rural areas, and protect and provide ecosystem services to all citizens.

The EU has no forest policy and each Member State is free to formulate their own forest policy in accordance with the principle of subsidiarity in the EU Treaty. Notwithstanding this, the EU has a long history of contributing through its policies to implementing sustainable forest management and to Member States' decisions on forests. Important developments include: (a) the Europe 2020 strategy for growth and jobs, (b) the Resource Efficiency Roadmap, (c) Rural Development Policy, (d) Industrial Policy, (e) the EU Climate and Energy Package with its 2020 targets, (f) the Plant Health and Reproductive Materials Strategy and ( $g$ ) the Biodiversity and Bio-economy Strategies.

In 2013 the Commission adopted a new Forest Strategy which gives a new framework in response to the increasing demands put on forests and to significant societal and political changes that have affected forests over the last 15 years.

Following a new approach, the Strategy "goes out of the forest", addressing aspects of the value chain i.e. the way forest resources are used to generate goods and services, which strongly influence forest management. The Strategy highlights that forests are not only important for rural development, but also for the environment - especially for biodiversity; for forest-based industries; bioenergy; and in the fight against climate change. Stressing the need of a holistic approach, it also emphasizes that impacts of other policies on forests as well as developments 
FIGURE 2 OUTLINE OF FOREST RELATED BODIES WITHIN THE EU

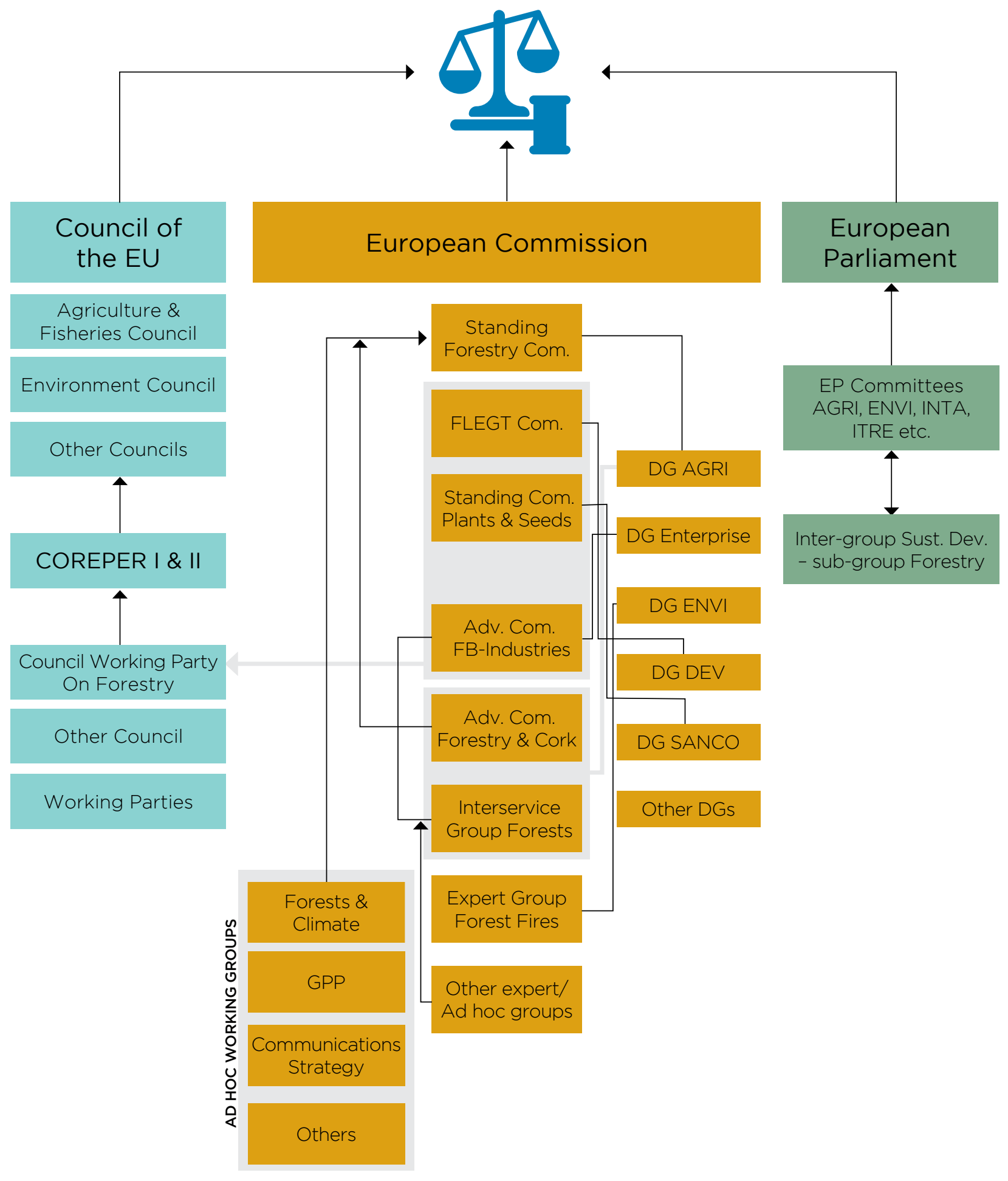


taking place beyond forest boundaries should be taken into account. In addition, the new strategy underlines that forest-linked EU policies should fully be taken into account in national forest policies. Finally, it calls for a Forest Information System to be set up and for Europe-wide harmonized information on forests to be collected.

The strategy, and its implementation, will build on existing legislation and international initiatives, including work carried out under FOREST EUROPE, consider the special situation of small forest owners, and address market-based private-sector tools such as certification. To deliver on common objectives and improve coherence and synergies, coordination with and between Member States will be important. Member States are asked to consider the principles and goals of this strategy when setting up and implementing their action plans and national forest programs.

In practice, responsibility for issues that touch on various aspects of forestry and the forest sector is shared among at least 10 of the Commission's directorates general (DG). The most affected DGs are those for Agriculture and Rural Development (AGRI), Environment (ENVI), Enterprise \& Industry, Energy and Climate Action.

Forest issues are largely the concern of the Standing Forestry Committee, which was established in 1988 within DG AGRI. An Inter-service Group on Forestry was created in 2002 under DG AGRI for the purpose of coordinating more effectively forestry issues that affect several DGs. There is also a corresponding unit for co-ordination of international forestry issues (Inter-service Group on International Forestry Issues).

\subsubsection{EU 2020 Strategy}

In 2010 the EU faced a moment of transformation. The economic crisis has wiped out years of economic and social progress and exposed structural weaknesses in its economy. Concurrently, the world was moving fast and long-term challenges - globalization, pressure on resources, ageing - continued to intensify. The EU needed to act decisively and to take charge of its future and in this regard developed a strategy to help it come out stronger from the crisis and turn the EU in to a smart, sustainable and inclusive economy delivering high levels of employment, productivity and social cohesion.

Europe 2020 sets out a ten-year growth strategy and puts forward three mutually reinforcing priorities: (a) Smart growth: developing an economy based on knowledge and innovation; (b) Sustainable growth: promoting a more resource efficient, greener and more competitive economy; and (c) Inclusive growth: fostering a high-employment economy delivering social and territorial cohesion.

The EU 2020 defines a number of key headline targets with those relating to climate change and energy sustainability (greenhouse gas emissions 20 percent or even 30 percent, if the conditions are right lower than 1990; 20 percent of energy from renewables; and 20 percent increase in energy efficiency) impacting on forests and the forestry sector. To ensure that each Member State tailors the Europe 2020 strategy to its particular situation, the Commission proposed that EU goals are translated into national targets and trajectories. 


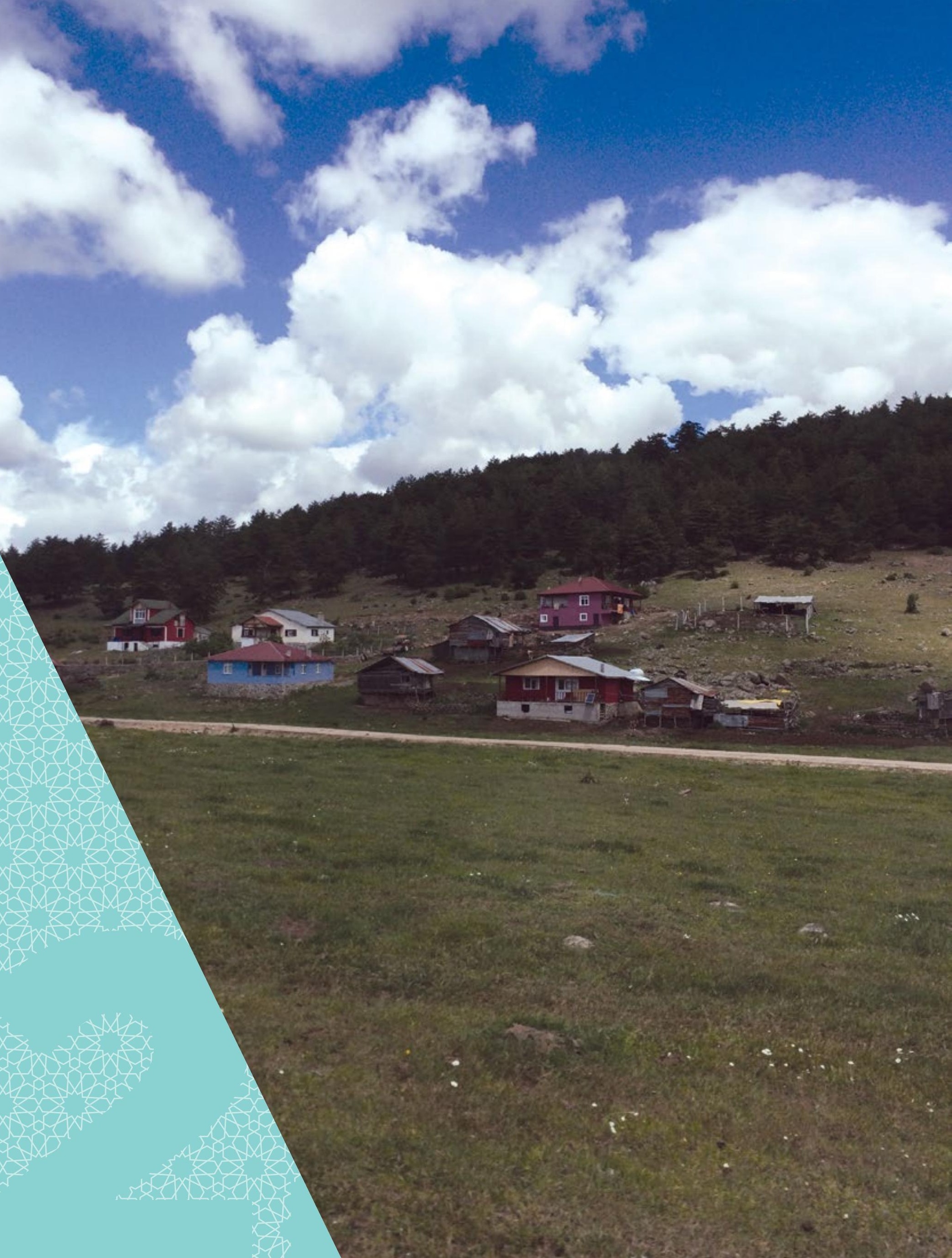




\section{THE FOREST SECTOR}

\subsection{Forest Resources}

Turkey with a land area of 77.8 million ha has a forest area of 22.34 million ha or 28.6 percent. Forests are 99.9 percent owned by the State, reflecting the nationalization of forests in 1945 (Law of Nationalization, Law 4785) in an attempt to safeguard resources and combat over-exploitation. The forest area has increased by 2.14 million ha since 1973 due to afforestation and forest in-growth on abandoned lands. The definition of forest in Turkey excludes areas of forest less than 3 ha and areas with species not found in natural forests. Forest areas with a canopy cover of 10 percent or more are classed as "productive" forest and are required to have an allowable cut identified in the forest management plan. Forest cover is shown in Figure 3.

The area of forests owned by private persons and public entities having a status as a legal entity is approximately 22,000 ha. However due to the definition of forest and the fact that some private land planted with trees is still classed as agricultural land, the area of private forest is significantly understated and it includes an estimated 160,000 - 200,000 ha of high yielding mainly poplar plantations.
Approximately 50 percent of forests are classed as having an economic function including the production of roundwood, fire-wood and nonwood forest products, 42 percent an ecological function including watershed and erosion control and the remaining 8 percent as social and cultural. ${ }^{19}$

Forests in Turkey are divided into two categories, i.e. high forests and coppice ${ }^{20}$ forests, in terms of the way they are managed. High forest, with 19.62 million ha, is the predominant forest type with coppice forests accounting for the remaining 12.18 percent of the forest area. The proportion of coppice forests has decreased over time due to the policy of conversion to high forest. Some 43 percent of forests are classed as degraded and in need of rehabilitation works. The total growing stock is 1.49 billion $\mathrm{m}^{3}$ with degraded forests accounting for 71.95 million $\mathrm{m}^{3}$ or 4.4 percent of the growing stock. The average growing stock is $72.14 \mathrm{~m}^{3}$ per ha varying from less than $5 \mathrm{~m}^{3}$ per ha in degraded forest to $123 \mathrm{~m}^{3}$ per ha in productive high forest. This compares with European and world averages of $105 \mathrm{~m}^{3}$ per ha and $130 \mathrm{~m}^{3}$ per ha. ${ }^{21}$

\section{TABLE 1 FOREST AREA AND GROWING STOCK}

\begin{tabular}{|l|r|r|r|r|r|r|}
\hline & \multicolumn{2}{c}{ Area (million ha) } & \multicolumn{3}{c}{ Growing Stock (million $\left.\mathrm{m}^{3}\right)$} \\
\hline Forest Type & $\begin{array}{r}\text { Productive } \\
\text { Forest }\end{array}$ & $\begin{array}{r}\text { Degraded } \\
\text { Forest }\end{array}$ & Total & $\begin{array}{r}\text { Productive } \\
\text { Forest }\end{array}$ & $\begin{array}{r}\text { Degraded } \\
\text { Forest }\end{array}$ & Total \\
\hline High forest & 11.92 & 7.70 & 19.62 & $1,506.13$ & 33.69 & $1,539.82$ \\
\hline Coppice forest & 0.79 & 1.94 & 2.72 & 60.00 & 11.95 & 71.95 \\
\hline Total & $\mathbf{1 2 . 7 0}$ & $\mathbf{9 . 6 4}$ & $\mathbf{2 2 . 3 4}$ & $\mathbf{1 , 5 6 6 . 1 3}$ & $\mathbf{4 5 . 6 5}$ & $\mathbf{1 , 6 1 1 . 7 7}$ \\
\hline
\end{tabular}

\footnotetext{
19. Forest Inventory Results 2015. Forest management and Planning Department, General Directorate of Forestry, Ministry of Forestry and Water Affairs, Ankara.

20. High forest refers to forests which originate from seed and are managed on a long rotation to produce sawlogs. Coppice is where the forest is regenerated from shoots arising from the cut stumps of harvested trees. Coppicing usually produces many stems per stump, and is usually managed on shorter rotations for firewood or other lower quality products.

21. State of Europe's Forests 2011. Status and Trends in Sustainable Forest Management in Europe. FOREST EUROPE Liaison Unit Oslo.
} 
FIGURE 3 FOREST COVER OF TURKEY

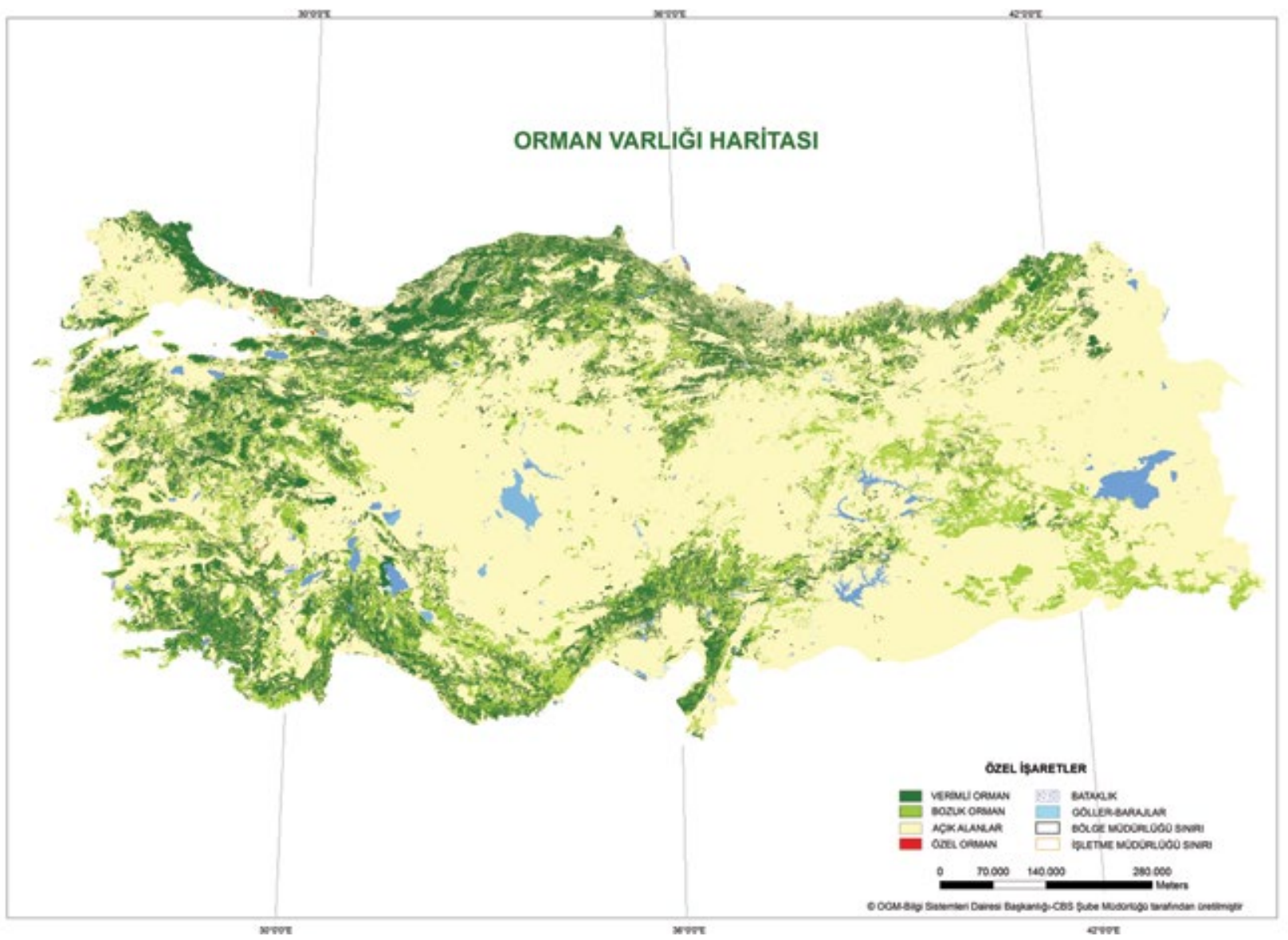

TABLE 2 ANNUAL INCREMENT

\begin{tabular}{|c|c|c|c|}
\hline & \multicolumn{3}{|c|}{ Annual Increment (million $\mathrm{m}^{3}$ ) } \\
\hline Forest Type & $\begin{array}{r}\text { Productive } \\
\text { Forest }\end{array}$ & $\begin{array}{r}\text { Degraded } \\
\text { Forest }\end{array}$ & Total \\
\hline High forest & 42.32 & 1.48 & 43.81 \\
\hline Coppice forest & 1.51 & 0.59 & 2.10 \\
\hline Total & 43.83 & 2.07 & 45.90 \\
\hline Conifers & 29.43 & 1.05 & 30.48 \\
\hline Broadleaves & 14.40 & 1.02 & 15.42 \\
\hline Total & 43.83 & 2.07 & 45.90 \\
\hline
\end{tabular}

The total annual volume increment is estimated as 45.90 million $\mathrm{m}^{3}$, with high forest accounting for 43.81 million $\mathrm{m}^{3}$ or 95 percent (Table 2). Conifers, both in productive and degraded forests, have by far the greatest increment totaling 40.02 million $\mathrm{m}^{3}$. The average annual increment is $2.05 \mathrm{~m}^{3}$ per ha (Table 3). This compares with a European average

\section{TABLE 3 AVERAGE ANNUAL INCREMENT PER HECTARE}

\begin{tabular}{|c|c|c|c|}
\hline \multirow[b]{2}{*}{ Forest Type } & \multicolumn{3}{|c|}{ Annual Increment (million $\mathrm{m}^{3}$ ) } \\
\hline & $\begin{array}{r}\text { Productive } \\
\text { Forest }\end{array}$ & $\begin{array}{r}\text { Degraded } \\
\text { Forest }\end{array}$ & Total \\
\hline High forest & 3.55 & 0.19 & 2.23 \\
\hline Coppice forest & 1.93 & 0.30 & 0.77 \\
\hline Total & 3.45 & 0.21 & 2.05 \\
\hline
\end{tabular}

(excluding Russia Federation) of $5.4 \mathrm{~m}^{3}$ per ha. Where there are favorable growing conditions, fastgrowing plantations can achieve annual growth rates up to $20 \mathrm{~m}^{3}$ per ha. The annual average increment has shown an increasing trend from 1.39 $\mathrm{m}^{3}$ per ha in 1973 to today's value of $2.05 \mathrm{~m}^{3}$ per ha. The annual allowable cut (AAC) is circa 18 - 
20 million $\mathrm{m}^{3}$ or approximately 44 percent of the increment. This compares with a European Union average of 73 percent for fellings as a percentage of increment. The AAC does not include fellings in young stands or extraordinary fellings (windblow, fire, disease outbreak etc.) which typically average 4-5 million $\mathrm{m}^{3}$. Total fellings represent circa 54 percent of annual increment.

Broadleaf forests are prevalent along northern Turkey. Coniferous forests, depending on the species and locations, are found at varying altitudes from sea level to the timber line. Forest formations of the country include species belonging to different floristic regions, namely Irano-Turanion, Mediterranean and Euro-Siberian. Conifers represent 67 percent of the total forest area. The main species are oaks (Quercus spp) (26.3 percent), Brutia pine (25.1 percent), Pinus nigra (19.0 percent), beech (8.5 percent), Scots pine (6.8 percent), juniper (4.3 percent), firs (2.6 percent), and cedar (2.2 percent) as shown in Figure 4.

\section{FIGURE 4 SPECIES PERCENTAGE OF TOTAL FOREST AREA}
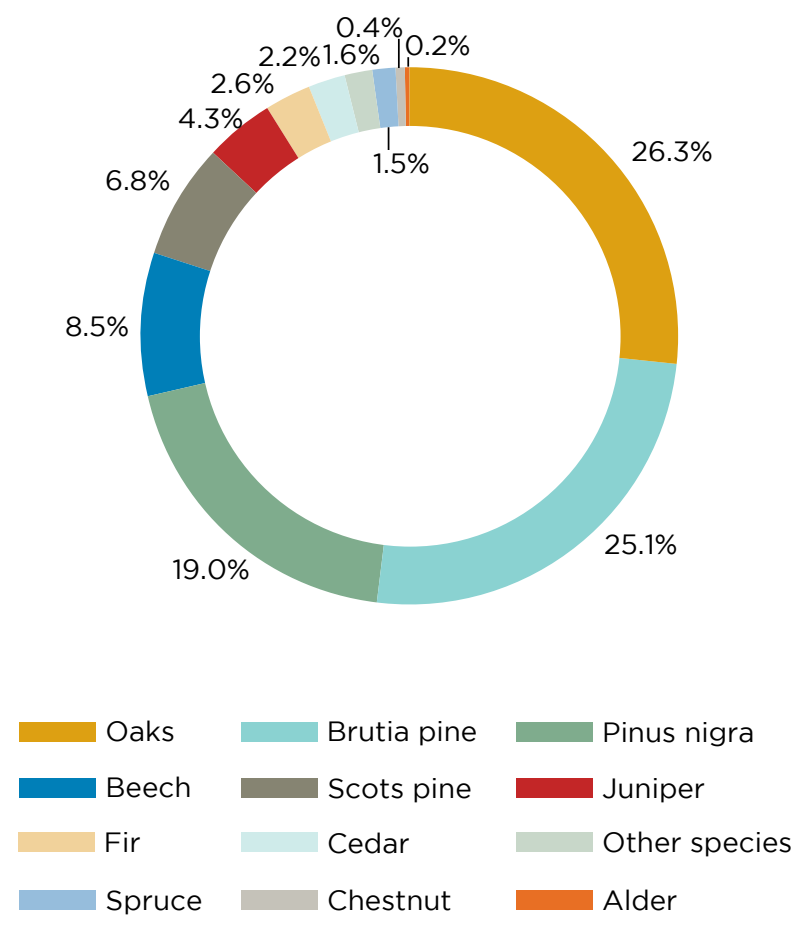

\subsection{The Legislative, Policy and Institutional Framework}

\subsubsection{Forest Policy and Strategy}

The general economic and social development policy in Turkey is defined by the Ministry of Development which, following broad stakeholder consultations, develops the country policy for the most important sectors of the economy including forestry through the National Development Plan.

The main forestry policy documents are the Tenth Development Plan (2014-2018), the National Forestry Program (2004-2023), the Strategic Plan of the Ministry of Forestry and Water Affairs (20132017) and the General Directorate of Forestry's Strategic Plan (2013-2017). These documents address numerous issues ranging from forest protection, to sustainable production of industrial wood and fuel wood to meet domestic demand, non-wood forest products, rehabilitation and reclamation of degraded forest areas, national parks and protected areas, the protection of wildife, supply of ecosystem and social services, and rural development.

The Ministry of Forestry and Water Affairs (MFWA) is responsible for preparation of plans for combating desertification and erosion and carrying out activities concerning protected areas, national parks and hunting. The General Directorate of Forestry (GDF) within the MFWA is responsible for integration of the policy and supervision of the implementation.

The objectives of the National Forestry Program (NFP) are to contribute to: (1) The establishment of appropriate institutional capacities and mechanisms to deal with forestry subjects in a broader perspective through sustainable development; (2) The improvement of adaptation and linkages between forestry and other sectors; (3) The improvement of awareness, interest, participation, support and contributions of community and stakeholders regarding the importance of stable and sustainable development of the country; (4) Strengthen the support for the rehabilitation of multiple-use forests by improving the multi- 


\section{TABLE 4 EXAMPLE OF STRATEGIC PLAN TARGETS - ROAD INFRASTRUCTURE}

\begin{tabular}{|l|r|r|r|r|r|r|r|}
\hline & & & \multicolumn{4}{c|}{ Planned } \\
\hline Indicator & 2011 & 2012 & 2013 & 2014 & 2015 & 2016 & 2017 \\
\hline Road Density (m/ha) & 10.76 & 10.87 & 11.10 & 11.20 & 11.23 & 11.34 & 11.46 \\
\hline Standard Forest Roads $(\mathrm{km})$ & 231,825 & 240,836 & 240,878 & 243,000 & 241,825 & 244,325 & 246,825 \\
\hline
\end{tabular}

functional and participative forest resources management, and improvement of the living standards in the forest villages in or in the vicinity of the forests where poverty and dependency on the forests are the reality; and (5) Strengthen financial support (National and International) for forestry activities.

The GDF's strategic plan (2013-2017) sets out the overall mission which is "To protect forests and forest resources against any type of risks, develop them under an environmentally friendly understanding and manage them as part of the ecosystem integrity and in such a manner which will provide the public with multi-directional sustainable benefits".

The four strategic objectives are to (1) protect the forests and areas qualifying as forests as well as their biodiversity against any kind of biotic and abiotic pests, (2) develop the existing forests, increase their efficiency and expand their area, (3) meet the developing and changing expectations of the public for the goods and services produced by the forests optimally and (4) ensure the institutional development for providing the sustainable forest management, offering faster and higher quality services and attaining the designated strategic objectives.

Under each strategic objective, the plan sets out in detail the basic strategies to be undertaken together with specific targets and performance indicators for each year. Thus under the strategic objective to protect forests there is a target to improve the existing forestry infrastructure and to standardize the road network as effective protection and management is dependent upon the availability of suitable infrastructure while the delivery of services requires that forest roads meet specific standards for their utilization.

For each specific target the unit or department within GDF which is responsible is clearly identified. There are procedures in place for monitoring performance and progress against the targets together with identified annual costs associated with each target and performance indicator. The costs for the targets are met by GDF special Budget (Treasury assistance and own revenues) and the Revolving Fund Budget (sales of forest products and other revenue sources). They do not include staff costs and statutory payments which are included in the general management costs of the GDF. The total cost is 25,784 million TL over the period of the plan of which 12,442 million TL will be financed by the Special Budget and the remaining 13,343 million TL from Revolving funds.

Overall the policy and strategy are well defined and based on an analysis of the national and international context, there are procedures in place to monitor performance against plan and funding sources are identified. The strategic planning process includes specific measures for participation of stakeholders, both external and internal, in line with the provisions of the "General Principles" indicated in Article 5 of the Regulation on the procedures and principles for Strategic Planning.

\subsubsection{Legislation}

Table 5 shows the chronology (starting with the most recent) of the passing of various acts and legal arrangements. 
TABLE 5 HISTORICAL DEVELOPMENT OF FOREST LEGAL AND REGULATORY FRAMEWORK

\begin{tabular}{|c|c|c|}
\hline Year & $\begin{array}{l}\text { Laws and legal } \\
\text { arrangements (national, } \\
\text { regional, global) }\end{array}$ & Topic and issues addressed \\
\hline 1995- present & $\begin{array}{l}\text { UNCED, IPF/IFF, CBD, CCD, } \\
\text { Pan-European Process, } \\
\text { Near East process, C\&I for } \\
\text { SFM etc. } \\
\text { Law No } 4122 \\
\text { Law No } 3800\end{array}$ & $\begin{array}{l}\text { - Taking part in regional and global processes related to forestry } \\
\text { dialogue for sustainable development of society; } \\
\text { - Seeking ways to involve more public interest in forestry, forest } \\
\text { management and nature protection; } \\
\text { - Amendments and/or additions to existing legislation through } \\
\text { incorporating increased public needs and multi-functional } \\
\text { benefits of forest resources. }\end{array}$ \\
\hline 1983-1988 & $\begin{array}{l}\text { Amendments/additions and } \\
\text { changes of forest and forest } \\
\text { related legislation mainly on } \\
\text { Forest Law No } 6831\end{array}$ & $\begin{array}{l}\text { - Increases in forest-based subsidies as in kind and credit basis; } \\
\text { - New arrangements for encouragement of village co-operatives } \\
\text { in private afforestation and private forest establishment; } \\
\text { - Co-operation Programs with agencies other than forestry and } \\
\text { village co-operatives on development efforts for forest villages. }\end{array}$ \\
\hline 1983 & National Parks Law No 2873 & $\begin{array}{l}\text { - Considering the environmental and landscape dimensions of } \\
\text { forests; } \\
\text { - Establishing more natural parks and protected forest areas, } \\
\text { particularly in mountain ecosystems. }\end{array}$ \\
\hline $1969-1973$ & $\begin{array}{l}\text { Forest Village Development } \\
\text { Fund } \\
\text { Law No } 1744\end{array}$ & $\begin{array}{l}\text { - The first Ministry of Forestry established; } \\
\text { - The Forest Village Affairs General Directorate established; } \\
\text { - Special fund for village development developed; } \\
\text { - District level development plans provided for forest villages; } \\
\text { - Mechanisms for more credit and grants to forest villages and } \\
\text { village co-operatives. }\end{array}$ \\
\hline 1956 & Forest Law 6831 & $\begin{array}{l}\text { - Establishing the foundation for today's forestry concept; } \\
\text { - Efficient protection and production mechanisms; } \\
\text { - Multiple management of forest resources; } \\
\text { - Concessions for forest dependent villages and village co- } \\
\text { operatives. }\end{array}$ \\
\hline 1937 & Forest Law 3116 & $\begin{array}{l}\text { - First comprehensive forestry regulation; } \\
\text { - Recognition of the importance/influence of forest dependent } \\
\text { people on good forest management; } \\
\text { - Timber- based forest production and oriented forest practices; } \\
\text { - Setting up scientific and technical based forestry approach. }\end{array}$ \\
\hline 1921-1924 & $\begin{array}{l}\text { Wood cutting Law } \\
\text { Usufruct Law }\end{array}$ & $\begin{array}{l}\text { - Only fuelwood production considered; } \\
\text { - Forestry organization began to grow and develop; } \\
\text { - Regulation on fuelwood utilization. }\end{array}$ \\
\hline 1862-1869 & Forest Status & $\begin{array}{l}\text { - Primitive forest regulation, decisions and commands mainly on } \\
\text { fuelwood utilization from forests; } \\
\text { - Sultanates' wood-based needs; } \\
\text { - Foundation of the first directorate of forestry. }\end{array}$ \\
\hline
\end{tabular}

The country's first forestry decree was enacted in 1920 under the Ottoman Empire and adopted by the Republic of Turkey (1923) which later developed the first Forest Code in 1937. The current main Forest Law was adopted in 1956 and has been amended several times. Provisions concerning forestry are also found in other pieces of principal legislation, such as the laws on nationalization of forests (1945), on maquis (1950), on forest village development (1983), on ranges (1998), on improvement of wild olive trees (1939) on afforestation (1995)22 and on national parks (1983). A major amendment to forest management regulations was adopted in 2008 , and various other pieces of subsidiary legislation are in place, such as those concerning afforestation (2003) and forest cadaster (2004). A more complete list of relevant legislation, regulations and international conventions and processes is provided in Appendices 1 and 2.

The 1982 Constitution of Turkey is a significant source of substantive forestry law. Articles 169

22. Cirelli, M.T. (2013) Forestry Legislation in Azerbaijan, Central Asian Countries and Turkey - Common issues and guidelines for reform. FAO, Rome. 
of the Constitution states that (a) irrespective of ownership, all forests are under control of the State, (b) ownership of the State Forests cannot be transferred and these forests are run by the State, (c) general and/or special amnesty for Forest Offences cannot be arranged, (d) forest borders cannot be reduced except in special circumstances and (e) the State, in order to protect and improve the forests takes necessary precautions and legislates.

An Environment Law was adopted in 1983 and extensively revised in 2006, while a law on biosafety was adopted in 2010. A law on national parks has been in place since 1983. The Terrestrial Hunting Law was adopted in 2003. The law on land reform was adopted in 2005. There are also laws on tourism encouragement (1982) and on the protection of cultural and natural assets (1983).

The GDF enforces the Forest Law and its officers may call on police, gendarmes, village headmen and other law enforcement bodies to assist in the enforcement of forestry legislation. There is no regime of forest guards as is the case in some European countries. Only GDF forest officers may undertake the prosecution of forest offences by writing official reports. Powers granted to them are extensive, including that of entering households without a warrant, if it not possible to immediately obtain one.

The Forest Code is wide ranging and addresses the definition of forests, categories of forest, forest management and protection, forest improvement, development of forest villages, extinguishing of forest fires, forest pastures, penalties and a reforestation fund. It does not address the harvesting of or rights to non-wood forest products and lacks specific provisions around a national forest inventory and sustainable forest management.

Within the framework of Articles 16, 17 and 18 of the Forest Law, the use of forest land for other purposes (transportation, energy, communication, etc.) is allowed. There have been minor changes in Articles 31 and 32 reflecting changes in forest villages and changes to Article 34 to reflect the changed status of some villages following the 2014 Municipal Law. The GDF together with representatives from Ministry of Agriculture and Food and Ministry of Environment have recently initiated work to identify and redress overlapping institutional roles. The Ministry of Food, Agriculture and Livestock claims that the internal and external quarantine services are under its mandate. However, Articles 2 and 7 of Decree-Law No. 645 provide that the Directorate General of Forestry is responsible for establishing the principles for protecting the health of forest plants, for issuing of health certificates and executing forest quarantine services. Protection of the health of forests should be the responsibility of Directorate General of Forestry.

The principal elements of modern the modern forest legislative framework are presented in Figure 5.

\section{FIGURE 5 FOREST REGULATORY FRAMEWORK}

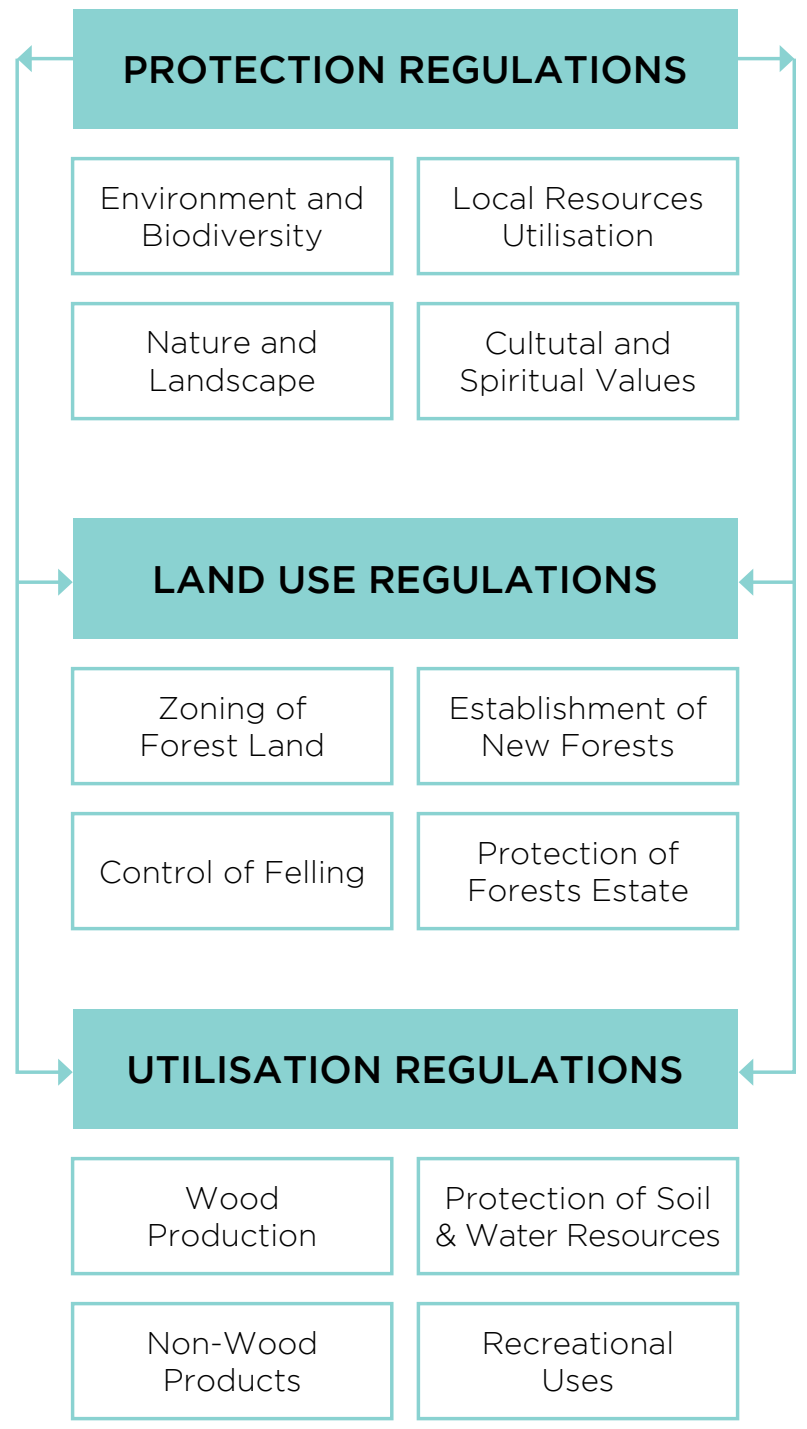




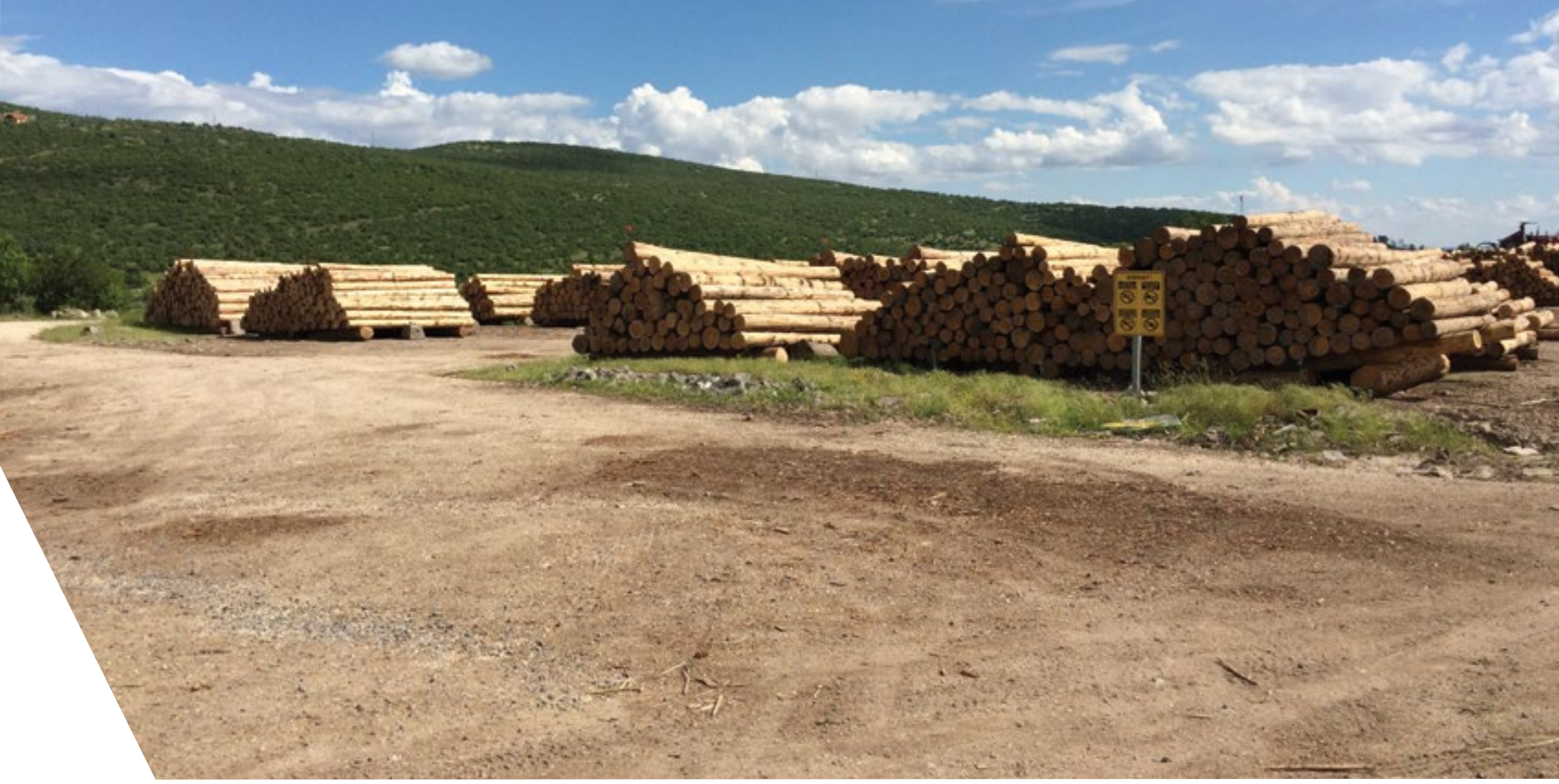

The regulatory framework for forestry in Europe and worldwide is becoming increasingly complex due to a variety of reasons but principally a combination of:

- Global, regional and international agreements that impact on forestry;

- Increased recognition in national forest policies and strategies (NFPSs) of the multiple functions of forests;

- Interaction between forestry and related sectors; and

- Changes in how society perceives and values forests.

In countries where the principal forestry legislation has not been replaced or amended, new developments have come from laws adopted separately, such as legislation on the protection of the environment or nature, rural or mountain area development, subsidies or other forms of support to economic activities. ${ }^{23}$

The main Turkish legislation in forestry was framed over half a century ago and although subject to many amendments in the intervening years suffers from a number of deficiencies. Many of these were recognized in the National Forestry Program (NFP) adopted in 2004 including: (a) lack of uniformity in the text of the Forest Law due to repeated changes and amendments; (b) imprecise definition of forests; (c) private sector largely ignored; (d) insufficient importance given to Non-Wood Forest Products (NWFPs); and, (f) overlap and conflict with other legislation. Other areas where the law can be improved relate to the incorporation of SFM, user rights for NWFPs, methods of sale for wood-based forest products and support for initiatives within the sector.

23. Cirelli, M.T., and Schmithüsen, F., 2000: Trends in Forestry Legislation: Western Europe. FAO Papers online \#10, FAO Development Law Service. (http://www.fao.org). 


\section{FIGURE 6 MINISTRY OF FORESTRY AND WATER AFFAIRS}

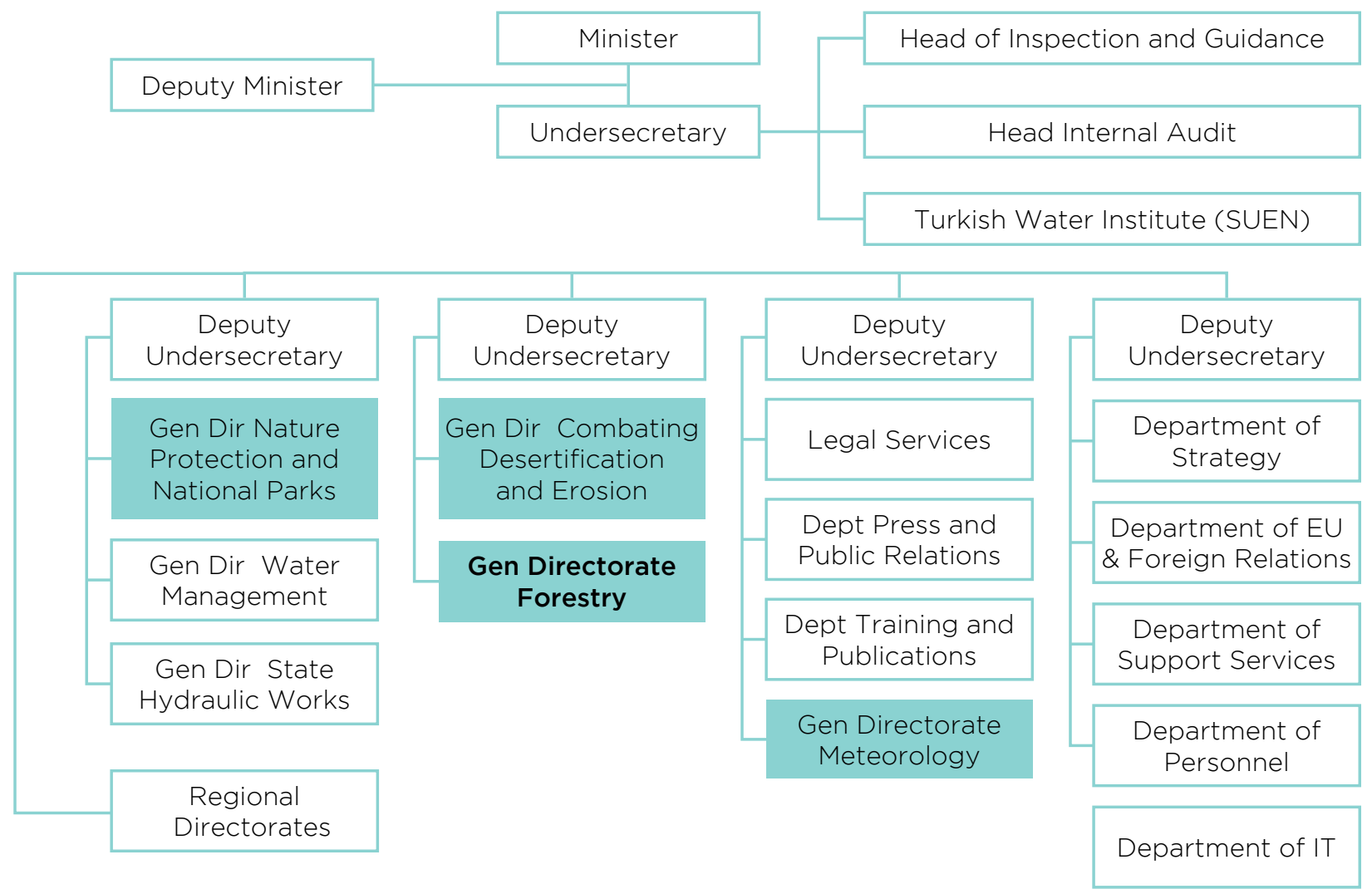

Framework legislation on nature protection, the national biodiversity strategy and action plan still have to be adopted. The draft Nature Protection Law is not in line with the EU acquis. If adopted without implementing legislation, the law would repeal the National Parks Law, causing a legal vacuum. ${ }^{24}$ The recent FAO report on forest legislation ${ }^{25}$ notes that identifying lands to be made perpetually subject to the forestry regime by law may be very difficult, as the evolution of society inevitably brings about needs for other (possibly conflicting) land uses.

\subsubsection{Forest Institutions}

The General Directorate of Forestry (GDF) under the Ministry of Forestry and Water Affairs (MFWA) is the main institution in the sector, as shown in
Figure 6. The GDF is established as a corporate body and is in responsible for almost all sustainable forest management activities, including forest management planning, production and marketing of forest products, the management of forest fires, insects and diseases, forest regeneration and rehabilitation, road construction and maintenance, forest cadaster, urban forests, recreation areas, ecosystem services, reforestation/afforestation, erosion control, watershed management, range improvement and support to forest communities and enforcement.

The structure of the GDF is shown schematically as Figure 7, and the functions and role in Box 1.

\footnotetext{
24. European Commission Turkey Progress Report October 2014.

25. Cirelli, M.T. (2013) Forestry Legislation in Azerbaijan, Central Asian Countries and Turkey - Common issues and guidelines for reform. FAO, Rome.
} 
FIGURE 7 ORGANIZATION STRUCTURE - GENERAL DIRECTORATE OF FORESTRY

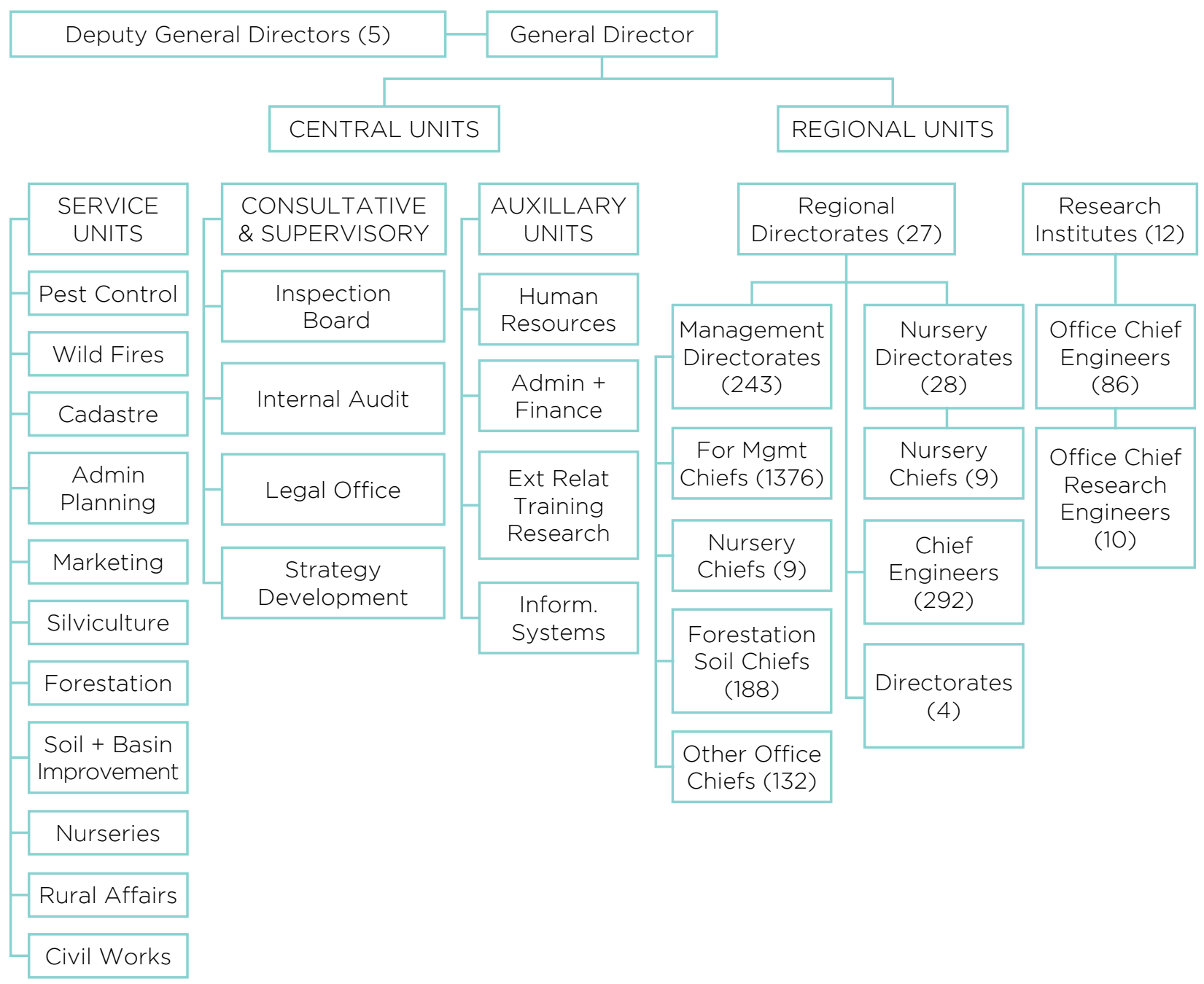

The GDF is a large organization and in 2016 employed 39,028 staff including 17,843 civil servants, 11,954 permanent workers, 8,325 temporary workers with the balance comprising contracted and temporary staff. Some 970 are employed in the headquarters in Ankara. Staff numbers have increased by 18.3 percent since 2007 or at an annual rate of 2.6 percent. The GDF is organized along classic forestry organizational lines with a headquarters comprising service, consultative / supervisory and auxiliary units and Regional Directorates (28) and Research Institutes (12) all reporting to the headquarters. Three of the Research Institutes address national issues (a) poplars and fast growing species, (b) tree and seed improvement and (c) forest soil and ecology. The remaining nine operate at the regional level. Under the Regional Directorates there are a total of 245 Management Directorates or Forest Districts and below these 1,419 Offices of Forest Management Chiefs or Forests and 156 Offices dealing with forestation and soil preservation and 310 Offices of other types of chiefs connected to the Forest Districts. Nurseries are regionally based within the Regional Directorates. 


\section{BOX 1: ROLE OF GDF}

To manage forest resources together with their flora and fauna in an ecologically integrated fashion by taking into account their ecological (climate change, water, recreational etc.), economic, social and cultural values;

To plan forest resources in a participatory and multi-purpose approach, to protect them against any illegal interventions, natural disasters and fires; to combat invasive pests,

To carry out and develop forestry quarantine services; to increase forest area and services provided from forests; to restore and rehabilitate forests and to ensure silvicultural maintenance and regeneration of forests,

To designate recreational areas, urban forests, research forests and arboretum, protective areas for biological diversity, model and protective forests and to conserve and sustainably manage these areas,

To carry out activities such as afforestation and erosion control, rehabilitation of rangelands, combating desertification, floods and avalanche control in any area within forests and outside forests; to develop and implement integrated watershed projects,

To grow seeds, seedlings, shrubs and forest plants, undertake plant health activities, establish and manage permanent and/or temporary nurseries,

To carry out research and development, inventory, projects related to its services, implement relevant projects and disseminate the outcomes nationally and internationally,

To define technical and administrative principles related to issues within its authority and establish laboratories regarding its field of activities.

\section{TABLE 6 EMPLOYMENT IN GDF}

\begin{tabular}{|c|c|c|c|c|c|c|}
\hline Year & $\begin{array}{r}\text { Civil } \\
\text { Servants }\end{array}$ & $\begin{array}{r}\text { Contracted } \\
\text { Staff }\end{array}$ & $\begin{array}{r}\text { Permanenet } \\
\text { Workers }\end{array}$ & $\begin{array}{r}\text { Temporary } \\
\text { Workers }\end{array}$ & $\begin{array}{r}\text { Temporary } \\
\text { Staff }\end{array}$ & Total \\
\hline 2007 & 15,014 & 873 & 14,117 & 2,980 & - & 32,984 \\
\hline 2009 & 14,910 & 868 & 13,862 & 3,201 & - & 32,841 \\
\hline 2011 & 17,499 & 164 & 15,584 & 5,292 & 528 & 39,067 \\
\hline 2013 & 18,525 & 168 & 14,270 & 7,214 & 481 & 40,658 \\
\hline 2014 & 18,132 & 164 & 14,279 & 8,445 & 658 & 41,678 \\
\hline 2015 & 18,073 & 161 & 13,413 & 8,537 & 733 & 40,917 \\
\hline 2016 & 17,843 & 165 & 11,954 & 8,325 & 741 & 39,028 \\
\hline
\end{tabular}


The MFWA also includes the General Directorate of Combating Desertification and Erosion (GDCDE), the General Directorate of Nature Conservation and National Parks (GDNCNP), the General Directorate of Water Management (GDWM) and the General Directorate of Meteorology (GDM). The GDCDE prior to the reorganization in 2011 was called the General Directorate of Afforestation and Erosion and undertook afforestation and erosion control activities. Now the GDCDE is responsible for creating and monitoring plans and projects to combat desertification and erosion; controlling avalanche, landslide and flood; integrated basin rehabilitation as well as making national and regional plans, and determining policies and strategies for improving water basins on the basis of basin integrity in order to conserve soil and to improve natural resources. The GDCDE works mainly in forestry related fields and supports the sustainable development, expansion of forests and rehabilitation of degraded forest and other lands throughout the country. It has a headquarters with four main departments and 20 branch divisions. The GDCDE has no budget for remedial works apart from specific projects financed by exceptional sources other than MWFA. Thus the rehabilitation of degraded forest lands and other remedial works are paid and implemented by GDF.

The GDNCNP has responsibility for the planning, arrangement and improvement of national parks, natural parks, natural monuments and, protected wildlife reserves as well as preservation of plant and animal species of the country. It has a headquarters with seven departments and 41 branch divisions responsible for national parks, nature protection, fragile areas, wildlife, hunting management and biodiversity and ten regionally based National Park Directorates. Countrywide the MFWA has 15 regional Directorates, 81 provincial branch directorates, 10 national park directorates and 105 District offices. It has a staff of 1,784 of which 233 are administrative, 578 technical and 973 classed as support staff dealing with the duties of the GDNCNP. A significant proportion of GDNCNP activities takes place on forested land and it interacts closely with the GDF.
Specific institutional arrangements for private afforestation includes the "Division for Private Afforestation", "Division for Private Afforestation Permits" "Credits and Supervision Division" under the Afforestation Department of the GDF. These units are in charge of central level planning, coordination, monitoring, assessment and reporting of the private afforestation implementation and achievements.

\section{State Forest Institutions Role and Organization}

The functions of the state in relation to forestry fall under four main headings:

1. Regulatory - formulating forest policy and drafting the related legal acts necessary for its implementation (preferably in an open process involving stakeholders and interest groups);

2. Supervisory - enforcement and control over compliance with the law and the related statutory acts in all forests irrespective of the form of ownership;

3. Support - actions undertaken by the state and its institutions and, or with the financial support from the state to ensure maintenance of the forest's long-term functions and promote the development of the private sector; and

4. Ownership - management of the state-owned forest property in a manner to retain and increase its value and yield profit to its owner, i.e. the state, while providing for the realization of the forest's ecological and social functions as approved by society.

The World Bank review ${ }^{26}$ of state forest institutions drew attention to the wide range of organizational models including integrated state forest and management administrations, such as in Turkey, which retain responsibilities for all functions, including the establishment of policy and legislation, forest management, roundwood sales, and forest inspection with funding from the state budget. Revenues from roundwood sales and from other services are transferred back to the state. However, increasingly common is the establishment of separate forest administration and forest management organizations. The forest administration has responsibility for policy,

26. World Bank (2005). Forest Institutions in Transition: Experiences and Lessons from Eastern Europe. Washington, DC. 


\section{FIGURE 8 BEST PRACTICE FOREST INSTITUTIONS}

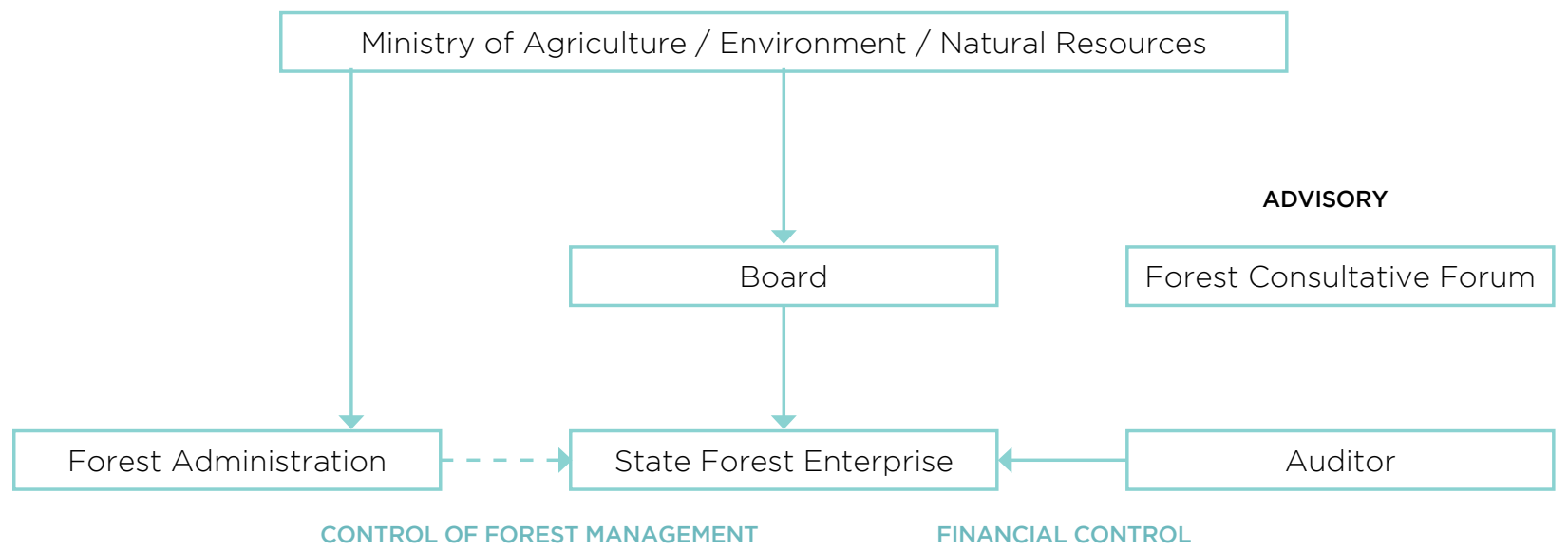

legislation, regulation and some public goods functions, which are all financed by the state budget. A separate state forest management organization is responsible for timber sales and forest management activities and may depend on sales revenues for its funding. In other countries, a state forest administration retains responsibility primarily for planning, guiding and monitoring forest management in state and private forests as well as for other public functions such as extension services and research, while harvesting and/or forest management is carried out by the private sector under concession arrangements.

Institutional arrangements that have proved successful in one country can create both positive and negative impacts for other countries. Understanding the country context (political, economic, cultural, social and forests) is vitally important. The separation of supervisory and ownership is seen as a safeguard against overexploitation of the forest resource and its misuse. However merely separating the functions does not of itself guarantee an improved result.
Elements identified as being part of best practice successful institutional reforms in forest sector include ${ }^{27}$ :

1. Remove direct links (administrative, financial) between entities responsible for public functions and state forest management in order to:

a. Eliminate potential conflicts of interest; and

b. Ensure independence, transparency and neutrality of public forest administration.

2. Increase productivity and efficiency through:

a. Establishing an independent budget for the entity managing state forests with well-defined obligations towards state budget; and

b. Development of salary schemes which are based on staff performance to reduce incentive for corruption.

3. Ensure effective operational control over State Forest Enterprise:

a. Require transparent budget procedures and accounting systems matching corporate standards;

27. Institutional Changes in Forest Management in Countries with Transition Economies: Problems and Solutions. Moscow, Russia 25 February 2003 Workshop Proceedings, PROFOR, World Bank. 
b. Assign responsibility for controlling forest harvesting and management to state forest administration; and

c. Arrange financial auditing through accredited third party auditors.

4. Ensure strategic control over state forest management:

a. Establish a management board to supervise the activities of the entity managing state forests, including representatives from government, as well as professionals with qualifications in forestry, environmental conservation and corporate management

A simplified organogram showing the split between supervisory and ownership functions is provided in Figure 8.

\section{State Forest Institutions - Benchmarking}

The GDF is a large centrally controlled organization that essentially sets its own targets, monitors itself in terms of performance, audits itself through an internal audit and reports on itself to Government and the public. It does not benchmark itself against other state forest organizations. The World Bank report noted that benchmarking based on financial data is relatively straightforward, and is used by some state forest enterprises to establish performance based on financial statistics - turnover, profit, earnings before interest and tax $(E B I T)$, return on investment $(R O I)$.

A simple benchmarking exercise comparing the GDF 2014 outturn with state owned forest organizations in Ireland, Poland and Romania shows that the GDF is the only loss making (loss is equivalent to the Special budget contribution) entity and the only organization not paying the state a dividend for the use of the forest asset. While the business ethos across these four organizations differ with the GDF having a more social remit, the benchmarking does show that the GDF forest increment, growing stock and harvested volume per employee are on average less than their counterparts. In contrast GDF has the highest forest area per employee.

\subsubsection{Stakeholders}

The inhabitants of the settlements and communities, in and/or near the forest areas, which are generally called "forest villages" (approx. population of 7.08 million forest dependent people) are the most affected beneficiary stakeholders in the forestry sector in Turkey.

\section{TABLE 7 BENCHMARKING}

\begin{tabular}{|c|c|c|c|c|}
\hline Description & $\begin{array}{r}\text { Coillte Ireland } \\
2014\end{array}$ & $\begin{array}{r}\text { Lasy Panstwowe } \\
\text { Poland } 2013\end{array}$ & $\begin{array}{r}\text { RomSilva } \\
\text { Romania } 2013\end{array}$ & $\begin{array}{r}\text { GDF Turkey } \\
2014\end{array}$ \\
\hline Turnover per employee (US\$) & 354,888 & 80,894 & 19,404 & 27,299 \\
\hline Timber revenue per employee (US\$) & 68,944 & 71,172 & 14,958 & 19,362 \\
\hline Timber revenue per hectare (US\$) & 161 & 243 & 110 & 37 \\
\hline Profit/loss per employee (US $\$$ ) & 45,641 & 8,985 & 1,361 & $-12,056$ \\
\hline Profit/loss per hectare (US\$) & 106 & 31 & 8 & -23 \\
\hline Forest tax/dividend (US\$) & $4,320,000$ & $45,191,175$ & $3,969,095$ & \\
\hline Forest tax/dividend per hectare (US\$) & 11.10 & 6.21 & 1.23 & \\
\hline Forest area per employee (ha) & 429 & 293 & 177 & 520 \\
\hline Harvested volume per employee (m3) & 2,775 & 1,421 & 526 & 528 \\
\hline Growing stock per employee (m3) & 67,512 & 72,321 & 77,164 & 35,857 \\
\hline Increment per employee (m3) & 5,184 & 3,730 & 992 & 1,012 \\
\hline Protected are per employee (ha) & 176 & 113 & 57 & 48 \\
\hline
\end{tabular}


TABLE 8 FOREST CADASTRE COVERAGE

\begin{tabular}{|c|c|c|c|c|c|c|c|}
\hline \multirow[b]{2}{*}{ Indicator } & \multirow[b]{2}{*}{2011} & \multirow[b]{2}{*}{2012} & \multirow[b]{2}{*}{2013} & \multirow[b]{2}{*}{2014} & \multirow[b]{2}{*}{2015} & \multicolumn{2}{|c|}{ Target } \\
\hline & & & & & & 2016 & 2017 \\
\hline $\begin{array}{l}\text { Cumulative area where cadaste } \\
\text { concluded ('OOOha) }\end{array}$ & 18,860 & 19,117 & 19,592 & 20,775 & 21,850 & 23,000 & - \\
\hline $\begin{array}{l}\text { Cumulative area where registration } \\
\text { concluded ('OOOha) }\end{array}$ & 12,281 & 16,250 & 16,750 & 16,950 & 17,800 & 18,860 & 20,100 \\
\hline
\end{tabular}

The largest stakeholder in the forest sector is the Central Union of Forest Villagers Cooperative (ORKOOP) with 2,493 affiliated cooperatives and 318,005 members throughout the country of which 1,448 and 193,255 are forestry based respectively. The Chamber of Forest Engineers with 13 regional branches and over 14,000 members is a representative body focusing on the problems and issues facing the forestry profession and its members. The Chamber provides facilities for occupational training of foresters and makes recommendations on forestry practices of the state forestry service.

There are also unions of civil servants and the Unions of Forest Workers as affiliated branches in the forestry sector under the related country level unions and confederations. The worker's unions represent the rights of permanent and temporary forest workers of which there are an estimated 25,000. The Forest Products Exporters, Importers and Manufacturers Association (TORiD) represents the interests of the forest industry. There are a number of NGOs active in the sector including the TEMA Foundation, Foundation for Protection of Natural Life (DHKV), Foundation for Turkey's Nature Protection (TTKD), Turkey Foresters Community (TOD), Association of Green Turkey Foresters (AGTF) and the Nature Protection Centre (NPC).

\subsubsection{Forest Cadaster}

Forestry cadaster covers operations and procedures to establish sound forest borders, taking on board any forest restrictions or cadastral procedures previously imposed or through newly enacted laws and to procure registration for those areas that are excluded from the forest area or where the borders are finalized, under Article 2 of the Forestry Law. ${ }^{28}$ Once the forest cadaster and physical application are completed, problems arising from both the registration of Land Registry and Cadaster Directorate General and immovable properties remaining within forest boundaries are resolved.

Disputes between DGF and citizens concerning the ownership and use of areas restricted as forest as a result of forest cadaster have decreased. While the forest cadaster has been going on for many years, the introduction and use of satellite imagery, aerial photography and geographical information systems has both helped in defining boundaries in a fast and sound manner as well as in the resolution of disputes. At the end of 2016 the forest cadaster has been completed for circa 23 million ha and the registration for circa 18.86 million ha.

\subsection{Forest Monitoring, Evaluation and Research}

\subsubsection{Forest Management}

Management planning dates back to 1917 when the first management plan was prepared by a team of Turkish and Australian engineers. Management plans covering the entire national forests were completed between 1963 and 1972 and from then onwards management plans have been updated periodically. While the focus of the earlier management plans was primarily on timber production, current management plans are a balance of ecological, economic, social and cultural functions of forests subject to the understanding of ecosystem based functional planning. Each

28. Article $2 b$ defines those areas which may be removed from the forest cadastre. 


\section{FIGURE 9 FOREST MANAGEMENT PLANNING PROCESS}

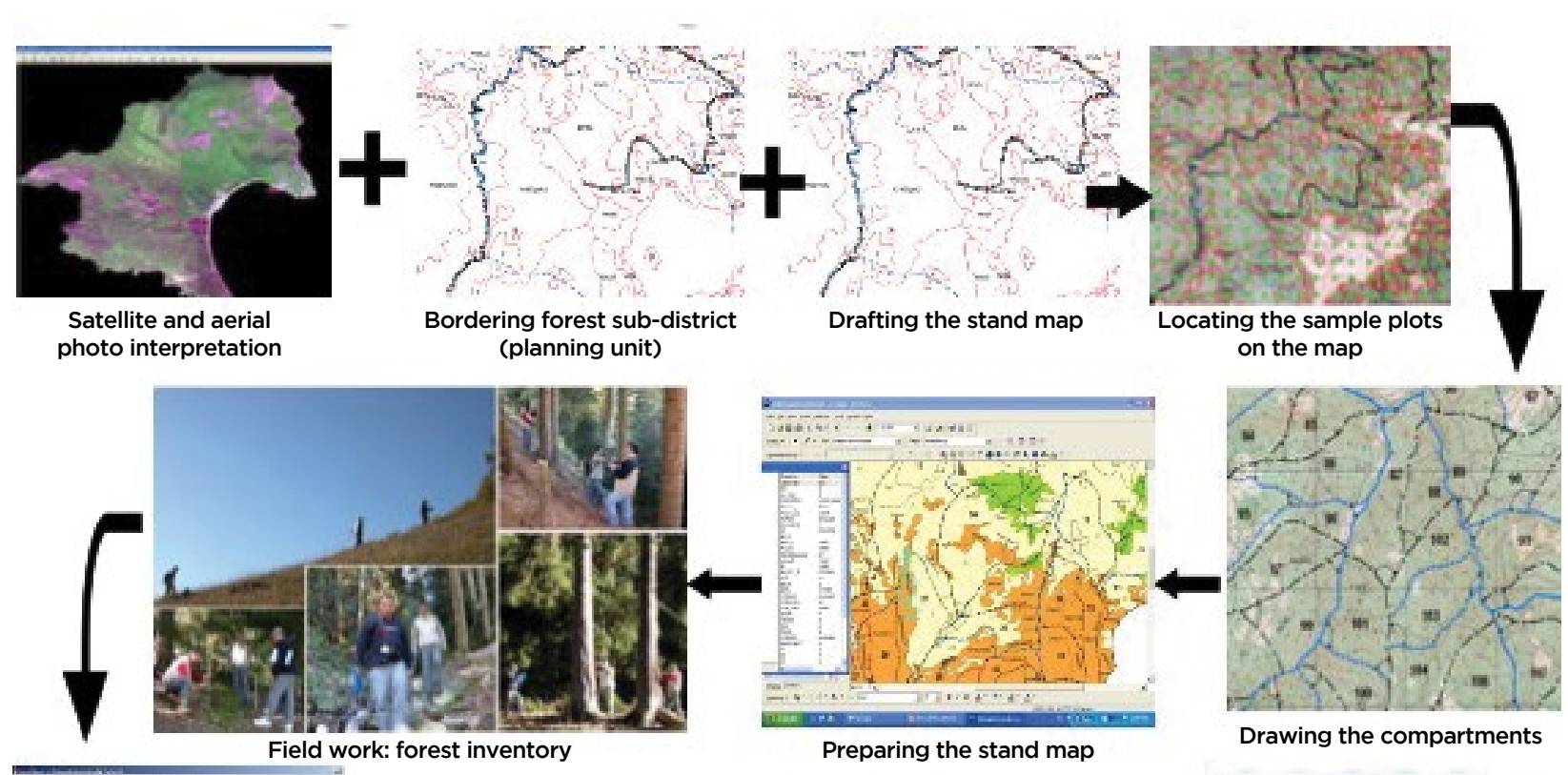

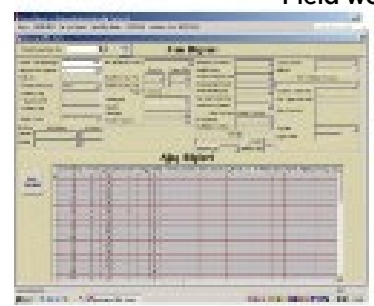

Data entry and evaluation

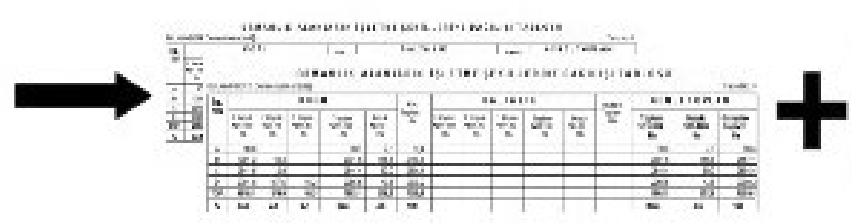

Creating the final report and tables

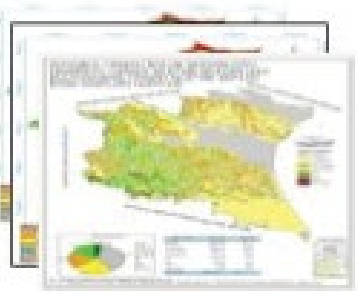

Thematic Maps plan identifies the growing stock in forest areas, volumes and areas for roundwood and Non Wood Forest Product (NWFP) harvesting, water resources protection, erosion control, rehabilitation, afforestation and pasture. Functional forestry management plans were initiated in 2005 and are gradually being rolled out across the GDF forest estate. Figure 9 describes the current management planning process.

According to Articles 26, 46 and 51 of the Forest Law, all forests are required to have management plans. Forest management plans are prepared and implemented in GDF at the level of the individual Forestry Management Chief Office, which is the smallest management unit, for a term of $10-20$ years. Management planning is undertaken by Forestry Management Chief Offices, which are now regionally based, and specialized private management teams. This planning process is well documented including procedures for plot sampling and their layout.

A significant portion of Turkey's very rich biodiversity enjoying global significance is located in forest areas and the preservation and improvement of this biodiversity constitutes one of the fundamental conditions for sustainable management of the forests. The Forest Management and Planning Department within GDF has recently started to integrate biological diversity into forest management plans. In collaboration with universities, research institutes and NGOs, model plans had been completed on an estimated 909,557 ha to the end of 2016. 
TABLE 9 FUNCTIONAL FOREST MANAGEMENT PLANS

\begin{tabular}{|l|r|r|r|r|r|r|r|}
\hline & & & & Target \\
\hline Indicator & 2011 & 2012 & 2013 & 2014 & 2015 & 2016 & 2017 \\
\hline Functional Forest Management Plans ('OOO ha) & 9,873 & 10,779 & 13.780 & 16.644 & 19,658 & 21,420 & 22,500 \\
\hline
\end{tabular}

Related public institutions, NGOs, educational institutions, municipalities, forest-related trade organizations and co-operatives are notified officially a year in advance before the commencement of management planning in the particular forest area. Information is provided on the general objectives of the management plan to be made in the district and also includes questions on the expectations and demands, investment programs, if any, and how to interact them with the forests. There is opportunity for stakeholder involvement during the data field inventory collection phase. Management plans are not subject to any period of public consultation before they are approved internally at headquarter level within GDF. The related unit within the headquarters supervises the preparation of forest management plans.

The management plans for private forests can either be prepared by the GDF or by forest engineers in the private sector approved by the Chamber of Forest Engineers. The private FMPs are approved by GDF.

\subsubsection{National Forest Inventory}

National forest inventories based on statistical sampling methods began in the early part of the twentieth century but are now the norm with the majority of European countries undertaking samplebased National Forest Inventories (NFIs). While the primary purpose of the original NFIs was to provide accurate information on growing stock and wood volumes for industry and investment planning, in more recent times the scope of NFIs has been extended to include information on biodiversity, environmental services, forest carbon, forest health, naturalness and non-timber attributes.

Turkey does not have a National Forest Inventory and relies on the amalgamation of information from forest management plans to provide data on forest resources at a national level for policy, planning and for data to comply with its international reporting commitments. National forest policy requires accurate, timely and comprehensive information. Turkey started national forest inventory work in 2016 and intends to complete forest inventory within the next three years.

The GDF did undertake a pilot NFI project in 2009 which focused on the initial inventory design and methodology and this could be used as the starting point for any future NFI. The purpose of the NFI would be to record and assess the extent and nature of Turkey's forests, both public and private, in a timely, accurate and reproducible manner to enable the sustainable development of the country's forest resource. Reliable, current and consistent information is required to inform domestic forest policy, to support forest research and fulfil national and international reporting commitments.

\subsubsection{Forest Research, Evaluation and Technology}

The Forestry Research Master Plan (FRMP) is the basic instrument for the organization and planning of forest research projects / studies. The first (FRMP) for 1995-1998 was revised in 1999 for the period 2000-2005.

Research proposals for the various disciplines/ branches and field units of the GDF are collated and evaluated on an annual basis through specific meetings as for example Technical Council, Expert Working Groups from related branches of the forestry sector and representatives from the Ministry of Development, Scientific and Technology Research Foundation of Turkey (TUBITAK) etc.

Forestry research activities are carried out by the 12 forestry research institute directorates, of which three serve on a nationwide basis and nine serve on a regional basis as well as by the forestry faculties, other universities and NGOs. 
As of end-2016, there were 230 ongoing research projects including 33 new projects. While interim results have been obtained from 5 of these, 42 projects have been completed and 25 projects were started to be implemented.

All forestry related research studies are funded by the annual budget of the GDF with limited funds for specific research projects allocated by the Scientific and Technological Research Council of Turkey (TUBITAK) and the Ministry of Development.

Areas of recent research include protection, development and expansion of natural forests, development of forestation, wood and nonwood forest products, pasture improvement, improvement of agro-forestry and silva-pastoral systems. Under the Strategic Plan, research projects are being implemented in the areas of tree improvement, erosion control, pasture improvement, bio-diversity and social forestry as well as in other subjects.

The GDF Strategic Plan recognizes that there is inadequate information and ongoing research on the effects of climate change and air pollution on forests and that the adverse effects of climate change in particular in the future is likely to increase.
It will be important to update the FRMP to address climate change and to undertake appropriate research and studies if suitable strategies and measures are to be developed.

\subsection{Forest Management Activities}

\subsubsection{General}

Forests are divided into compartments along natural lines, and are regulated and managed by the forest operation chief's offices. The majority (98 percent) of state owned forests are managed based on the age class forest management system. There are also some uneven-aged forests which are managed according to "diameter class" forest management method and which consist mainly of firs (Abies spp). The existing practice is to convert coppice forests (12 percent) to high forests.

\subsubsection{Forest Protection}

Approximately 12.5 million ha of the 22.34 million ha national forest estate is located in regions highly sensitive to wild fires. Over the period 2000-2013 inclusive, some 139,296 ha were burned with an average of 4.5 ha damaged per fire. The factors affecting fire behavior include meteorology, tree

\section{FIGURE 10 FOREST FIRES - AREA BURNED BY YEAR}

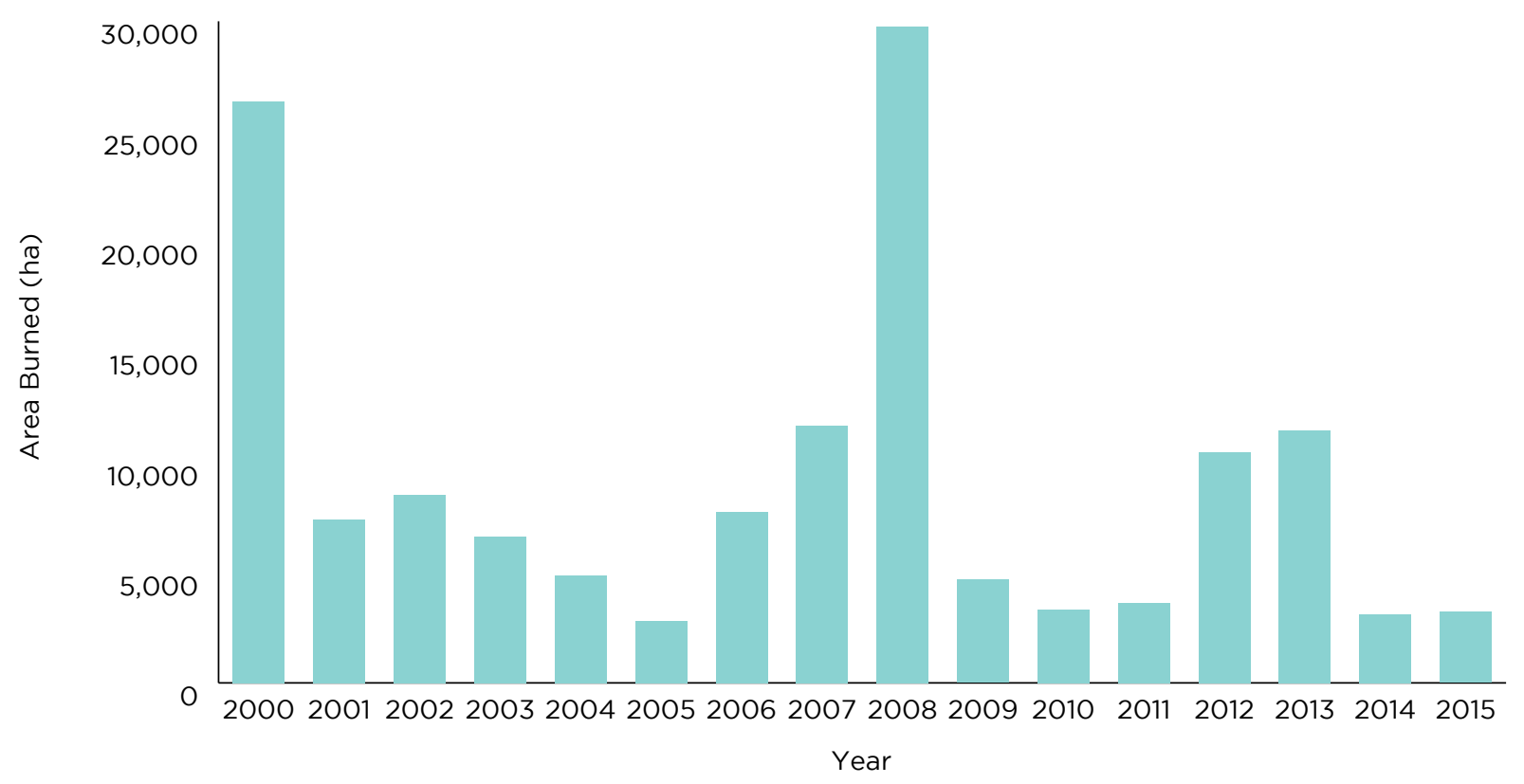


species, fuel load, density, stacking method and topography. Very successful results have been achieved in combating fires in recent years with only 3,218 ha of forest burned in 2,150 fires in 2015 and 3,117 ha of forest burned in 2,149 fires in 2014. Despite the extreme weather conditions in 2016, 9,156 ha of forest area was affected from 3,188 fires. In 2016, some 10 percent of fires were due to natural causes, 5 percent were intentional, 31 percent were due to negligence and the cause of the remaining 54 percent is unknown.

Pursuant to Article 69 of Forest Law, men aged between 18 and 50 must participate in fire control and extinguishing efforts in the surrounding villages and towns. The administration (GDF) must provide transport or reimburse the cost of such acts and pay compensation in case of injury or death. Except in specified areas, starting fires in forests, or burning any vegetation within $4 \mathrm{~km}$ of the boundaries of forests is prohibited. During times of very high risk of fire, the highest civilian authorities in the region may restrict or suspend access to forests or any activities in forests upon request of the forestry administration (GDF).

There are three elements to GDF's fire strategy: (a) prevention (education, awareness raising), (b) extinguishing (early warning, rapid and effective intervention) and (c) rehabilitation (rapid reforestation of burnt areas).

The GDF undertake a range of preventative measures including public awareness campaigns, preparation of fire action plans, enhancement of early warning and decision support systems, controlled burning to mitigate risk, development of fire risk models, construction of fire prevention facilities and regular training delivery.

Turkey's forests are subject to attack by circa 50 harmful insects. The most important of these are bark-cambium and wood beetles (Ips sexdentatus, Ips typographus and Dendroctonus micans) (Tomicus piniperda, Tomicus minor, Orthotomicus tridentatus, Orthotomicus erasus) pests attacking leaves (Diprion pini, Thaumetopoea pityocampa, Lymantria dispar, Acleris undulana) and insects attacking sprouts and shoots (Rhyacionia buoliana, Dryocosmus kuriphilus). Pest infestations vary depending on prevailing soil, climatic and environmental conditions and can lead to substantial losses. Extraordinary (sanitary) fellings average between 300-400,000 $\mathrm{m}^{3}$ annually but can be in excess of 1 million $\mathrm{m}^{3}$ in cases of serious outbreaks.

FIGURE 11 FOREST AREA TREATED AGAINST PESTS

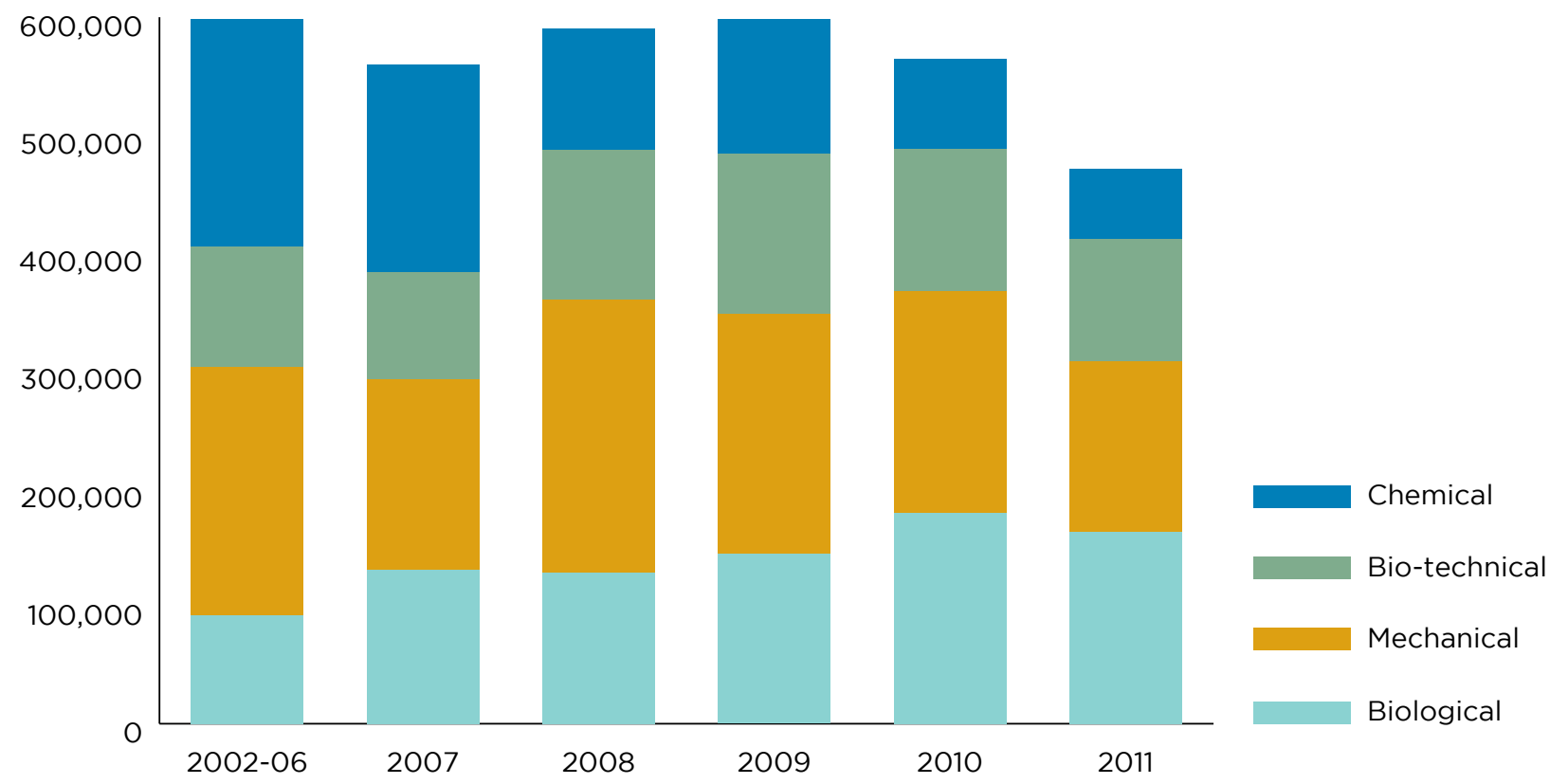


FIGURE 12 ILLEGAL HARVESTING (M³) BY YEAR, 2000 - 2016

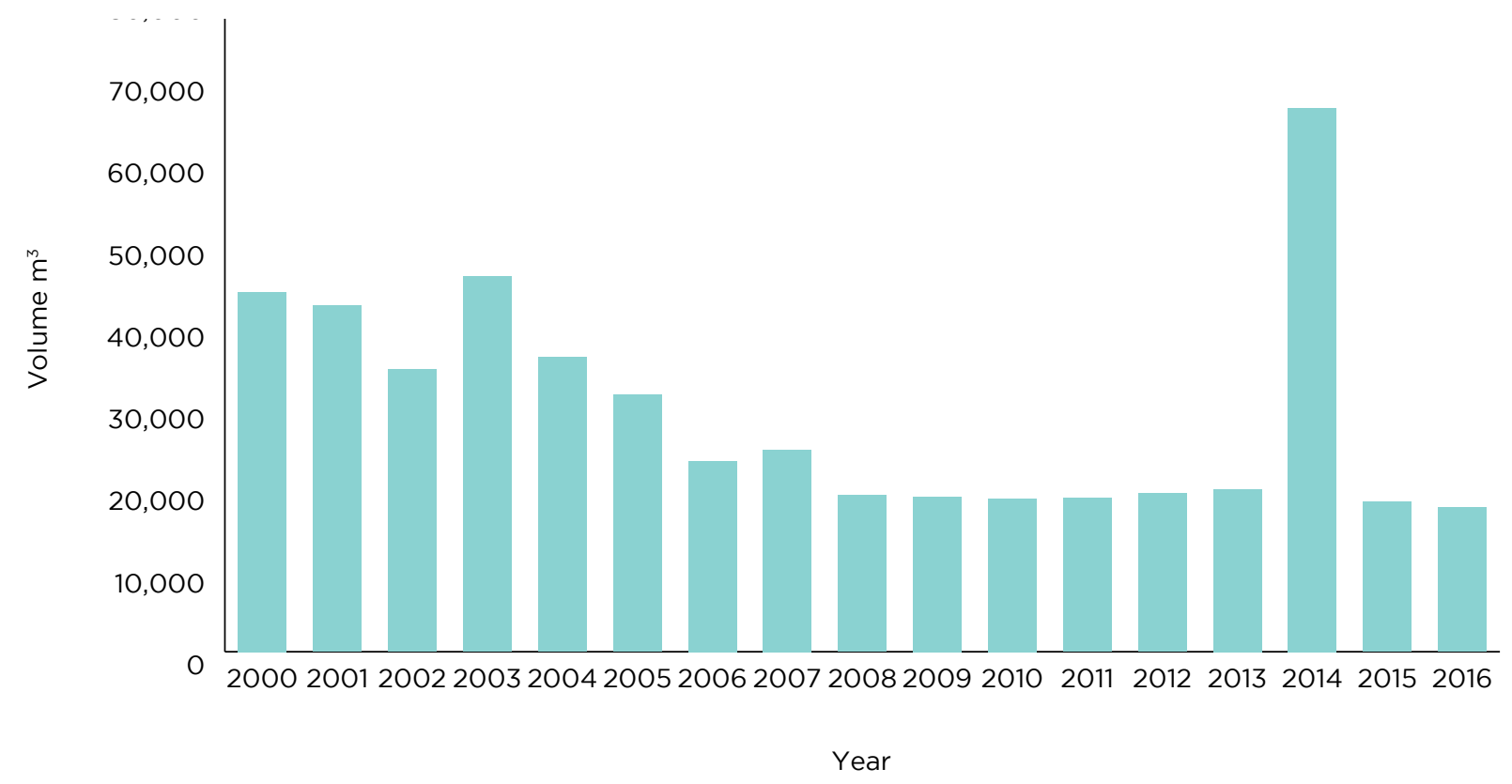

Between 500,000 to 600,000 ha of forests are treated against pests each year using a combination of chemical, mechanical, bio-technical (pheromones) and biological control measures (Figure 11). Since 2002 the emphasis has been on the more widespread use of biological control measures and a reduction in chemical treatments. Currently about 500,000 beneficial/predator insects are grown under laboratory conditions for use as biological control agents. In addition, some 50,000 birds' nests are erected and 150 ants' nests relocated annually. The aim is to reduce dependence on chemical control measures to 1.25 percent by 2017.

While measures against pests are well organized and a positive balance has been ensured in the health condition of forests, forests are increasingly coming under threat from pests coming in with imported products. These can occur on either imported packaging material or imported wood and wood products. The Ministry of Food, Agriculture and Livestock (MFAL) is responsible for preventing the entry of alien invasive organisms and setting up appropriate quarantine measures. However, the insufficiency of quarantine inspections conducted by agricultural engineers on forest plants and plant products has led to the detection of new alien invasive organisms in national forests. In this framework, through the Forest Plants, Seeds and Forest Plant Products imported during the last 10 years, pests such as Ips typographus (spruce bark beetle), Cylindracladium buxicola (boxwood blight disease), Dryocosmus kuriphilis (chestnut gall wasp2014), Pristiphora abietina (small spruce sawfly), Leptoglosus occidentalis (conifer seed bug) and Anoplophora chinensis (citrus long-horned beetle) have entered the country. A phytosanitary certificate is required for timber not treated in the country, but not for reconstituted wood products, plywood, laminated veneer lumber or veneer. Imported softwood logs must be debarked and hardwood logs fumigated.

Illegal harvesting is at a very low level and shows a decreasing trend over time (Figure 12). According to current official statistics about $20,000 \mathrm{~m}^{3}$ are illegally harvested annually with the number of incidents (crimes) varying between 3,000 to 4,000 averaging $5 \mathrm{~m}^{3}$ per incident. The majority of this volume is fuelwood at a local level and there is no evidence to suggest organized illegal harvesting. The illegal volume equates to less than 0.1 percent of the annual allowable cut or approximately 0.05 percent of annual increment. 


\section{FIGURE 13 OBSERVATION AREA INSTALLATION POINTS IN ICP FOREST MEMBER COUNTRIES}

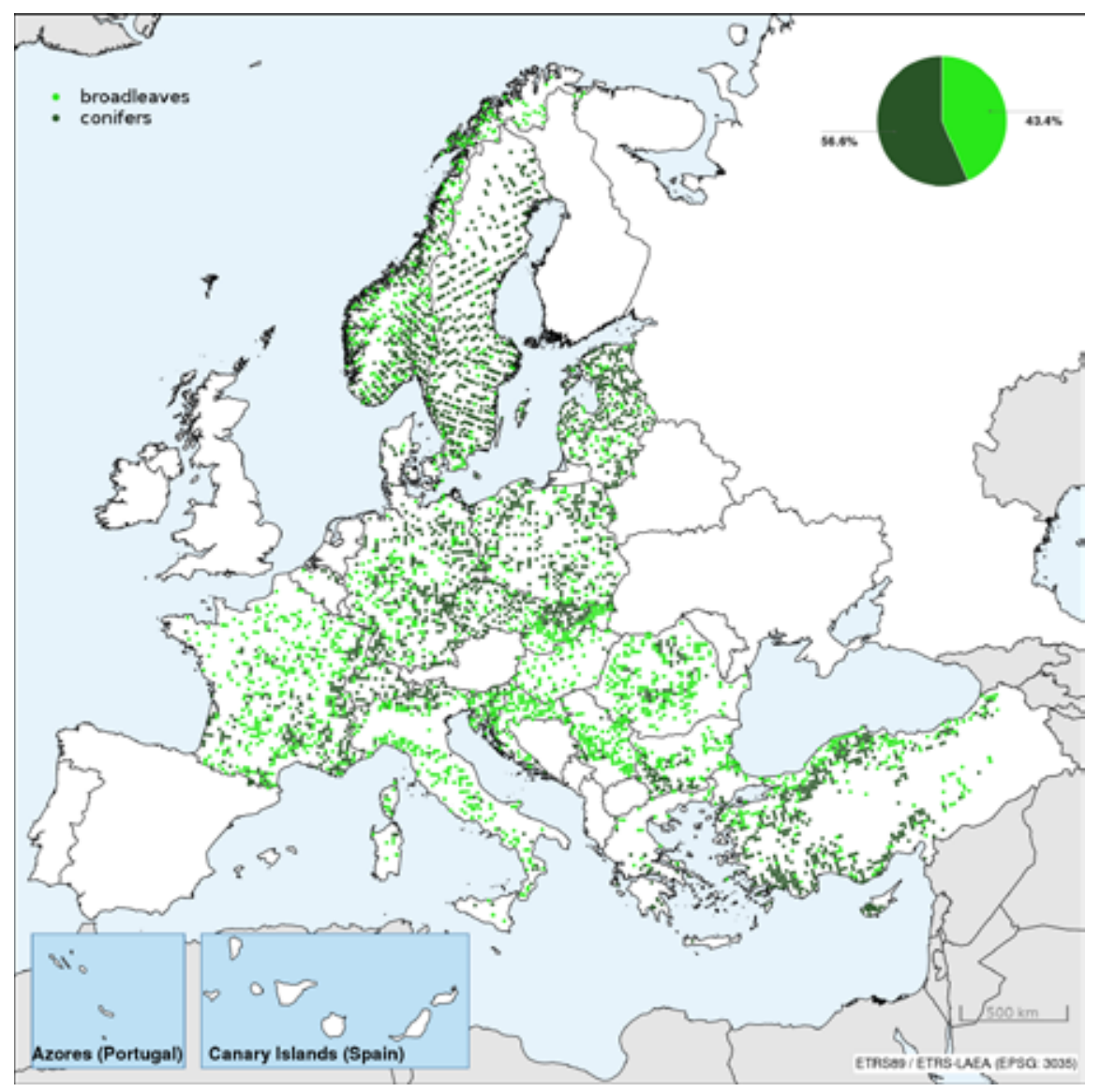

In order to monitor the health and vitality of forests in Turkey, efforts were initiated within the framework of International Cooperation Program for Monitoring and Evaluating the Impacts of Air Pollution on Forests (ICP), and level -1 and level-2 programs based on intensive monitoring have been commissioned. Monitoring continues in a total of 6,000 level-1 observation areas in 41 countries, including 850 in Turkey, and a total of 500 level-2 observation areas in 42 countries, including 52 in Turkey.

\subsubsection{Afforestation}

Starting in 2002 some 4 million ha have been subject to some form of forestation intervention. The current annual program of approximately 250,000 ha includes 50,000 ha of afforestation, 80,000 ha of erosion control, 10,000 ha of rehabilitation of alpine meadows and 105,000 ha of forest rehabilitation. There is increased emphasis on watershed-based activities and on trying to support the development of rural communities through the planting of suitable (revenue earning) tree species e.g. walnut, almond, olive and pistachio.

Included under afforestation is the establishment of industrial plantations, mainly of Brutia pine ( $P$. brutia) and Maritime pine ( $P$. pinaster and formerly $P$. maritima). The GDF has an action plan for these two species which foresees the establishment of 140,000 ha of Brutia pine and 20,000 ha of Maritime pine over the next twenty years. To date (at the end of the fourth year) a total of 19,338 ha of industrial plantains have been established. These two tree species are relatively high yielding and the aim is to achieve yields of 15 to $18 \mathrm{~m}^{3}$ per ha per year over the planned rotation lengths. Planting is on sites with either productivity class I or II (bonitet) and with a slope of less than 30 percent which 
TABLE 10 VOLUME OF TIMBER SOLD BY GDF ('000 M³)

\begin{tabular}{|c|c|c|c|c|c|c|}
\hline \multirow[t]{2}{*}{ Year } & \multicolumn{2}{|c|}{ Industrial Wood } & \multicolumn{2}{|c|}{ Fuel Wood } & \multirow[b]{2}{*}{ Total } & \multirow[b]{2}{*}{ Villagers } \\
\hline & Volume & Villagers & Volume & Villagers & & \\
\hline 2012 & 14,424 & 74 & 4,825 & 2,504 & 19,249 & 2,578 \\
\hline 2013 & 13,668 & 64 & 4,486 & 2,441 & 18,154 & 2,505 \\
\hline 2014 & 14,923 & 80 & 3,943 & 2,265 & 18,866 & 2,345 \\
\hline 2015 & 16,638 & 80 & 4,612 & 2,184 & 21,250 & 2,264 \\
\hline
\end{tabular}

Note: Units are '000 $\mathrm{m}^{3}$

Dozers were used for slopes up to 50 percent with excavators on slopes greater than this or where a large proportion of rocks. More recently contractors use excavators across all site types. During road planning local stakeholders are consulted regarding the most appropriate route. Typically, the road survey is undertaken in year one with formation in year two and completion in year three. Construction costs vary with the terrain and typically range from US $\$ 7,400$ to US $\$ 18,500$ per $\mathrm{km}(20,000$ to $50,000 T L$ per $\mathrm{km}$ ). While there is awareness of the environmental impact of road construction e.g. locating the road further up slope, there is no EIA requirement and no best practice environmental guidance. The general perception in the sector is that road standards are appropriate but there is a need to improve construction techniques.

\subsubsection{Wood Production and Sales}

The GDF is the dominant supplier of roundwood in Turkey and sells 18-21 million $\mathrm{m}^{3}$ annually. Of this approximately 6-7 million $\mathrm{m}^{3}$ is fuel-wood and 13-16 million $\mathrm{m}^{3}$ industrial wood comprising 7 million $\mathrm{m}^{3}$ wood used for fiber and chipboard sector, 5 million $\mathrm{m}^{3}$ sawlogs (mainly coniferous) and the balance is made up of other assortments e.g. poles, pit props etc. Some 36 percent of fuelwood and 0.5 percent of industrial wood is supplied to the villagers at a discounted price.

GDF sells its roundwood by auction, standing sale or allocation (under guaranteed supply contracts). Auctions are organized at the Forest District level with volumes based on the management plans. The frequency of auctions varies depending on the forest resources in the district. On average there are 350 auctions per month for the 245 Forest Districts. Auction commissions in each district oversee the sales process. A recent initiative is the provision of a supply allocation to those enterprises with an annual roundwood intake of $25,000 \mathrm{~m}^{3}$ or greater in the fiber and chipboard and paper sectors which collectively account for circa 30-35 percent of sales. Prices cannot be less than current market prices for the particular assortment / log mix. Standing sales are currently 20 percent of roundwood sales.

The majority (95 percent) of harvesting operations in GDF forests are undertaken by forest villagers and there is a legal obligation to offer this work to villages. The technology used is basic with manual felling / cross-cutting in the wood and extraction to roadside using tractors (MB Trac or similar). The harvesting price is set locally based on a combination of tree size, slope and distance according to a central approved methodology. The average harvesting cost for the GDF is circa US\$25.9 per $\mathrm{m}^{3}$ (70 TL per $\mathrm{m}^{3}$ ). This is considered high in comparison with many European countries and this stems from the technology and methods used. Haulage uses rigid lorries and self-propelled loaders. In the event that there is insufficient village labor capacity or if villagers refuse to undertake the harvesting then the work can be offered to contractors. This practice, while having a strong social objective, militates against the use of improved technology and greater efficiency. There is no well-developed contracting infrastructure and one will not develop until such time as current work practices, including methods of sale change.

The GDF operate a protocol with the Ministry of Education regarding training and all forest villages have received an eight-day training course on harvesting, safety and personal protection equipment (PPE). Attendees receive a certificate on completion of the course and this is seen as a transition stage to a qualified village workforce. 
The private sector produces circa 3.5 million $\mathrm{m}^{3}$ of roundwood, predominantly pulp wood for the wood panels sector.

\subsubsection{Wood Energy}

Wood is a major source of renewable energy but the increasingly widespread use of solar heating and water heating systems, natural gas and heat insulation in rural areas has led to a decrease in the production and consumption of fuelwood particularly since 2000. Under the Forest Law, forest villagers have a right to collect fuelwood for domestic purposes and to receive fuelwood at subsidized prices from GDF.

Annual average firewood consumption in Turkey is estimated as being of the order of 10-11.5 million $\mathrm{m}^{3}$. Firewood production is 6-7 million $\mathrm{m}^{3}$ (4.5-5 million $\mathrm{m}^{3}$ from state forests and 1.5-2.0 million $\mathrm{m}^{3}$ from private afforestation) in recent years. The shortfall of 4-4.5 million $\mathrm{m}^{3}$ comprises harvesting waste utilization, cutting trees from own gardens and other sources. Migration from the forest villages to cities, expansion of central home and water heating systems, increasing use of solar energy and natural gas and heat insulation has resulted in decreasing consumption and production of firewood, especially from 2000 onwards.

The use of and demand for wood charcoal has grown in recent years but is still small in comparison with firewood use. It is still widely produced by migrant charcoal producers using traditional earth mound kilns. The total annual income of charcoal producers in Turkey is calculated as 140 million US $\$$ and is based on a price of 0.70 US $\$ / \mathrm{kg}^{32}$ This is equivalent to 200,000 tons.

There is only limited use of forest residues for energy. The sector is largely undeveloped with a small number of briquette producers and limited use of wood chips for energy by industry. The GDF estimates the potential residue market as being of the order of 5 to 7 million tons annually. ${ }^{33}$
The GDF established a Bioenergy Commission which reported in 2008. Following on from this, it has initiated projects using forest residues for heating in administrative buildings. The GDF is also planning small scale electricity production ( $250 \mathrm{~kW}$ ) through wood gasification suitable for rural areas and villages.

Law 5346 on Utilization of Renewable Energy Resources for Generating Electricity provides a guaranteed feed-in tariff for electricity generated from renewable sources. To date this has had little impact on the use of woody biomass and there are no combined heat and power (CHP) plants. The strong raw material demand from the wood panels sector and its continuing expansion is limiting the material available for wood energy and acting as a deterrent to investment. The expectation is however that the legislation together with other initiatives e.g. Climate Change Strategy, will result in the wider use of woody biomass over time.

\subsubsection{Hunting and Game Management}

Up until 2003, hunting was managed according to the provisions of the Land Hunting Law enacted in 1937. To strengthen the legal framework for the protection, improvement and sustainable management of game and wildlife resources a new Hunting Law was introduced complying with relevant EU legislation and international conventions to which Turkey is a signatory. The new law authorizes the Ministry of Forestry and Water Affairs (MFWA) for the regulation, organization and control of hunting. The GDNCNP is responsible for the management of the game and wildlife resources. It has worked with hunting associations and NGOs to establish a country-wide warden network to facilitate inspection of hunters and to control illegal hunting. Wardens operate on a voluntary basis. The GDNCNP is also responsible for the designation and management of protected areas. It has seven game breeding stations - four for partridge and three for pheasant - the purpose of which is to support the existing game bird populations and also for hunting.

\footnotetext{
32. Kayhan Menemencioglu (2013) Traditional wood charcoal production labour in Turkish forestry (Cankırı sample) Journal of Food, Agriculture \& Environment Vol.11 (2): 1136-1142. 2013

33. National initiative and strategy development for strengthening utilization of wood energy in Turkey. Presentation by Ismail Belen to Workshop on Policy options for wood energy. 1-4 June 2010 Minsk, Belarus.
} 
The Central Hunting Commission established under the law comprises 21 members selected from MFWA, MFAL, NGOs, academia, private hunting ground owners and hunting organizations. It sets annual figures for bag limits, permitted hunting methods, hunting days, permitted and prohibited hunting grounds, species to be protected and not hunted and open seasons for species groups according to region.

Hunting is organized locally through local hunting associations which are affiliated to Regional Hunting Federations which in turn are represented nationally by the Hunting Confederation. The right to hunt follows the ownership of the land and hunting associations can purchase hunting rights to permitted hunting grounds either from private owners or through the GDNCNP for state lands.

\section{TABLE 11 GD NATURE CONSERVATION AND NATIONAL PARK REVENUE FROM HUNTING ('OOO US\$)}

\begin{tabular}{|r|r|r|r|}
\hline Year & Agencies & Private Hunters & Total \\
\hline 2012 & 4,161 & 1,480 & 5,641 \\
\hline 2013 & 4,369 & 1,554 & 5,923 \\
\hline 2014 & 4,586 & 1,632 & 6,217 \\
\hline
\end{tabular}

According to the Wildlife Management Department of the DG Nature Conservation and National Parks, there are two types of revenue from the hunting/ game in Turkey. The first is from hunting and / tourism agencies which are officially registered (get permission) each year during the hunting season and pay for hunter's groups especially foreign and the second one is private hunters who also apply individually for permission and pay in a similar way. In 2015 scope revenues of 25,828,287 TL or 9,556,466 USD were generated as the share allocated to DG Nature Conservation and National Parks from sales of hunting permits, training of hunters, hunting tourism, contributions from hunter offices and hunting charges.
Large game such as wild goat, Anatolian mouflon, red deer, roe deer, pheasant, wolf, brown bear and wild boar are allowed to be hunted in the light of game management plans within the scope of hunting tourism by the permission of the MFWA. Foreign hunters can either avail of the services of registered hunting companies or apply direct to GDNCNP for the required hunting permit. There is potential to increase hunting revenues through the development of quality hunting tourism.

The DGNCNP prepares game management plans for the main game species. Unlike game management in Europe, predator species are not interfered with. Based on a combination of returns from hunters and the observations and monitoring of DGNNP staff the recent trend is for the large game populations to increase. The range of these species is also increasing.

\subsubsection{Non-wood Forest Products and Ecosystem Services}

\section{a) Non-wood Forest Products (NWFPs)}

The international trade of selected NWFP commodity groups reached US\$ 12 billion in 2011 and trade has shown steady growth over the previous years. ${ }^{34}$ Increasing demand and increasing range of products has typified the sector over the past decade and the overall outlook for growth is considered good, despite the recent economic recession. The $E U$ has a strategic role in the international NWFP market accounting for the 44.8 percent of the total export value of commodities based on raw or processed NWFP.

Turkey is considered rich in terms of non-wood forest products (NWFPs). Due to the different climatic and geographic conditions, it is home to a wide variety of tree, shrub and herbaceous plant species. Of the estimated 12,500 plant species in Europe, Turkey has circa 11,707 plant species of which 3,649 are endemic ${ }^{35}$, of which 3,900. About 138 different NWFPs are obtained from Turkey's

\footnotetext{
34. Wong JLG \& Prokofieva I (Eds) (2014) Report presenting synthesis of regional sectoral reviews to describe the "State of the European NWFP". StarTree deliverable D1.3. 96 pp, references and 3 Annexes

35. Turkey Biological Diversity Monitoring and Evaluation Report 2012
} 
forests, but so far there has been no systematic management planning for these resources, mainly because the necessary institutional capacity still needs to be built. The majority of the NWFPs are found in forests, principally along the coast line with canopy cover less than 11 percent (degraded forest).

Turkey is one of the top three producers worldwide for laurel leaves, thyme, sage and pine nuts and is ranked $21^{\text {st }}$ in the world in terms of exports of NWFPs. The major exports in 2010 were pine nuts (US\$ 68.3 million), thyme (US\$ 28.1 million), laurel leaves (US\$25.6 million), plants for weaving (US\$ 23.3 million) and mushrooms (US\$ 11.8 million). ${ }^{36}$ The principal importer of NWFPs in 2010 was the USA, followed by Germany, Japan, France, and Hong Kong.

Only 20 percent of NWFPs receive any form of processing or added value in Turkey. The majority are exported unprocessed. There are no imports of NWFPs and all raw materials are supplied domestically using local labor. Despite increases in exports (up 21 percent in 2011 compared with 2010) and domestic processing of NWFPs, Turkey's rich floral diversity is still largely untapped. About 1000 species of plants are consumed in households for remedial purposes.

Herbs and spices classified as NWFPs are widely available, particularly in the cosmetics, medicine, food, dye and chemical industries. Plants are the natural and biological raw materials for many sectors starting with the pharmaceutical industry and it is estimated that up to 500 plants are used for medical purposes in Turkey.

NWFPs have traditionally been collected by forest villagers at low prices (Tariff price). Permission and the amount to be collected is decided by the GDF, and endangered plant species are protected to sustain the biological and genetic diversity. Despite efforts by the GDF in the early 2000s, including conducting workshops and organizing panels to improve sustainable management of NWFPs and increasing their contribution to the rural economy, there is insufficient added value and many NWFPs are exported in an unprocessed state. However, there is an increasing volume processed in Turkey in recent years. The amount of non-wood forest products reached 429,000 tons as of end-2016, up from 31,000 tons in 2002. The GDF organized two workshops with the participation of specialists and private sector representatives: Medical and Aromatic Plants Center Strategy and Target Setting Workshop organized in Afyonkarahisar on 28 February-01 March 2015, and Second Medical and Aromatic Plants Workshop organized on 12-13 March 2016, the concluding reports for of which have been published as a bulletin. Forest managers believe that the area of NWFPs, while currently of only moderate importance, will become increasingly important into the future and on a par with biological diversity. ${ }^{37}$ A NWFP and services department was established in the GDF headquarters in 2011 and under the current Strategic Plan there are targets for an inventory of NWFPs by 2017 and measures for their sustainable utilization.

The 2013-2017 Strategic Plan requires the new inventory to ascertain the full potential of NWFPs as a priority area, including the identification of their current state in terms of natural habitats and sustainability. The focus is on higher economic value products and preparing plans for their sustainable use. The integration of biodiversity and inventory data into forest management plans will support planning for the sustainable development of NWFPs. Since 2012 efforts have been made to identify and assess the status of non-wood forest products and their potential. Inventory and planning studies have been undertaken on an area of 1.4 million ha, covering a total of 210 different species. The 2017-2021 Strategic Plan envisages studies to be conducted on an area of 1,9 million ha by 2021. In addition, inventory and planning work is envisaged to involve specialization training as well as appropriate employment policies. The low level of active management of NWFPs is a common feature across Europe as shown in Figure 14.

36. Turkish Export Assembly. http://www.tim.org.tr/en/news-recent-news-a-curative-source-of-income.html

37. Kuvon et al (2011). Forest manager perceptions of the foremost forestry issues and functions in Turkey. Polish J. Environ. Stud. Vol 20, No. 2 (2011), 393-403. 
FIGURE 14 ACTIVE MANAGEMENT OF NWFPS IN 13 EUROPEAN REGIONS

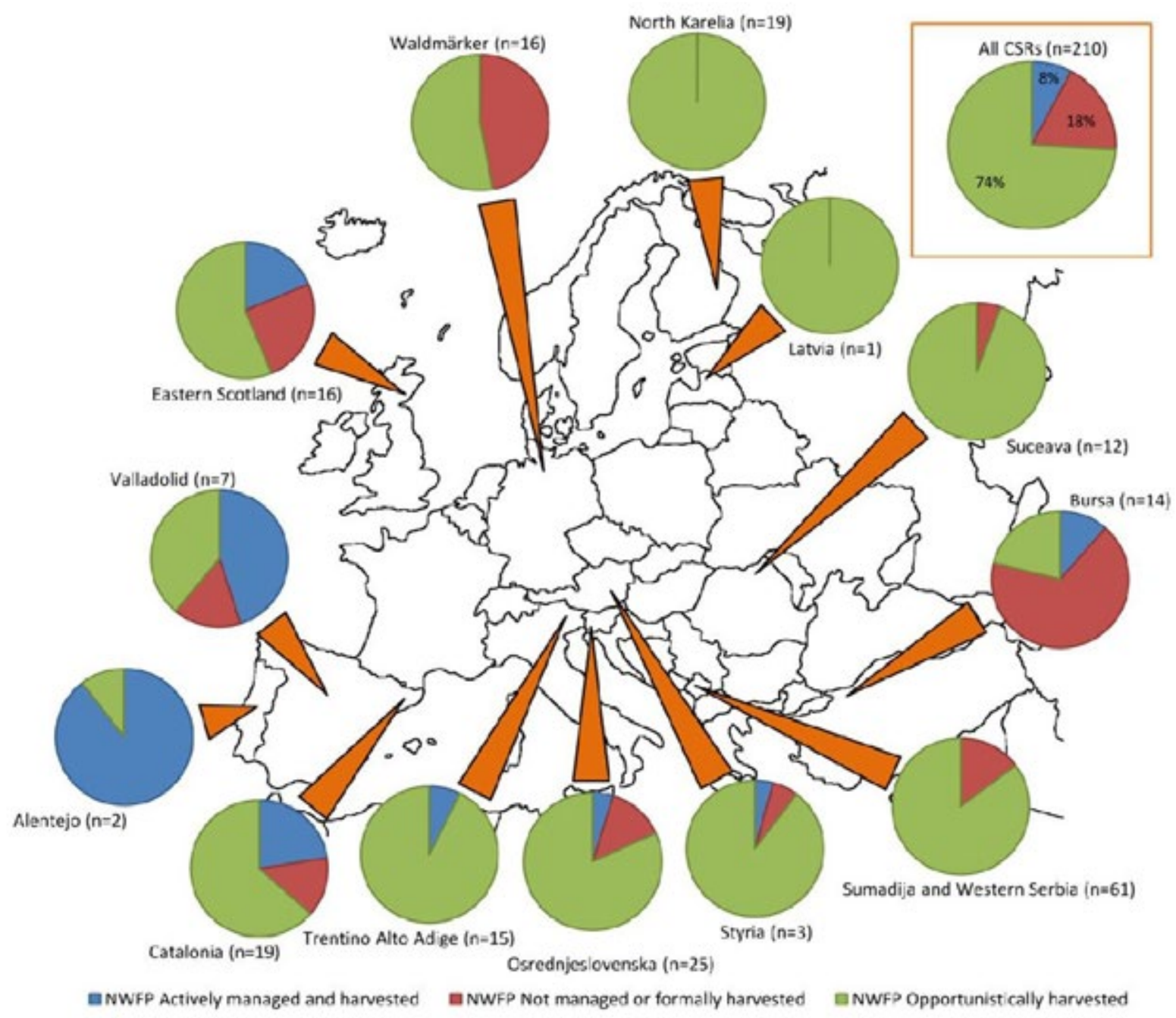


The recent World Bank assessment of nonwood forest ecosystem services estimated the value of NWFPs for Turkey as US\$2.3 per hectare per year, compared with an average for Europe of US\$ 20.7 indicating a significant potential for growth in the future. ${ }^{38}$ This is reinforced by the findings from the EU StarTree project which show that Turkey has not as yet fully exploited the potential for cultivated forms of NWFPs or undertaken management of these resources at an intensity as practiced in some countries (Figure 14). ${ }^{39}$

Non-wood forest products are a major opportunity and potential source of income and employment for those who live in rural areas. The diversity of products, the potential for in-country processing and added value represent a significant opportunity for rural communities. The emphasis should be on the development on processing products with high added value as opposed to simply harvesting and export of unprocessed NWFPs.

\section{b) Ecosystem Services}

There is growing recognition that forests can provide many benefits, identified as ecosystem services. Some of these, such as recreation, relaxation, or shelter are well appreciated by the general public while others are less understood, or simply taken for granted. The Millennium Ecosystem Assessment of $2005^{40}$ defined ecosystem services as provisioning (food, water, wood, genetic resources), regulating (climate, floods, disease, water quality), cultural (recreation, spiritual benefits) and supporting (soil formation, primary production).

Under Law No 3234 on the Organization and Tasks of the General Directorate of Forestry, it has responsibility for the provision of recreation areas in forests for public use. An Urban Forests Project was launched in 2003 by GDF and is ongoing. A total of 145 urban forests have been developed encompassing 10,550 ha adjacent to or in the vicinity of cities and towns as of the end of 2016.
Their purpose is to provide for the health, sport, aesthetic, cultural and social needs of the public while increasing awareness of flora and fauna.

At the end of 2016, a total of 1,304 forest areas amounting to 16,266 ha have been developed as inforest recreational sites in order to meet the daily recreational and picnic requirements of the public. In recent years there has been a rapid development in nature tours of varying duration organized by both private sector companies and NGOs for recreational and training / educational purposes in forest areas.

\section{c) Economic Value of Ecosystem Services}

The World Bank estimates of the total nonwood forest wealth are 2.7 times greater, on average, than those derived previously. The previous estimates are about 39 percent of the revised estimates, on average, globally ( $\$ 26$ per hectare per year versus $\$ 67$ per hectare per year, in 2013 U.S. dollars). Adding NWFPs and considering the revised measure of accessible forest area increases the revised estimate to $\$ 84$ per hectare per year. The estimate for Turkey is $\$ 133$ per hectare per year - water $\$ 98.4$, NWFPs $\$ 2.4$, habitat $\$ 1.3$ and recreation $\$ 31.2 .{ }^{41}$

A pilot study ${ }^{42}$ in the Bolu region on the total economic value (TEV) of forestry was completed in 2015. The direct use, option, indirect use, and nonuse values of forest products and services were estimated through the use of various valuation methods. The estimated total net economic value (TEV) was US $\$ 666.3$ million in 2013 (Table 12). The largest portion of the TEV were the indirect use values arising from ecosystem services, including watershed protection, carbon sequestration and soil erosion control, which amounted to US\$341.4 million or 50.0 percent of the TEV. In traditional national accounting, these values are largely unaccounted for or partially included in the valueadded of other sectors, such as cost reduction of water supply.

\footnotetext{
38. Siikamäki, J., Santiago-Ávila, F. and Vail, P. (2015) Global Assessment of Nonwood Forest Ecosystem Services. PROFOR Working Paper.

39. Wong JLG \& Prokofieva I (Eds) (2014) Report presenting synthesis of regional sectoral reviews to describe the "State of the European NWFP". StarTree deliverable D1.3. 96 pp, references and 3 Annexes

40. Millennium Ecosystem Assessment, 2005. Ecosystems and Human Well-being: Synthesis. Island Press, Washington, DC.

41. Siikamäki, J., Santiago-Ávila, F. and Vail, P. (2015) Global Assessment of Nonwood Forest Ecosystem Services. PROFOR Working Paper.

42. World Bank (2015) Valuing Forest Products and Services in Turkey: A Pilot Study of Bolu Forest Area. Washington: DC.
} 
TABLE 12 TOTAL ECONOMIC VALUE OF FOREST GOODS AND SERVICES IN BOLU 2013

\begin{tabular}{|c|c|c|c|c|c|}
\hline Value Type & Products and Services & $\begin{array}{r}\text { TEV } \\
(\text { million } \$)\end{array}$ & $\begin{array}{r}\text { TEV } \\
(\$ / \text { ha/year })\end{array}$ & Valuation Method & $\%$ \\
\hline \multirow{8}{*}{$\begin{array}{l}\text { DIRECT USE } \\
\text { VALUE }\end{array}$} & Timber & 75.0 & 145.9 & Market price & 11.0 \\
\hline & Firewood & 10.4 & 20.2 & Market price & 1.5 \\
\hline & NTFP-Plants & 0.5 & 1.0 & Market price & 0.1 \\
\hline & Honey & 5.3 & 10.4 & Market price & 0.8 \\
\hline & Recreation & 12.0 & 23.4 & Unit value number & 1.8 \\
\hline & Fodder for grazing & 212.8 & 413.9 & Market price & 31.1 \\
\hline & Hunting & 0.5 & 0.9 & $\begin{array}{l}\text { Cost-based } \\
\text { valuation }\end{array}$ & 0.1 \\
\hline & Total direct use value & 316.6 & 615.6 & & 46.3 \\
\hline \multirow[t]{2}{*}{ OPTION VALUE } & Pharmaceutical & 6.1 & 11.8 & Unit value transfer & 0.9 \\
\hline & Total option value & 6.1 & 11.8 & & 0.9 \\
\hline \multirow[t]{4}{*}{$\begin{array}{l}\text { INDIRECT USE } \\
\text { VALUE }\end{array}$} & Watershed protection (water supply) & 125.4 & 243.9 & $\begin{array}{l}\text { Adjusted value } \\
\text { transfer }\end{array}$ & 18.4 \\
\hline & Carbon sequestration & 112.2 & 218.2 & $\begin{array}{l}\text { Standard value } \\
\text { transfer }\end{array}$ & 16.4 \\
\hline & Soil erosion control & 103.7 & 201.7 & Unit value transfer & 15.2 \\
\hline & Total indirect use value & 341.4 & 663.8 & & 50.0 \\
\hline \multirow[t]{3}{*}{ NONUSE VALUE } & Biodiversity & 19.2 & 37.4 & Unit value transfer & 2.8 \\
\hline & Total non-use value & 19.2 & 37.4 & & 2.8 \\
\hline & Total value & 683.4 & & & 100.0 \\
\hline \multirow[t]{3}{*}{$\begin{array}{l}\text { GENERAL COSTS } \\
\text { AND NEGATIVE } \\
\text { EXTERNALITIES }\end{array}$} & $\begin{array}{l}\text { Expenditure on soil conservation, } \\
\text { afforestation, range management } \\
\text { and rehabilitation of degraded } \\
\text { forests }\end{array}$ & 3.1 & & Actual expenses & 18.2 \\
\hline & Soil erosion for degraded forests & 14.0 & & Value transfer & 81.8 \\
\hline & Total costs & 17.1 & & & 100.0 \\
\hline
\end{tabular}

The pilot study showed that the economic value of various forest products and services, which is normally unaccounted for or accounted implicitly in non-forest sectors, is seven times the value currently accounted as the forest sector's contribution. In terms of GDP, the known and accounted value (US\$ 86.4 million) of forest products was about 0.50 percent of the regional GDP in 2013. The pilot study showed that the TEV of forest products and services was US\$ 666.3 million equivalent to 3.9 percent of regional GDP. The TEV is a truer reflection of the value and contribution of forests to the regional economy, and could help guide development programs and policies towards forest protection and a more sustainable use of forest resources; for instance, the justification for and prioritization of public expenditure in the forest sector to provide public goods and externalities to the national and regional economy.

The value attributed to fodder, accounting for 32 percent of TEV, appears relatively high. However, it is not without precedent and TEV analysis in Tunisia ${ }^{43}$ and Algeria ${ }^{44}$ provided values of 55 percent and 33 percent respectively. Notwithstanding this, the estimated value of US\$ 414 per ha is considered high. In contrast, the value attributed to NTFPs (plants) at 0.1 percent of TEV is extremely low in

43. TEEBcase (2013) Economic valuation of forest goods and services, Tunisia, by Hamed Daly-Hassen, available at: TEEBweb.org 44. Valuation of FES, Implementation of the Valuation: Serbian experience. Stamatović Saša 2014. Downloadable from http://www. foresteurope.org/sites/default/files/3_3_Sasa_Stamatovic.pdf 
comparison with other studies ${ }^{20,21}$ and especially in view of the richness of plant flora in Turkey. Similarly, the contribution from timber at 11 percent of TEV is at variance with other studies. ${ }^{45}$ Thus while the pilot study does provide some insight into the TEV of Turkey's forests, the results will need to be validated before they could be considered sufficiently robust to be applied nationally.

\subsection{Socio-economic and Environmental Functions and Services}

\subsubsection{State Forestry Sector and Forest Villages}

Turkey's rural inhabitants can be classified into two groups, namely forest villagers and the other villages. Forest villages are also divided into villages located inside forests or those near/adjoining forests. They are also classified on the basis of whether or not production is performed in forests within village boundaries, under Articles 31 and 32 of the Forest Law No. 6831. This classification also plays a determining role in terms of the products generated from forests and subsidies provided. Thirty-five years ago there were approximately 18 million forest villagers and according to data for 2014, 7,096,483 people live in 22,343 forest villages, constituting approximately 9.6 percent of the national population and 40 percent of the rural population. Forest villages are included in the group claiming the least share of national income per capita. Agricultural land in the forest villages is frequently inadequate and is highly fragmented, rugged and low in fertility. ${ }^{46}$

The population in forest villages is declining due to out-migration to urban areas in search of employment and better opportunities. According to a recent socio-economic survey of forest villagers (described below) approximately 37 percent of village members leave. ${ }^{47}$ This out- migration is moderately skewed towards males leaving (60:40), but in poorer villages the gender ratio is the same (52 percent male). The average age in poorer villages tends to be about 4 years younger than the survey population, while richer villages are 2 years older.

The migration from villages to urban areas is expected to continue. Low levels of welfare and poverty due to a lack of income sources, infrastructure and social services which have been some of the main reasons for out-migration in the past. ${ }^{48}$ The rate of unemployment in forest villages, calculated from the survey described below, is estimated to be about 11 percent $^{49}$ The income generated by forests to the livelihoods of forest villagers is at an inadequate level. ${ }^{50}$ This observation was confirmed from survey findings where the share of income from forest-related activities is only 14 percent (including forest collection, employment, and payment for forest services). This is resulting in lower expectations by forest villagers about the potential for forest resource income, and is one of the main reasons driving the migration trends from forest villages. ${ }^{50}$

A growing source of income for forest villagers is from non-forest related jobs and a heavier reliance on agriculture. The average agricultural holding of 2.4 ha is mostly used for subsistence farming so it affords a limited opportunity for additional income. Forestry work is seasonal and lasts for approximately five months, mostly in winter and is done under very harsh working conditions. The changing demographic profile is limiting the ability of forest villages to undertake the hard physical forest work (e.g. harvesting, is reducing over time). To meet their needs, households collect forest products for subsistence as well as for sale. From the survey, it was found that 61 percent of households in forest villages collect forest products and 16 percent who sell these products. Villagers most often collect firewood for subsistence and mushrooms, herbs, and nuts. Both men and

\footnotetext{
45. Bogdan, P. et al (2015) Forest Ecosystem Services Valuation under Different Management Scenarios: A Case Study of Maramures Mountains. In press

46. Forestry Directorate General Strategic Plan.

47. World Bank, 2016. Socio-economic Analysis of the Forest Villagers in Turkey. Funded by the Program for Forests (PROFOR).

48. Forestry Directorate General Strategic Plan 2013-2017.

49. Calculated as: Prime Age Unemployed / Prime Age Labour Force

50. Forestry Directorate General Strategic Plan 2013-2017.
} 


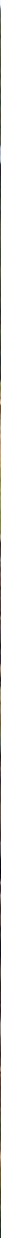

women are engaged in forest product collection, with approximately a 40 percent of the households using only men for collection. ${ }^{51}$

\subsubsection{Historical Background and Trends of Support to Forest Villages}

Responding to the fundamental changes in forestry approaches, the forestry sector has launched assistance programs to the forest villages to sustain forest resources and forestvillage communities as well.

Several initiatives and measures for the improvement in rural living conditions have broadly been implemented under the provisions of the Forest Law 6831 since the late 1950s. This Law provides the legal definition of forest and introduced the first set of forest policies and strategies.

Two articles (169 and 170) in the Constitution are directly related to the overall management and development of Turkey's forest resource. Article
169 focuses on the protection of state forests and Article 170 mandates the necessity of effective cooperation between the state and the inhabitants of forest villages through appropriate measures to be introduced by law for the purpose of improving their living conditions. The approach is based on the understanding that if the livelihood of the villagers can be supported and more income opportunities provided, then relations between the sector and villagers would allow for more efficient protection of forests and better living standards of forest dependent communities.

The General Directorate of Forest-Village Relations (GDFVR) was established under the Ministry of Forestry (MOF) in 1970 with the mandate to contribute to the social and economic development in forest areas. Accordingly, over time, assistance for village development initiatives and measures has increased in quantity and diversity. The GDFVR developed its activities through alternative employment opportunities and income generating facilities for forest villagers and cooperatives.

51. In deriving this percentage, only forest products collected by more than 10 households was considered. All households reported collecting over 70 different products (forest and agricultural) - but only 16 of which can be considered as forest products. 
In 1974, the General Directorate established the "Forest Village Development Fund" (FVDF) in accordance with the related articles of the Forest Law. The Law Nr. 1744 regulated the implementation structures of the Fund. It was financed by various sources including a certain portion of forest product sales, the profit of timber processing facilities and the general budget.

In addition to the FVDF, the state through the GDF has created subsidies / support for the forest villages in other ways such as employment rights in forest operations, sales of construction timber and fuel wood at highly discounted prices for their own needs, provision of forest planting materials such as seed, etc.

The aim of these subsidies and support can be summarized as:

a. Promoting the sustainability of rural community development and enhancing rural well-being;

b. Improving forest-people relations through increased participation and involvement in forest management practices; and

c. Reducing people's dependency on forest resources by the introduction of alternative income generating activities.

In 2011, the General Directorate of Forest-Village Relations (GDFVR) was closed. Its role and responsibilities were transferred to the GDF as a department. In this scope, since 2012, GDFVR revenues are being transferred completely to the Special Budget of General Directorate of Forestry. The aim of the Forest and Village Relations Department (ORKOY) is to contribute to the protection, development and attainment of the production targets of forests through supporting socio-economic development of forest villagers.

\subsubsection{Current Forestry Sector Support and Future Needs}

Forest villages are given preferential treatment under the Forest Law. Villagers under Article 40 have a right to employment in harvesting, thinning, afforestation, maintenance and transportation activities undertaken by the GDF. The GDF, through ORKOY, provides employment opportunities through various channels - including loans to individuals and cooperatives and this support has been increasing over time (Table 13).

ORKOY operates a grant/soft-loan program for individuals and cooperatives. The social credit support aims to improve the life quality of forest villagers and conserve forest resources through reduction of wood use as fuel and preventing the misuse of wood. Examples of social credit projects include: (a) roof covering materials, (b) central heating systems for households and energy efficient stoves with ovens, (c) solar water heating systems and (d) exterior thermal insulation. Economic-purpose credits are used for revenue generating and business projects and examples include: (a) animal husbandry support, (b) beekeeping, mushroom cultivation, medicinal and aromatic plant production support, (c) micro credit programs for housewives and (d) greenhouse, viniculture and fisheries.

Forest cooperatives play several roles, but an important one is to create employment opportunities for its members in forest villages (Table 13). Almost 60 percent of the total wood production of Turkey is carried out through cooperatives every year. Forest villagers generate production labor revenues of approximately US\$ 350 million annually - and some of this is retained within the villages through wages and income. In the past, this income was very important to 
TABLE 13 SUPPORT TO FOREST VILLAGES (FTE = FULLTIME EQUIVALENT)

\begin{tabular}{|c|c|c|c|c|c|}
\hline \multirow[b]{2}{*}{ Indicator } & \multirow[b]{2}{*}{ Unit } & \multirow[b]{2}{*}{$\begin{array}{r}\text { Average } \\
2011-2014\end{array}$} & \multicolumn{3}{|c|}{ Planned } \\
\hline & & & 2015 & 2016 & 2017 \\
\hline Employment created through loans to individuals & FTE & $2,098.0$ & $4,892.0$ & $6,158.0$ & $7,570.0$ \\
\hline Employment created through loans to cooperatives & FTE & $24,285.0$ & $24,695.0$ & $24,875.0$ & $26,060.0$ \\
\hline $\begin{array}{l}\text { Ratio of people to whom loan support is to be } \\
\text { extended to the total forest village population }\end{array}$ & $\%$ & 30.9 & 35.1 & 36.7 & 38.4 \\
\hline Wood savings provided through social loans & $\begin{array}{l}\text { Ooo } \\
\text { Stere }\end{array}$ & 658.0 & 902.0 & $1,002.0$ & $1,102.0$ \\
\hline
\end{tabular}

Source: GDF

Note: Not possible to give data for individual years due to changes in how information collected / collated (Mevlut)

\section{FIGURE 15 RANDOMIZED SAMPLE OF FOREST VILLAGES SURVEYED}

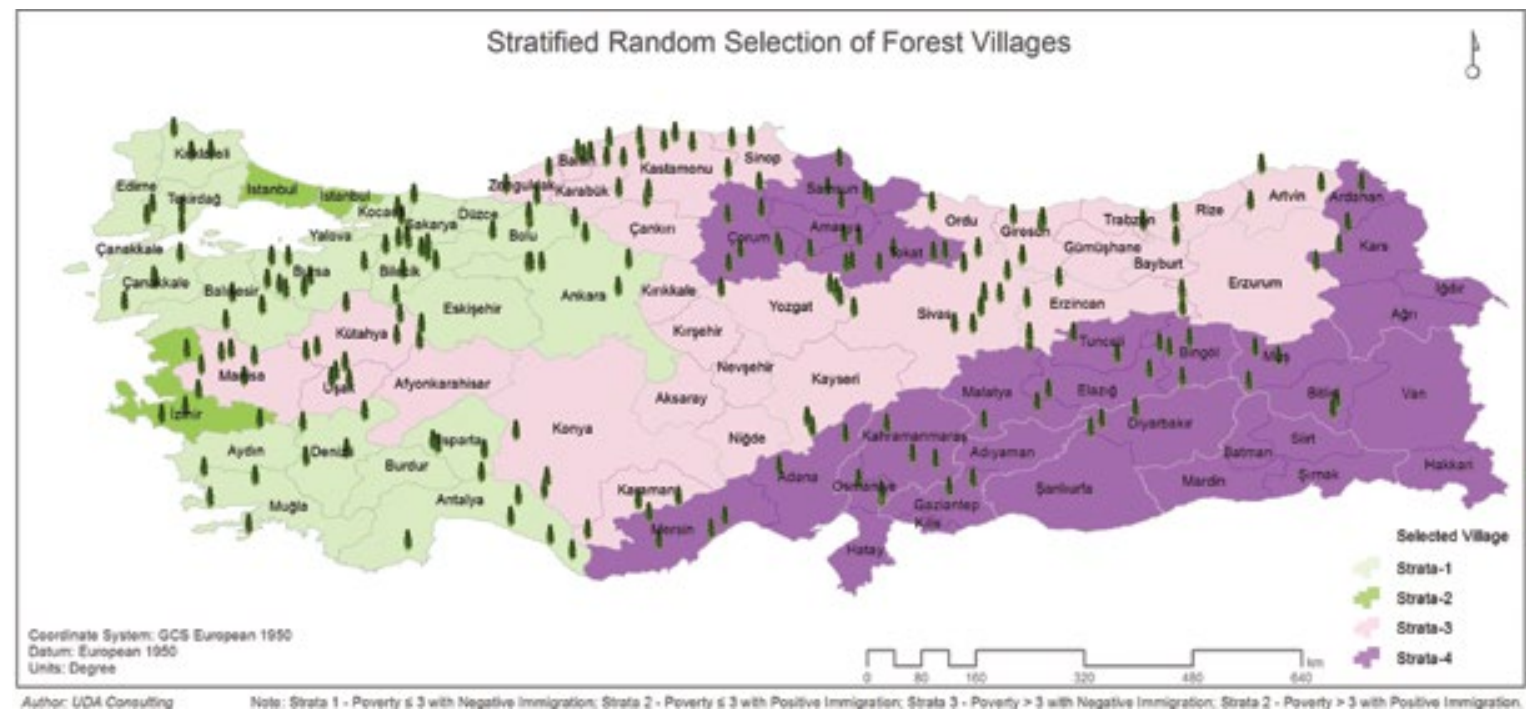

Source: World Bank (2016) Socio-economic Survey of Forest Villagers

support and maintain their living conditions in the forest. However, with declining village population and more limited forest income opportunities - the sustainability of this previous forest villager model appears to be in question.

\subsubsection{Socio-economic Survey of Forest Villagers}

To understand the current economic and social situation of forest villages - a socio-economic survey of forest villagers was recently undertaken (between February to August 2016) to support this forest policy note.52 Two thousand randomly- selected households in 203 representative forest villages were surveyed across Turkey. The sample was stratified into four regions according to poverty and net migration rates as well as by forest cover (Figure 15).

The survey's aim was to better understand the relationship between out-migration from forest villages, economic opportunities in forest communities, and the dependencies of household members on forest and forest resources. Villages from the survey are henceforth referred to in terms of their strata - that is high/low out-migration and high/low poverty (Table 14). ${ }^{53}$

52. World Bank, 2016. Socio-economic Analysis of the Forest Villagers in Turkey. Funded by the Program for Forests (PROFOR).

53. Only 6 villages ( 60 households) were surveyed as part of Strata 2 (low out-migration/high poverty). The reason is that there are very few areas characterized by low migration and high poverty in Turkey - hence the lower number in the sample. 
TABLE 14 SURVEY SAMPLE

\begin{tabular}{|c|c|c|c|}
\hline \multirow{4}{*}{ 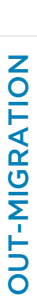 } & \multicolumn{3}{|c|}{ POVERTY } \\
\hline & & LOW & $\mathrm{HIGH}$ \\
\hline & 3 & $\begin{array}{l}\text { Low-Low } \\
\text { Strata } 1 \\
62 \text { villages }\end{array}$ & $\begin{array}{c}\text { Low-High } \\
\text { Strata } 2 \\
6 \text { villages }\end{array}$ \\
\hline & $\frac{\frac{I}{U}}{I}$ & $\begin{array}{l}\text { High-Low } \\
\text { Strata } 3 \\
77 \text { villages }\end{array}$ & $\begin{array}{l}\text { High-High } \\
\text { Strata } 4 \\
57 \text { villages }\end{array}$ \\
\hline
\end{tabular}

\section{a) Demographics of Forest Villages}

Table 15 summarizes some key household demographics by stratum. Low poverty and low migration regions have a higher male share as a household head (90 percent) than high migration areas (84 percent). Households in high migration and high poverty regions, on average, have a larger household size (4.1), and more prime working age members (2.7), compared with households in other strata. High migration villages tend to have younger populations and high poverty villages have the youngest average age (39 years as opposed to 42 years).

On average, about 50 percent of working age adults participated in the labor force, the majority of whom are men. The village level employment rate is 89 percent, yet many still claim to be 'underemployed' or not working to their full capacity. About 60 percent of those not in the labor force are housewives, 20 percent are retired and 19 percent are students. The survey shows that about 9 percent of adults reported to have never been to school, 94 percent graduated from primary school, 33 percent from middle school, 17 percent from high school and less than 4 percent from tertiary or higher schooling.

\section{b) Income Sources}

The income source analysis provided below summarizes the mean and median income received by those who participated in the activity (Table 16). It shows the relative productivity among the activities. Also indicated is the percentage of households who received income from that specific source. Both the mean and median are useful when comparing income across activities (productivity) and in different parts of the country. But when the mean is highly skewed by several large values (which is the case here), the median is a more appropriate measure of the value most commonly reported by forest villagers. It is also important to note that villagers typically receive income from more than one source - but not all of the ones listed below as this list is comprehensive. Therefore, one should not simply add up all the mean values to arrive at total income. Total income is listed as a separate row at the bottom of the table.

Forest-related income covers both income from forest product collection and forest wage income (items 1 and 2). Gross forest income (1a) consists of sales of forest product collection and subsistence value (the imputed income from household consumption of collected forest products). Net forest income (1b) is estimated by subtracting gross income from the cost associated with collecting forest products both for sale and own consumption (or subsistence value). The ranking of the importance of income sources is carried out both by the rate of participation and income level.

TABLE 15 HOUSEHOLD DEMOGRAPHIC STATUS BY STRATUM

\begin{tabular}{|l|r|r|r|r|r|}
\hline & $\begin{array}{r}\text { All } \\
\text { villages }\end{array}$ & $\begin{array}{r}\text { Low Migration - } \\
\text { Low Poverty }\end{array}$ & $\begin{array}{r}\text { Low Migration - } \\
\text { High Poverty }\end{array}$ & $\begin{array}{r}\text { High Migration } \\
\text { - Low Poverty }\end{array}$ & $\begin{array}{r}\text { High Migration } \\
- \text { High Poverty }\end{array}$ \\
\hline Male head (percent) & 95.0 & 97.0 & 93.0 & 94.0 & 93.0 \\
\hline Household size (number) & 4.1 & 3.8 & 3.3 & 4.1 & 5.1 \\
\hline Number of age <16 (percent) & 50.0 & 40.0 & 20.0 & 50.0 & 60.0 \\
\hline Number of age >65 (percent) & 50.0 & 50.0 & 70.0 & 50.0 & 2.0 \\
\hline Number age 16-65 (number) & 2.3 & 2.2 & 1.7 & 725.0 & 545.0 \\
\hline Number of households & $1,828.0$ & 431.0 & 60.0 & 2.0 \\
\hline
\end{tabular}




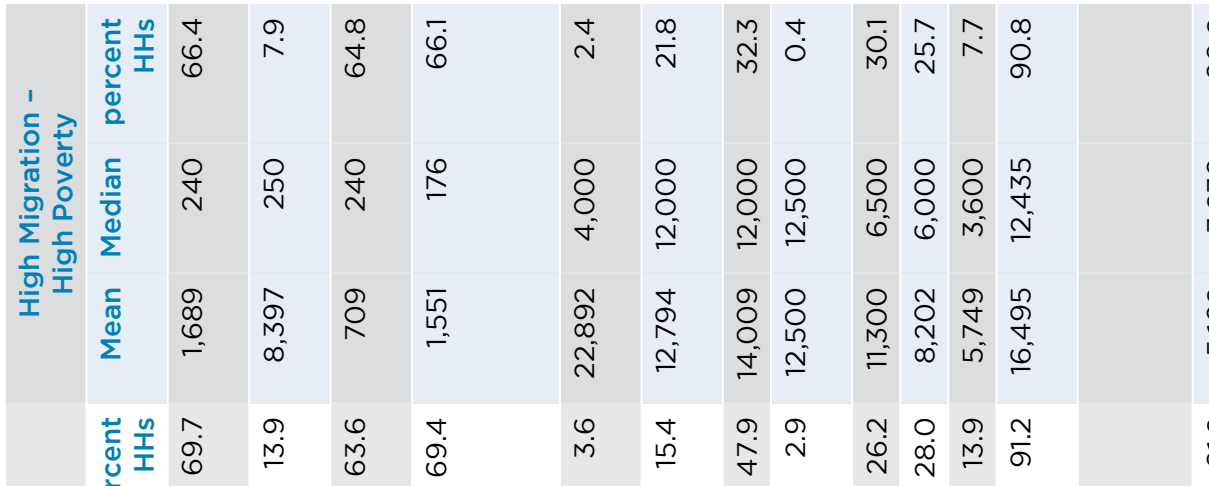

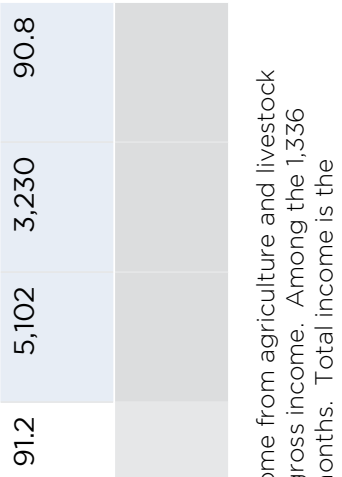

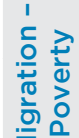

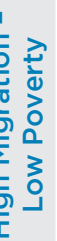

$\frac{\text { if }}{2}$

\section{든}

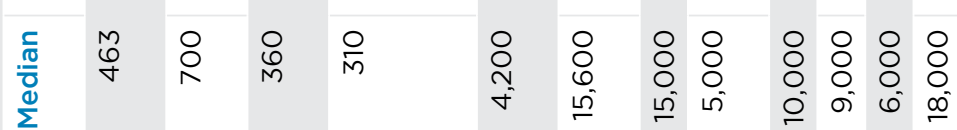

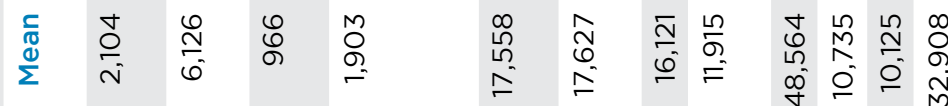

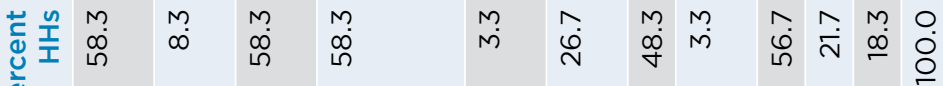

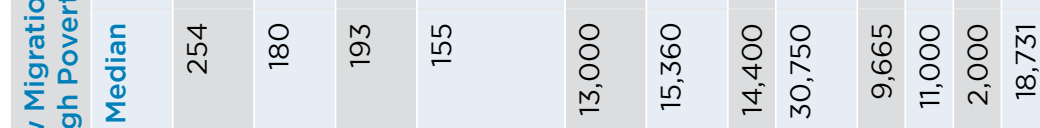

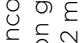

$\frac{10}{3}$

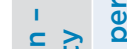

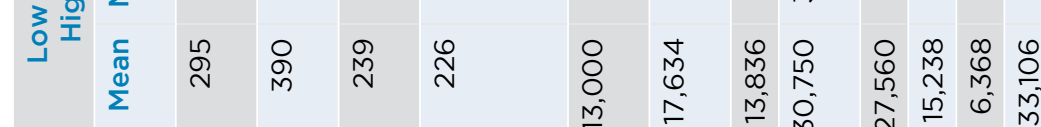

M $\cong$ m

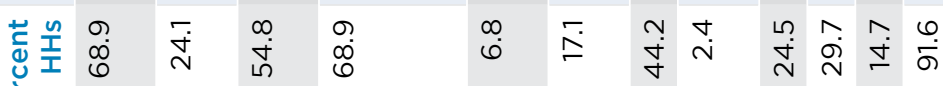

点

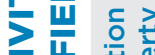

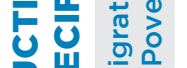

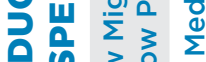

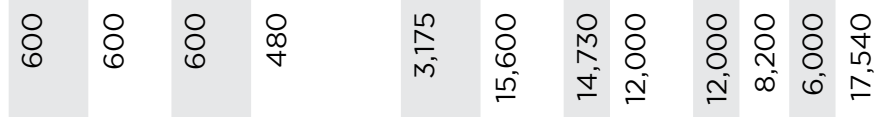

$\stackrel{\text { N }}{N}$

웅

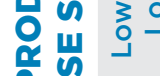

荝

$\rightarrow$ c

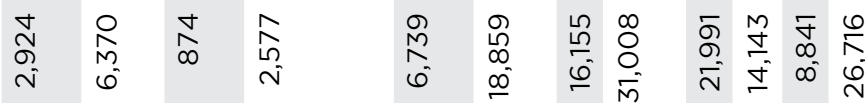

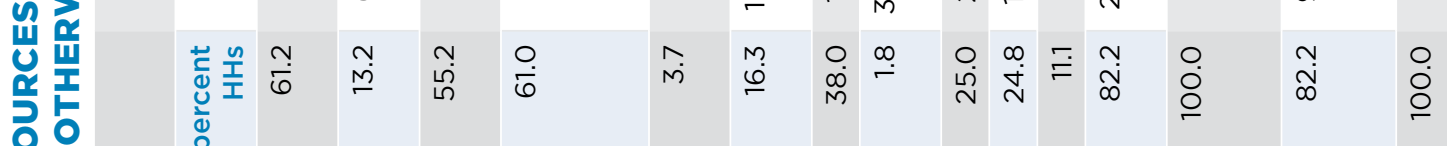

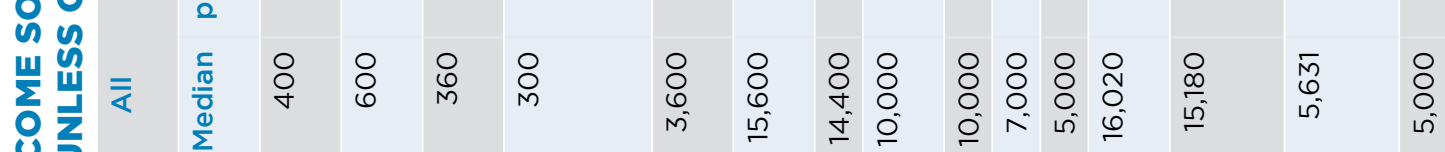

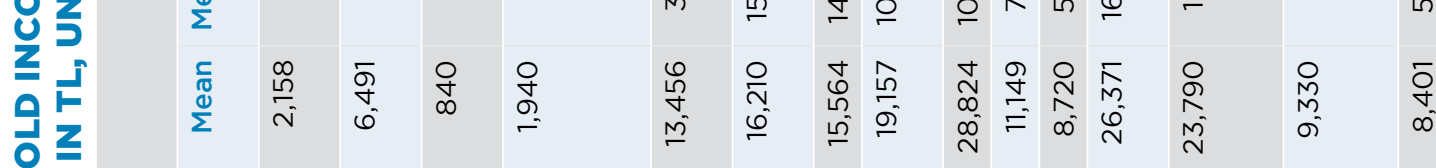

எே

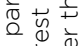

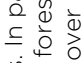

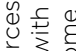

is

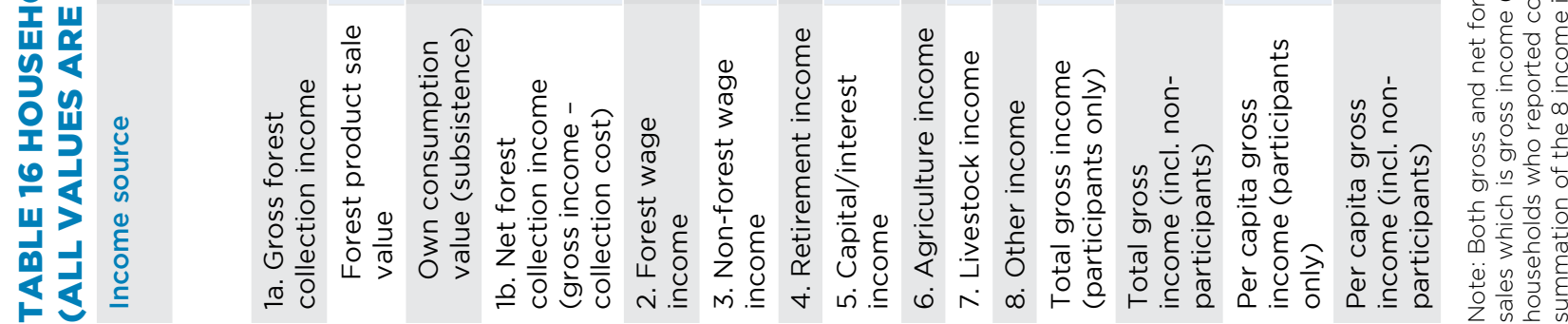


Across all regions, and based on the household participation rate, forest collection is the most important income source, as about 61 percent of households generated income from either selling forest products, consumed forest products or a combination of both; although only 4 percent of households had forest wage income. The next important income source was pensions (38 percent), followed by income from agriculture (25 percent), the sale of livestock and livestock products (25 percent), and non-forest wage income (16 percent). This pattern of participation rates is fairly consistent across the four strata as well - with the exception of agriculture or livestock income switching ranks in some instances.

Ranking income sources by the level of income is more complicated due to the fact that households engaged in different income generation activities and many extreme income values are reported across income sources (i.e. outliers). The income level by source is therefore measured using both average and median income in order to mitigate the influence of outliers. These outliers substantially skew the average forest collection income as illustrated in the large differences between mean and median forest related income reported in Table 16.

The ranking of income sources based on median income shows that non-forest wage income and retirement income are the most important sources, followed by agriculture or livestock, and capital/ interest income (covering income from real estate and interest earnings). Capital or interest income was only reported by about 2 percent of all households. If we use the mean to rank income, agriculture is the most important source, followed by capital/interest income, non-forest wages and retirement income. It is interesting to note that households, on average, earn about the same level of income from non-forest wage income and retirement income and this remains so across the 4 different poverty-migration strata. One exception is in high migration-high poverty areas where mean forest wage income is much higher - likely due to a few individuals receiving much more since the median value is much lower than in any other region.
Table 16 also shows that the average per capita income of participant forest village households (9,330 TL per capita) is significantly lower than the national per capita income in $2016(29,800$ $T L$ per capita). The average earnings of Turkish citizens is more than 3.2 times the average forest villager. Among all households surveyed, about 84 percent lived below the national poverty line $(1,115$ TL / per head per month (Türkiş, 2016)), confirming an extremely high incidence of poverty across all forest villages.

Figure 16 shows that households collected a diverse range of forest products. About 54 percent of households collected firewood, but only 1 percent engaged in industrial wood operations. Households reported collecting some 70 different products, with mushrooms, herbs, thyme, rosehips and pinecones being the more popular non-wood products collected in the forest.

\section{FIGURE 16 PERCENTAGE OF HOUSEHOLDS COLLECTING FOREST PRODUCTS}
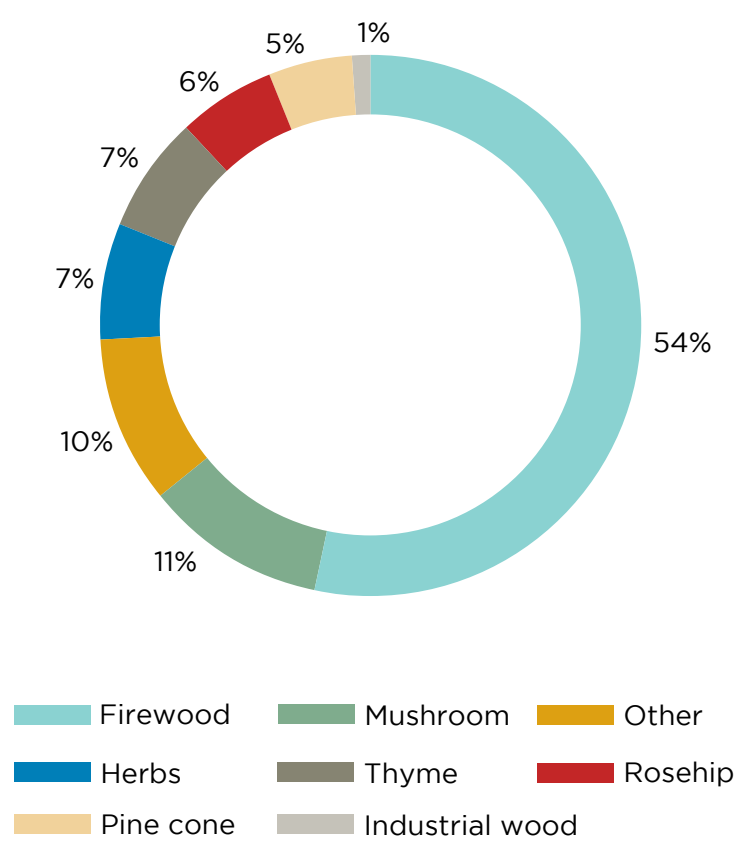

NOTE: Households collected 70 different types of products. For this chart - only products collected in the forest, and collected by at least 10 households were used. 'Other' products include: Sage, Hazlenut, Linden, Stingnettle, Walnut, Chestnut, Blackberry, Trefoil, and Opium. 


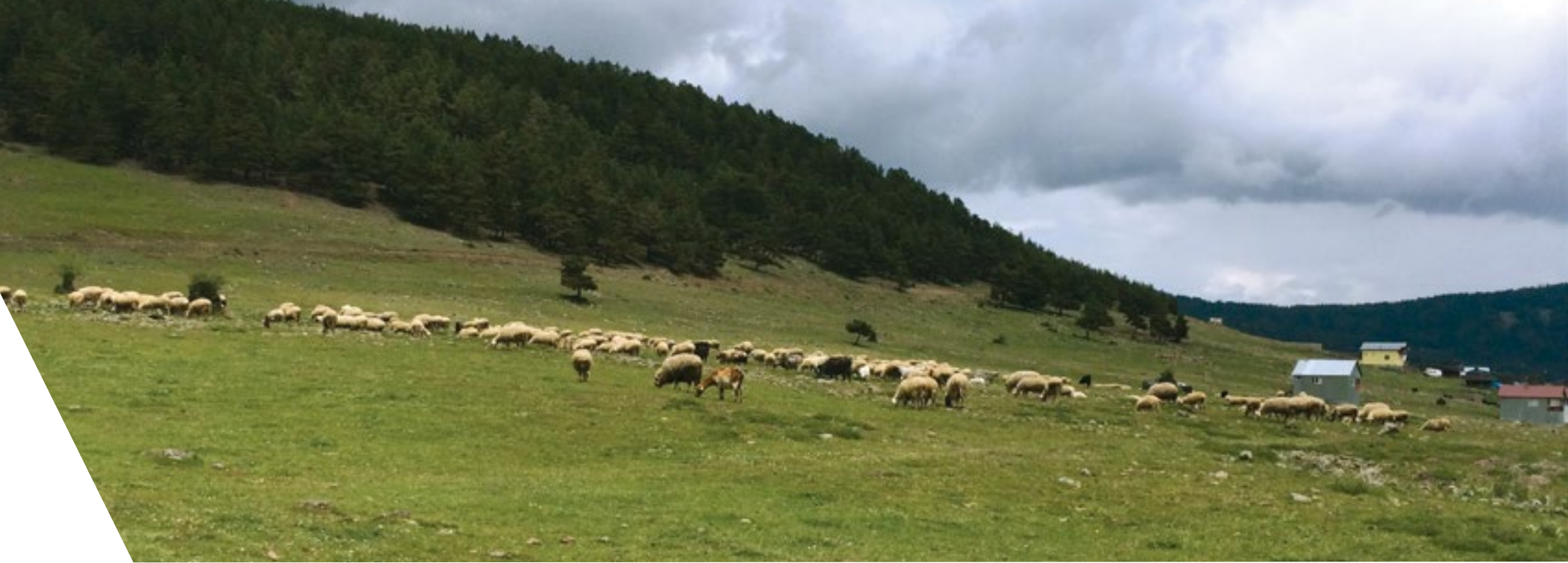

Table 17 presents the summary of sale value of individual products, including both forest wood products, NWFP, and agricultural and horticultural products. The reported sale values are also featured with extreme values. Using the median sale measure, the industrial wood appears extremely profitable, although only 16 households engaged in industrial wood sale. Among the nonforest products, tobaccos is the most profitable, followed by tea, olives and apricot. About 16 percent of households in the sample villages obtained income from selling forest products, of which 150 also collected NWFPs for sale.

The median gross sale of NWFP sale at $600 \mathrm{TL}$ (per household over past 12 months), although higher than forest collection sale (400 TL), is much lower than other income sources. Given Turkey is considered well-endowed in NWFPs, this suggests that there exists enormous potential to improve the income sources from NWFPs. Returns from NWFPs can be increased by both improving the productivity of NWFP harvesting and increasing value added through developing local small-scale processing industries. Currently, only 20 percent of NWFPs are processed before exporting. Thus, targeting ORKOY programs to help forest villages to develop the local capacity to process NWFPs, particularly related to olive oil production and the sale of different herbs, may potentially boost income and employment.
TABLE 17 AVERAGE ANNUAL HOUSEHOLD SALES OF PRODUCTS (TL)

\begin{tabular}{|l|r|r|r|}
\hline & Mean & Median & No of HH \\
\hline \multicolumn{4}{|c|}{ Non-wood forest products (NWFP) } \\
\hline Mushroom & 100 & 48 & 229 \\
\hline Herbs & 2,398 & 50 & 125 \\
\hline Thyme & 45 & 12 & 132 \\
\hline Rosehip & 128 & 90 & 115 \\
\hline Pinecone & 3,231 & 250 & 94 \\
\hline Total (NWFP) & 6,491 & 600 & 269 \\
\hline
\end{tabular}

\begin{tabular}{|l|r|r|r|}
\hline \multicolumn{4}{|c|}{ Wood forest product } \\
\hline Firewood & 447 & 250 & 1,085 \\
\hline Industrial wood & 36,032 & 34,200 & 16 \\
\hline
\end{tabular}

\begin{tabular}{l|r|r|r|}
\hline \multicolumn{4}{|c|}{ Agricultural and horticultural product (AHP) } \\
\hline Olive oil & 13,874 & 3,300 & 141 \\
\hline Wheat & 8,957 & 1,125 & 79 \\
\hline Barley & 2,874 & 700 & 56 \\
\hline Olive & 5,728 & 3,450 & 50 \\
\hline Tea & 10,676 & 6,800 & 44 \\
\hline Apricot & 8,126 & 3,700 & 35 \\
\hline Fig & 6,787 & 1,250 & 29 \\
\hline Beetroot & 198,161 & 15 & 27 \\
\hline Cherry & 3,218 & 1,500 & 27 \\
\hline Bean & 222 & 163 & 26 \\
\hline Potato & 6,246 & 150 & 25 \\
\hline Tomato & 5,638 & 25 & 23 \\
\hline Medlar & 50 & 30 & 21 \\
\hline Apple & 433 & 163 & 20 \\
\hline Tobacco & 31,534 & 24,000 & 16 \\
\hline Corn & 4,962 & 800 & 14 \\
\hline Total (AHP) & 21,087 & 2,400 & 492 \\
\hline
\end{tabular}


c) Income Diversification and Forest Dependency How do forest villagers diversify their income sources and to what extent do their livelihoods depend on forest-related activities? Income diversification captures an important aspect of household welfare and poverty, because it reveals household's resilience to shocks as well as their capability to expand opportunities to improve their livelihood beyond the forest. Such information is valuable for guiding policies that aim to effectively target poor households and support their movements out of poverty by enhancing productivity and income diversification.

The analysis of income source diversification is based on the seven principle income sources listed in Table 16. Figure 17 presents the distribution of the number of income sources which captures the degree of income diversification in forest villages. The results show that about 40 percent of forest-village households participated only in one income activity, while 55 percent and 30 percent of households engaged in two and three activities, respectively. Cumulatively, about 98 percent of households participated between one to four activities.

\section{FIGURE 17 INCOME DIVERSIFICATION}

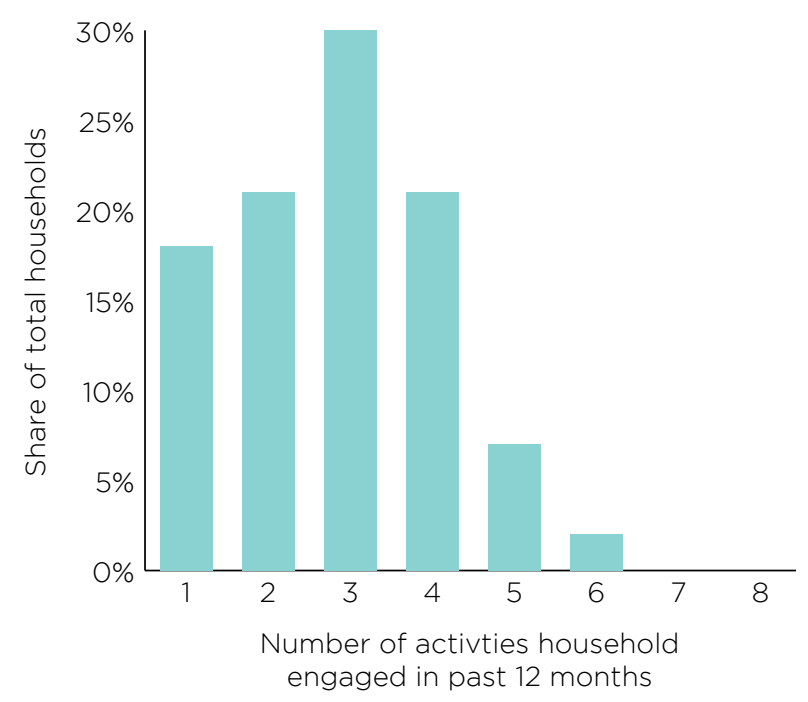

Note: Households can receive income from 7 potential activities, including: forest product collection, forest employment, nonforest employment, livestock sales, capital interest, pension, and other non-forest related sources.
What are the household income-earning strategies? Figure 18 presents household's choices of income combinations based on the seven most popular income sources. The analysis focuses on single income source to capture vulnerability (or lack of diversification) as well as the combination between forest-related income and other income sources to highlight forest dependency. These include (1) income source only from forest-related activities (2) only from non-forest wage (3) only from agriculture or livestock (4) only from pensions (5) combination of forest income with either agriculture/livestock, (6) combination of forest income with agriculture/livestock and pension and (7) the rest of permutation excluded in (1)-(6)). ${ }^{54}$

\section{FIGURE 18 MOST POPULAR COMBINATION OF INCOME SOURCES ( PERCENT OF HOUSEHOLDS)}

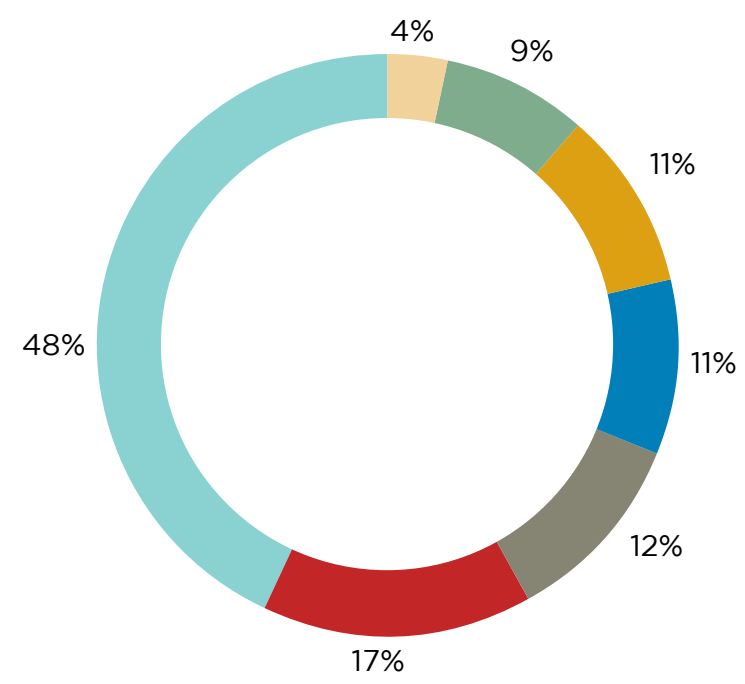

Non-forest related employment only

Pension only

Forest related activities, Pension, and Agriculture and/or Livestock

Forest related activities only

Forest related activities and Agriculture and/or Livestock

Rosehip

Other combinations

54. The combinations of income sources are numerous, but also include such combinations as: forest income + non forest wage; nonforest wage + agriculture / livestock; non forest wage + pension; and agriculture / livestock + pension + non forest wage. 
The distribution of the income source combination presented in Figure 18 shows that forest households concentrated somewhat equally in agriculture and livestock production than forest-related activities. On average, about 16 percent households engaged solely in agriculture or livestock for income generation, 14 percent households depend only on forest income, while 6 percent households only on pension income. Overall, about 12 percent of households supplemented forest income by engaging in agriculture/livestock activities, and 10 percent by both agriculture/livestock sales and pensions. The majority of households in forest villages (43 percent) depend on a highly diversified portfolio of income sources - with the most common combinations being from forests, agriculture, livestock, pensions and non-forest wage income.

The analysis of households' choices of income sources provides strong evidence that non-forest wage jobs are very limited across forest villages, with less than 4 percent of households depend their livelihoods solely on non-forest wage income. Nonforest wage income is 3-4 times higher than forest wage income (median in Table 16), this may suggest that programs focus on improving the productivity of forest wage jobs as well as expanding nonforest employment opportunities. In particular, the policies should focus on developing SMEs both for NWFPs such as processing and packaging for export, and wood products such as furniture manufacturing. More importantly, supporting local communities to connect to the supply value chain is critical.

Table 18 presents the distribution of household's choice of income sources for all villages, and separately for villages in the four strata. The analysis of the income portfolio by stratum also confirms the above findings. Households in high migration, high poverty villages are more dependent on the forest, with about 18 percent households deriving income only from forest-related activities, in comparison with the low poverty strata (about 11 percent for HM-LP, and 13 percent for the LM-LP strata). This finding may indicate a correlation between poverty, forest dependency and limited options for economic diversification, i.e. a poverty trap. Therefore, development programs should aim to break the poverty trap through targeted interventions, such as enhancing the productivity of forest related jobs through investment in forest management equipment, skill training, and expanding employment opportunities through connecting the local economies to production supply value chain.

\section{TABLE 18 INCOME EARNING STRATEGIES AND FOREST DEPENDENCY ( PERCENT)}

\begin{tabular}{|l|r|r|r|r|r|}
\hline Income choice & All villages & LM-LP & LM-HP & HM-LP & HM-HP \\
\hline Forest income only & 11.1 & 12.9 & 1.7 & 15.2 \\
\hline Non-forest wage only & 3.8 & 2.6 & 10.0 & 1.4 \\
\hline Agriculture or livestock & 16.9 & 17.3 & 8.3 & 15.9 & 19.6 \\
\hline Pension income only & 8.8 & 7.9 & 6.7 & 7.9 & 5.3 \\
\hline Forest + (ag or livestock) & 12.3 & 14.5 & 5.0 & 13.1 & 13.3 \\
\hline Forest + (ag or livestock) + pension & 10.5 & 11.0 & 21.7 & 10.9 & 11.3 \\
\hline Other combinations * & 48.1 & 47.6 & 51.7 & 53.2 & 42.4 \\
\hline All combined & 100.0 & 100.0 & 100.0 & 100.0 & 100.0 \\
\hline No of Households & 1818.0 & 456.0 & 60.0 & 662.0 & 495.0 \\
\hline
\end{tabular}

Note: * Such as those in footnote 54. 
d) Outside Support (GDF/ORKOY/Cooperatives) Despite the long history of government support through establishing forest dependent cooperatives and associations in forest villages, the survey data shows the coverage of membership is relatively low. While about 6 percent of households surveyed were members of forest dependent cooperatives and associations, over 18 percent were members of other cooperatives. The average tenure of forest dependent and other cooperatives was about 14 and 12 years, respectively.

Among the members of forest dependent cooperatives (total 119 households), about 16 percent of households reported to have received employment from the cooperative, which is higher than members of other cooperatives (about 13 percent of households received employment). Only 11 households reported receiving a loan in 2016, ranging from 1,000 TL to 50,000 TL, with an average of 16,800 TL $(\$ 6,216)$, and 18 households reported employment.

Among the 108 villages (out of 203 total villages surveyed), about 34 percent of villages reported a benefit directly to the household over the past 12 months, 6 percent received a village level development project, and 14 percent received both household and village level program benefits, while about 46 percent villages did not receive any benefits (in cash or in kind).

Among those villages who did receive support, it was mostly in the form of training and technical assistance, and free seedlings from GDF and other public institutions. Among the 59 villages that collected this information, they received information and education about forest policies and laws (72 percent), training in forest management
(45 percent), technical assistance for forestry practices (37 percent), training in forest product processing (27 percent) and free seedlings (25 percent).

\section{e) Migration}

The high migration rate among forest households poses a major problem in forest communities, leading to a labor shortage. The on-going outmigration makes it difficult to sustain the level of local labor force required to maintain forest management and support the livelihoods of the local population through more diverse economic activities. This section focus on three issues associated to migration, including (1) the reasons for migration, (2) how household socio-demographic characteristics and income diversification strategies vary by migration status and (3) which factors affect the probability of migration. The analysis examines possible linkages between migration, economic diversification and poverty, with the objective of providing evidence to guide policies that can effectively enhance household income generation capacity while balancing migration and promoting economic diversification in forest communities.

Forest village households can be classified into three groups based on their migration status, including households with at least one permanent migrant, those who intend to migrate (or potential migrant households) and those with no migrants. Table 19 presents a summary of household distribution by migration status for all villages as well as by stratum. Over half of households surveyed had permanent migrant members or those who intend to migrate. Even in low migration, low poverty areas, only half of households (51 percent) have no permanent migrants and do not intend to migrate.

\section{TABLE 19 THE DISTRIBUTION OF HOUSEHOLD MIGRATION STATUS BY STRATUM (PERCENT)}

\begin{tabular}{|l|r|r|r|r|r|}
\hline Household migrant status & All villages & LM-LP & LM-HP & HM-LP & HM-HP \\
\hline With permanent migrants & 37.6 & 35.0 & 43.9 & 39.6 & 40.6 \\
\hline With members who intend to migrate & 14.1 & 13.3 & 12.0 & 14.9 & 13.5 \\
\hline No migrants & 48.4 & 51.7 & 44.1 & 45.5 & 45.9 \\
\hline All HH & 100.0 & 100.0 & 100.0 & 100.0 & 100.0 \\
\hline
\end{tabular}


TABLE 20 VILLAGE OUT-MIGRATION RATE (PER 1000 PERSONS)

\begin{tabular}{|l|r|r|r|r|r|}
\hline & \multicolumn{4}{|c|}{ Village Migration Rate, per 1000 people } \\
& All Villages & $\begin{array}{r}\text { Low migration, } \\
\text { low poverty }\end{array}$ & $\begin{array}{r}\text { Low migration, } \\
\text { high poverty }\end{array}$ & $\begin{array}{r}\text { High migration, } \\
\text { low poverty }\end{array}$ & $\begin{array}{r}\text { High migration, } \\
\text { high poverty }\end{array}$ \\
\hline Total for all reported years & 223.77 & 176.87 & 223.61 & 276.31 & 12.98 \\
\hline In the past 1 year & 15.77 & 15.87 & 33.01 & 16.45 & 26.17 \\
\hline In the past 3 years & 33.06 & 32.75 & 53.75 & 36.88 \\
\hline In the past 5 years & 54.16 & 50.30 & 65.72 & 56.05 & 54.55 \\
\hline In the past 10 years & 105.16 & 104.94 & 108.36 & 105.35 & 104.82 \\
\hline Total Villages & 203.00 & 62.00 & 6.00 & 77.00 & 58.00 \\
\hline
\end{tabular}

Source: World Bank, 2016

Note: Interpretation: rate of out-migration per village per 1000. Plutocratic ratio = total migrants per village/village pop.

Rates of migration vary across Turkey depending on the economic and social conditions in each forest village. In the survey's sample design, the official rates of migration from TUIK were used to stratify (divide) different regions of Turkey to look for patterns among forest villages. Rates of migration also vary across time largely for the same reasons, so in the reporting we account for this by looking at the rates of out-migration over different periods of time.

The rate of out-migration among forest villages in the past year was 15 per 1000 persons which appears to be low, however if one lengthens the analysis to 10 years this rate increases exponentially to over 100 per 1000 (Table 20). This rate is much higher than the average rate of out-migration (46.2/1000) from 2014-2015 across all provinces of Turkey (TUIK, 2016). Within high migration areas, richer areas have more permanent migrants and poorer areas have more households who indicated they may migrate in the future.

\section{i) Reasons for Migration}

Among households with members who have already migrated, referred to as permanent or long-term migrant households, finding a job is the most common reason for migrating (Table 21). But when looking at each stratum separately, we find that there are differences between low and high migration villages. In the former, individuals more often leave for marriage (55 percent), whereas in high migration areas, most often, people leave for work (56-67 percent). Permanent migrants, whether they left for work or marriage, have been away for an average of 11 years.

Households who indicated they would like to migrate state that it is the inability to subsist rather than a lack of jobs that motivate them. These potential migrant households make up almost a fifth of households in poor/high migration areas. The difference in motivations for migration between high and low migration areas is further supported by a remarkable variation in the belief that the current state of forest resources can meet their living needs; only 32 percent of households in poor, high-migration areas are satisfied, as opposed to 78 percent in low-migration areas. Roughly 17 percent of migrants remit small amounts back to their homes. On average, migrants send below 500 TL (\$170) back home.

At the time of the survey, the net unemployment rate among forest villages was around 11 percent. While higher numbers have been reported in other documents, this is likely more of a reflection of the "underemployment" felt in these areas. ${ }^{55}$ The official unemployment rate in Turkey is 9.3 percent (TUIK, April 2016).

55. While only 5 percent of respondents stated they were unemployed, the actual unemployment rate was 14 percent when the labour force was defined as the sum of those employed and unemployed. 
TABLE 21 REASONS FOR MIGRATION ( PERCENT)

\begin{tabular}{|c|c|c|c|c|c|}
\hline & All Villages & $\begin{array}{l}\text { Low migration, } \\
\text { low poverty }\end{array}$ & $\begin{array}{l}\text { Low migration, } \\
\text { high poverty }\end{array}$ & $\begin{array}{l}\text { High migration, } \\
\text { low poverty }\end{array}$ & $\begin{array}{l}\text { High migration, } \\
\text { high poverty }\end{array}$ \\
\hline \multicolumn{6}{|c|}{ Permanent Migrants (Reasons for migrating) } \\
\hline Job search & 52 & 33 & 30 & 56 & 67 \\
\hline Marriage & 36 & 55 & 55 & 31 & 24 \\
\hline Education & 4 & 4 & 12 & 4 & 3 \\
\hline Observations & 1259 & 331 & 33 & 588 & 307 \\
\hline \multicolumn{6}{|c|}{ Potential Migrants (Reasons for migrating) } \\
\hline Difficult to subsist & 58 & 54 & 50 & 55 & 66 \\
\hline No jobs & 23 & 26 & 17 & 24 & 19 \\
\hline Education & 7 & 8 & 0 & 13 & 2 \\
\hline Observations & 310 & 76 & 6 & 103 & 111 \\
\hline \multicolumn{6}{|c|}{ Can current state of forest resources meet your living needs? } \\
\hline Yes & 62 & 80 & 78 & 66 & 33 \\
\hline Observations & 2033 & 646 & 60 & 775 & 549 \\
\hline
\end{tabular}

TABLE 22 HOUSEHOLD SOCIO-DEMOGRAPHIC PROFILE BY MIGRATION STATUS

\begin{tabular}{|c|c|c|c|c|c|c|}
\hline & \multicolumn{4}{|c|}{ Household head } & \multicolumn{2}{|c|}{ Household } \\
\hline & Age & \multicolumn{3}{|c|}{ Education attainment (percent) } & $\begin{array}{c}\text { No-prime age } \\
\text { members }\end{array}$ & Age dep ratio \\
\hline \multicolumn{2}{|l|}{ Household migrant status } & Dropout & Never in school & Mid and above & (percent) & (percent) \\
\hline have permanent migrants & 55 & 12 & 75 & 13 & 19 & 35 \\
\hline - within 10 years & 55 & 10 & 76 & 14 & 12 & 29 \\
\hline - 10 years ago & 56 & 15 & 72 & 13 & 31 & 46 \\
\hline Intend to migrate & 45 & 8 & 61 & 31 & 2 & 54 \\
\hline No migrants & 49 & 7 & 69 & 24 & 11 & 46 \\
\hline All $\mathrm{HH}$ & 51 & 9 & 70 & 22 & 13 & 43 \\
\hline
\end{tabular}

11) Differences in Socio-demographic Characteristics and Income Sources by Migration Status

Table 22 presents the summary of the age and education attainment of the household head, as well as household demographic structure by migration status. The latter is summarized by the proportion of households with no working age members left at home and the age dependency ratio. The results show that the head of household, among those who stated they intend to migrate, are much younger, and more educated than those with permanent migrants. About one third of households with permanent migrants who left 10 years ago have no prime working age members living in the household, compared with 12 percent among those who permanently migrated within past 10 years. Thus migration is a serious issue leading to a labor shortage in forest communities.

Given that the majority of migrants (97 percent) are sons or daughters, the age gap between household heads suggests there could be a cohort effect since the average age is 45 for those intending to migrate, 49 for no migrants and 55 with migrants. That is, households with no permanent migrants may be due to the fact that they are younger households with children too young to work outside villages. Thus, migration might be an inevitable consequence with children leaving villages when they reach the prime working age. It is also striking 
to observe that about one fifth of households (19 percent) with permanent migrants have no primeworking age members left at home. This suggests that migration is the major cause of labor shortages in these villages.

The survey reveals that the lack of job opportunities, and thus income, is one of the most important reasons for migration. Table 23 presents average income by source across migration status. Households with permanent migrants have a much higher level of per capita income $(12,028 \mathrm{TL})$ than no-migrant $(8,030 \mathrm{TL})$ and potential migrant households (5,749 TL). This is likely a reflection of household size and indeed, the average household size among migrant households is smaller (2.9) than non-migrant households (3.6) and those intended to migrate (4.4), which contributes to higher per capita income.

While there is little variation in forest income among households of different migration status, households with permanent migrants have lower income from livestock sales, but higher agriculture income compared to no-migrant households. No-migrant households have a significantly higher income from non-forest related activities - the average non-forest wage, pension income, agriculture and livestock income. This may suggest a negative association between household's income generation capacity outside forest and the propensity to migrate, i.e. households who are more capable of generating income from agriculture and livestock, are less likely to send members seeking jobs outside. ${ }^{56}$

III) Identification of Key Factors Affecting Household Migration

Identifying factors that determine household migration would be important to know from a policy perspective. Household's migration decisions are closely related to household income as well as their income diversification strategies, which are, in turn, influenced by many key factors both at the household and village level. In addition, forest development programs and cooperatives supported by ORKOY can also have an impact on household's economic opportunities, their livelihood strategies, including the migration decision. While it is challenging to identify all of the pathways through which these variables may affect the migration decision, the household survey presents an opportunity to explore the potential key factors using an econometric model.

The econometric model aims to estimate the effect

\section{TABLE 23 AVERAGE INCOME BY HOUSEHOLD MIGRATION STATUS (TL)}

\begin{tabular}{|l|r|r|r|r|r|}
\hline & & & Household migration status \\
\hline Income source & & Permanent migrants & Potential migrants & No migrants & All households \\
\hline Forest collection & Mean & 2,111 & 2,098 & 2,229 & 2,158 \\
\hline Forest wage & Median & 480 & 435 & 360 & 13,762 \\
\hline Non-forest wage & & 13,287 & 14,158 & 13,813 & 16,709 \\
\hline Retirement pension & 16,320 & 16,005 & $17,064 \mid$ & 15,446 \\
\hline Agriculture & 14,961 & 14,755 & 16,049 & 28,798 \\
\hline Livestock & 37,049 & 14,411 & 24,770 & 11,959 \\
\hline Other income & 9,473 & 11,510 & 13,928 & 8,656 \\
\hline Total income & 9,135 & 9,219 & 7,932 & 26,250 \\
\hline Per capita income & 29,635 & 19,916 & 25,301 & 9,259 \\
\hline No of households & 12,028 & 5,749 & 8,030 & 1,021 \\
\hline
\end{tabular}

56. Indeed, through personal communication during survey implementation - several households indicated that they had purchased livestock as an incentive to keep the young from leaving home. In some cases, it worked. 
of key variables on the probability to migrate, controlling for household- and village-level characteristics (e.g. infrastructure, access to basic services and government supported programs). ${ }^{57}$ Of further interest is the potential effectiveness of development programs in forest villages on migration. Thus the model also includes three policy-related variables, including membership in forest-related cooperatives and associations, forest income dependency (measured by forest income share) and income diversification strategies (measured by non-forest wage income share).

It is also important examine how the impact of policies on migration varies over time by distinguishing between recent migrant households (within 5 years of at the time of survey, 2011-2016) and those with migrants who left long time ago (say, between 2005-2010). The household survey shows that about 13 percent households had at least one permanent migrant during the past 5 years, and 11 percent during the early 5-year period (20052010), indicating an upward trend to migration.

The empirical results (presented in Appendix 4) show that two variables, membership of forest cooperatives and associations and forest dependency have a statistically significant impact on the probability of migration, after controlling for other factors. Households that belong to forest cooperatives and associations are more likely to stay in forest villages.

This migration 'reduction effect' of membership is only significant within the past five years (i.e. there is no effect on migration in the five-year period 20052010). This may indicate that some of the benefits received by households from forest cooperatives and associations, either in the form of credit or employment, has made an impact on the migration decision only in recent years. Coincidently, the timing also aligns with the restructuring of FDGVR in 2011 when it was replaced by ORKOY, as part of GDF, with the objective to contribute to the development and attainment of production targets of forests through implementing a variety of socio-economic programs. However, it remains unclear whether the impact on migration is due to an improvement of program implementation or other macro-level factors such as the improvement in employment opportunities in forest village communities over time. It would be important to further explore the underlying reasons of the beneficial impact of membership, although this would involve a more detailed assessment of programs implemented by forest associations and cooperatives.

With regard to the forest dependency variable (share of forest income), the results show that households who are more dependent on forests for income are more likely to have permanent migrants in the family. The result remains consistent over the past 10 years. This finding is consistent with the stated reasons for migration in Table 21, confirming that forest income is insufficient to support household's livelihood and, hence, households with limited options other than forest resources have to resort to sending family members to seek jobs outside as a coping strategy.

While there exists ample scope to further modify the model's specification, the empirical findings are robust. The estimated coefficients from the econometric model could be used to perform policy simulations to illustrate the impact of various policy proposals on migration.

For example, Table 24 presents an illustration of a policy simulation on the migration impact of a hypothetical policy proposal that aims to expand membership of forest cooperatives to cover all forest villagers. The survey data shows that currently only about 6 percent of households belonged to forest cooperatives and associations, and the estimated probability of households with permanent migrants within a 10-year period is 36 percent. If membership were expanded to all forest village households, the migration probability falls to 29 percent, while the no migration case increases to 57 percent, i.e. a potential reduction of 17 percent out-flow of population. Using the

\footnotetext{
57. Probability (migration) $=f\left(X_{h h}, W_{\text {village, }}\right.$ Policy variables), where $X_{h h}$ are household variables including age, education of household head, household income; Wvillage are village-level characteristics including village infrastructure; and Policy variables including membership of forest cooperative, membership of other cooperatives, and forest dependency (measured by the share of forestrelated income).
} 
official 2014 population data, this simulation shows that about 500,000 people (or 7 percent of forest village population in 2014) could have stayed in the villages. While the results should only be used for illustrative purposes, this simulation shows the potential impact of policy reform in forest development programs on household migration decisions.

\section{TABLE 24 ESTIMATED PROBABILITY OF MIGRATION AND POLICY SIMULATION

\begin{tabular}{|c|c|c|}
\hline & $\begin{array}{r}\text { Sample } \\
\text { mean }\end{array}$ & $\begin{array}{r}\text { Simulated } \\
\text { mean }\end{array}$ \\
\hline & & $\begin{array}{l}\text { (if all hh } \\
\text { become } \\
\text { member) }\end{array}$ \\
\hline $\begin{array}{l}\text { Percent HH being member } \\
\text { of forest associations }\end{array}$ & 5.8 & 100 \\
\hline \multicolumn{3}{|c|}{ Probability (percent) } \\
\hline Perm migration & 36 & 29 \\
\hline Intent to migrate & 16 & 15 \\
\hline Not migrate & 49 & 57 \\
\hline $\begin{array}{l}\text { Number of people leaving } \\
\text { within } 5 \text { years }\end{array}$ & $2,554,734$ & $2,057,980$ \\
\hline
\end{tabular}

Note: The official data shows that in 2014, there were 7,096,483 people living in forest villages.

Understanding the interlinkages between forest dependency, income diversification and migration decisions warrants further investigation and needs to take into account economic factors at the household and community level as well as the role of forest development programs. In particular, information on how public programs supported by ORKOY could be targeted to effectively support households in improving productivity and income diversification. These policies would also need to be consistent with those under other Ministries as well, namely policies that address high poverty incidence and migration.

\subsubsection{Conclusions}

The findings from the household survey provides important insights into livelihood strategies as well as linkages between income generation opportunities, forest dependency and migration decisions among forest village households. While the income sources among households in forest communities are relatively diverse, the majority of households engaged in low productivity, low paid activities, such as sale of forest products, and supplementing forest income through agricultural and livestock activities with returns significantly lower that non-forest wage jobs. As a result, about 80 percent forest households live below the national poverty line in 2016. The household survey presents some evidence of a poverty trap, i.e. majority households are trapped in vicious links between poverty, forest dependency and limited options for economic diversification into higher, more productive non-forest wage jobs.

The high poverty incidence among village communities is one of the driving forces underlying the rising trend of migration. On the other hand, migration has posed a major challenge to sustain the livelihood of forest communities: among households with permanent migrants, about onefifth have no prime working age members left in the household. The serious labor shortage has become a major obstacle for meeting the demand for sustaining forest management and diversifying local economies. However, the findings from the survey presents some encouraging evidence, indicating that targeted forest development programs such as those implemented by ORKOY can have a significant impact on reducing migration propensity. The program impact became significant since 2011 when ORKOY was established as a GDF department to resume the role and responsibilities of GDFVR. 
The evidence from the survey analysis also suggests that public policies and development programs should aim to break the poverty trap while addressing migration issues through targeted interventions. Two key components of the policy intervention should be highlighted. First, enhancing the productivity of forest related jobs through investment in forest management equipment, skill training, and infrastructure development. This should be complemented by an increase of the compensation of forest wage jobs through a greater budget allocation by the GDF.

Secondly, expanding non-forest wage employment opportunities through connecting the local economies to production supply value chains. In particular, policies should focus on developing SMEs for NWFPs such as processing and packaging for export, while supporting local communities to connect to the market. In the internet era, connecting supply chain trade through e-commerce has transformed the marketplace across the globe, and become the new engine for growth and job creation. The success stories from other countries can be replicated in Turkey in order to realize the huge potential presented in the forest sector as pathway to promote sustainable employment and improve the welfare of local communities.

While the analysis provides some evidence of the impact of forest dependent cooperatives and associations on migration, further analysis is warranted to delve deeper into the significance of the relationships between these issues. It would be important to identify policies and programs that would be most effective in increasing the valueadded from forest-related income activities while balancing migration and promoting economic diversification among forest communities. Strategies may vary by different strata as the issues may be different. But inherently the long-term goal is to achieve a win-win outcomes that ensure forest resource sustainability, biodiversity conservation, and improving the living standards of the forest dependent population.

\subsection{Climate Change and Biodiversity}

\subsubsection{Climate Change}

Turkey has a special position in the global climate change regime, which in turn influences its climate change law and policy. When the United Nations Framework Convention on Climate Change (UNFCCC) was established, Turkey was included in Annex I (developed countries) and Annex II (developing countries). Turkey objected to being listed as an Annex I or II party. It refused to sign the treaty and failed in its attempts to be removed from both Annexes. One of Turkey's main arguments in relation to the listings was that it was neither a fully developed country nor a country in economic transition. In 2000, Turkey changed its policy and sought to be removed from Annex II while remaining on Annex I (with special circumstances). The Conference of the Parties (COP) accepted this approach in 2001 but the term 'special circumstances' remains undefined. Although Turkey became a party to the UNFCCC in 2004, it maintains an expectation that the Annexes will be re-categorized on the basis of state social and economic levels. Turkey became a party to the Kyoto Protocol in 2009, but is not yet subject to emission reduction or limitation obligations. ${ }^{58}$

The GDF has been the national coordinator of Land Use Land Use Change and Forestry (LULUCF) since 2008 and prepares annual GHG inventories. The climate change working group (CC WG) in GDF has responsibility for policy and strategy formulation in relation to climate change.

In 2010 Turkey prepared its Climate Change Strategy (2010-2020) which sets out short, medium and long term measures for GHG emissions control across the various sectors including forestry. The forestry measures in the forestry focus on combating deforestation and forest degradation together with studies on climate change impacts on forest ecosystems and identifying and planting more drought resistant tree species. The area of climate change related activities undertaken between 2011 and 2016 are presented in Table 25.

58. Kayhan, A.K. Country Report Turkey: Turkey's Climate Change Dilemma. 5 IUCNAEL EJournal 270-276. 
TABLE 25 CLIMATE CHANGE ACTIVITIES 2009-2016 (HA) ${ }^{59}$

\begin{tabular}{|c|c|c|c|c|c|c|c|}
\hline Activity & $\begin{array}{r}\text { Up to and } \\
\text { including } 2011\end{array}$ & 2012 & 2013 & 2014 & 2015 & 2016 & Total \\
\hline Afforestation (from 1946) & $2,121,867$ & 42,009 & 46,656 & 40,325 & 38,986 & 48,230 & $2,338,073$ \\
\hline Rehabilitation (from 1998) & $2,144,964$ & 347,719 & 106,182 & 100,432 & 94,411 & 106,268 & $2,899,976$ \\
\hline Erosion control (from 1962) & 938,432 & 83,131 & 83,964 & 80,517 & 75,009 & 96,876 & $1,357,929$ \\
\hline Avalanche control & & & 340 & & 130 & 180 & 650 \\
\hline Range Improvement (from 1962) & 142,199 & 9,635 & 9,920 & 16,383 & 23,843 & 12,778 & 214,758 \\
\hline Special Afforestation (from 1986) & 116,638 & 4,944 & 1,975 & 3,984 & 3,012 & 3,245 & 133,798 \\
\hline Artificial Regeneration (from 1973) & 789,633 & 12,958 & 8,921 & 10,794 & 9,197 & 8,885 & 840,388 \\
\hline Energy Forest & 622,878 & - & - & - & - & - & 622,878 \\
\hline Total & $6,876,611$ & 500,396 & 257,958 & 252,435 & 244,588 & 276,462 & $8,408,450$ \\
\hline
\end{tabular}

\section{FIGURE 19 ESTIMATED NET EMISSIONS / REMOVALS ('OOOT)}

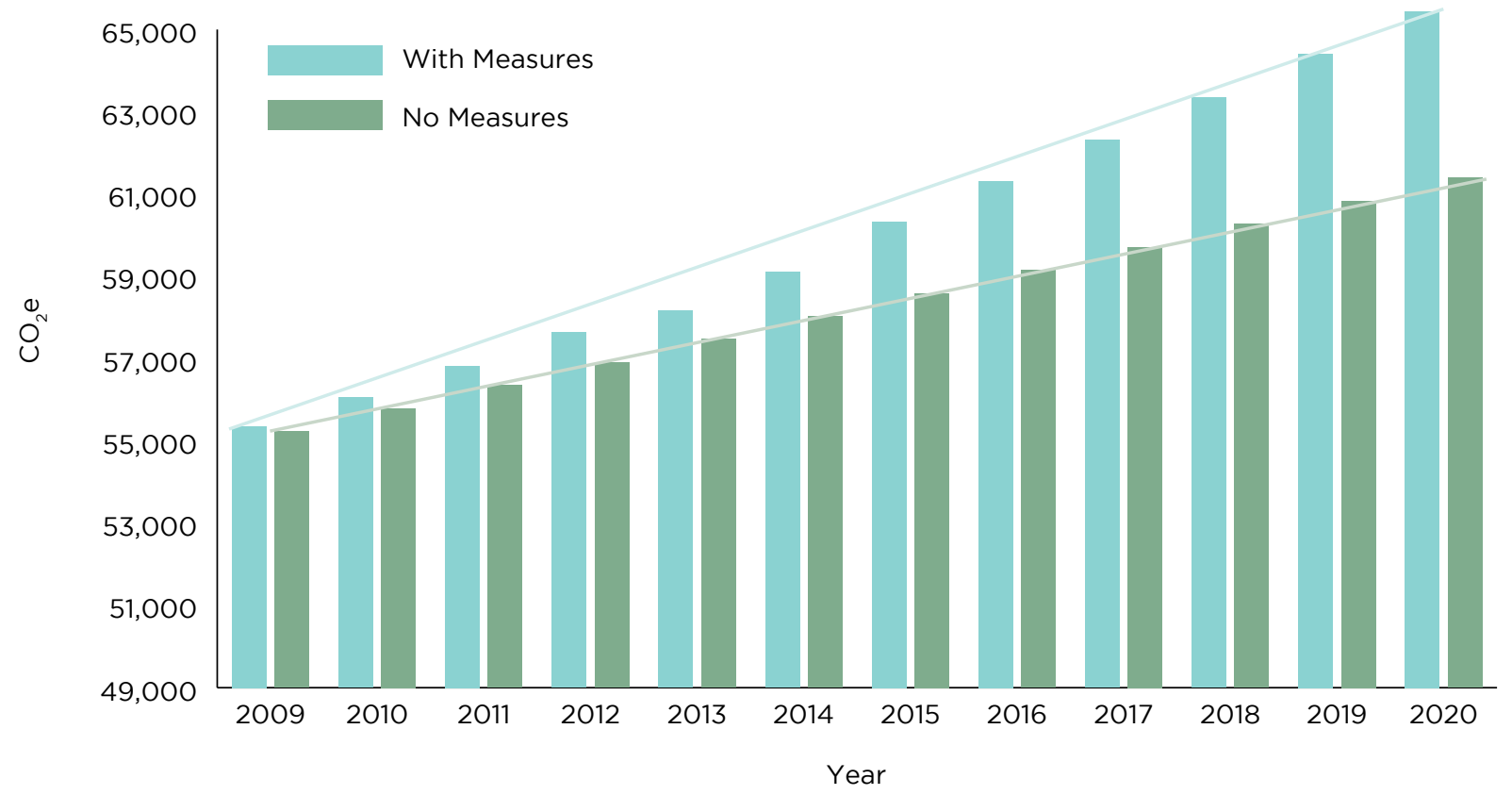

The Climate Change Action Plan, adopted in 2011, built on this strategy. This set out ambitious targets for afforestation and rehabilitation of degraded forests: 2.429 million ha afforestation, erosion control and rehabilitation within the scope of the National Afforestation Campaign started in 2008 and completed in 2012. As part of these activities, 2 billion seedlings were planted. The afforestation mobilization has rapidly afforested open areas, highway banks, schools, hospitals, local health centers and cemeteries. Targets in the main have been met including afforestation, erosion control and rehabilitation. Success is measured through seedling survival and this averages 85 percent for afforestation while for erosion control the success can be measured through reduced erosion and a reduction in the area subject to erosion. Seedling survival rates are lower than for afforestation.

Figure 19 shows the predicted additionality of the Climate Change Action plan on the net removal of emissions.

59. Climate Change Activities in GDF in Turkey (Mitigation and Adaptation). Caglar Bassullu 20th Session of Near East Forestry and Range Commission, 2012 Kemer/Antalya. 


\section{FIGURE 20 TURKEY'S GHG EMISSIONS TARGET UNDER THE INDC}

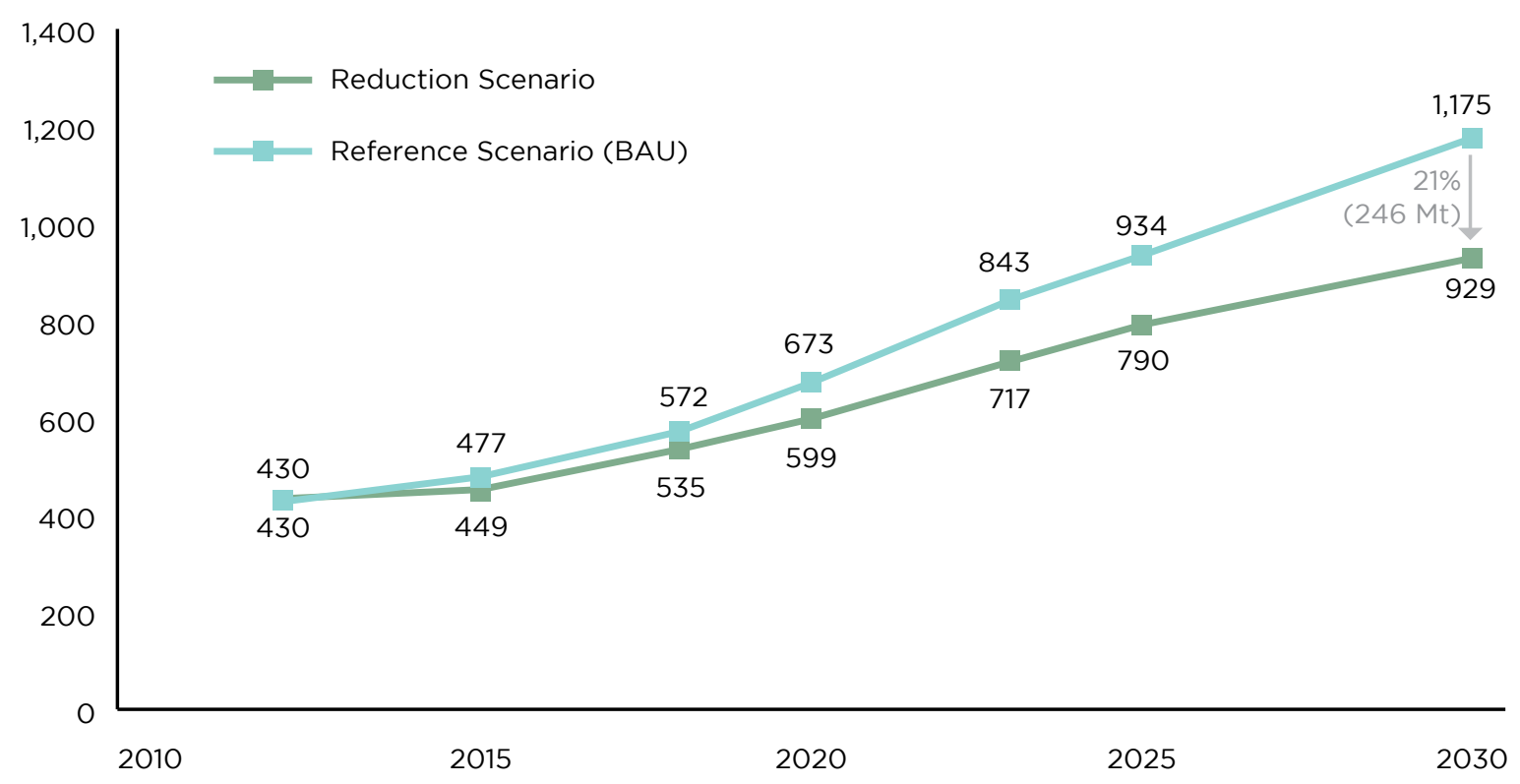

the impact of human-caused climate change on global warming below $2^{\circ} \mathrm{C}$ under the United Nations Framework Convention on Climate Change. The INDC is a document that contains the commitments and projections of countries based on reductions of national greenhouse gas emissions, similar to the Kyoto Protocol. INDCs or national contributions cover the period after 2020, when Kyoto Protocol expires.

The Ministry of Environment and Urbanization and TÜBITAK executed a joint Project to present Turkey's INDC. Under the Project, projections based on best and worst case scenarios were received from all sectors in the national greenhouse gas inventory for all years through 2030, and these projections were consolidated by TÜBITAK. The studies were conducted under the supervision of Climate Change and Weather Management Coordination Committee (IDHYKK), and finalized in the UN summit with the contributions of the Ministry of Foreign Affairs. The INDC was submitted to the UNFCCC Secretariat on September 30, 2015 and accepted as the 133 rd INDC by all submitting countries.
To achieve the INDC target, specific sectors have to undertake their own set of plans and actions to reduce their contribution to the country's total GHG emissions. This includes initiatives in such sectors as energy, industry, transport, buildings and urban transformation, agriculture, waste and forestry. Specific plans and policies for each sector are listed in Appendix 4. As a country, Turkey has committed to a 21 percent reduction in GHG emissions from the Business-As-Usual (BAU) level by 2030 (Figure 20).

The forestry sector is viewed as an important contributor to achieving the INDC target - but mainly through its carbon sequestration potential (i.e. the ability of the forest to absorb carbon dioxide). The INDC includes carbon sequestration projections for the forest sector, which is the most important carbon 'sink' area. The specific assumptions by the forestry sector to the two scenarios (i.e. BAU and Reduction) are: 


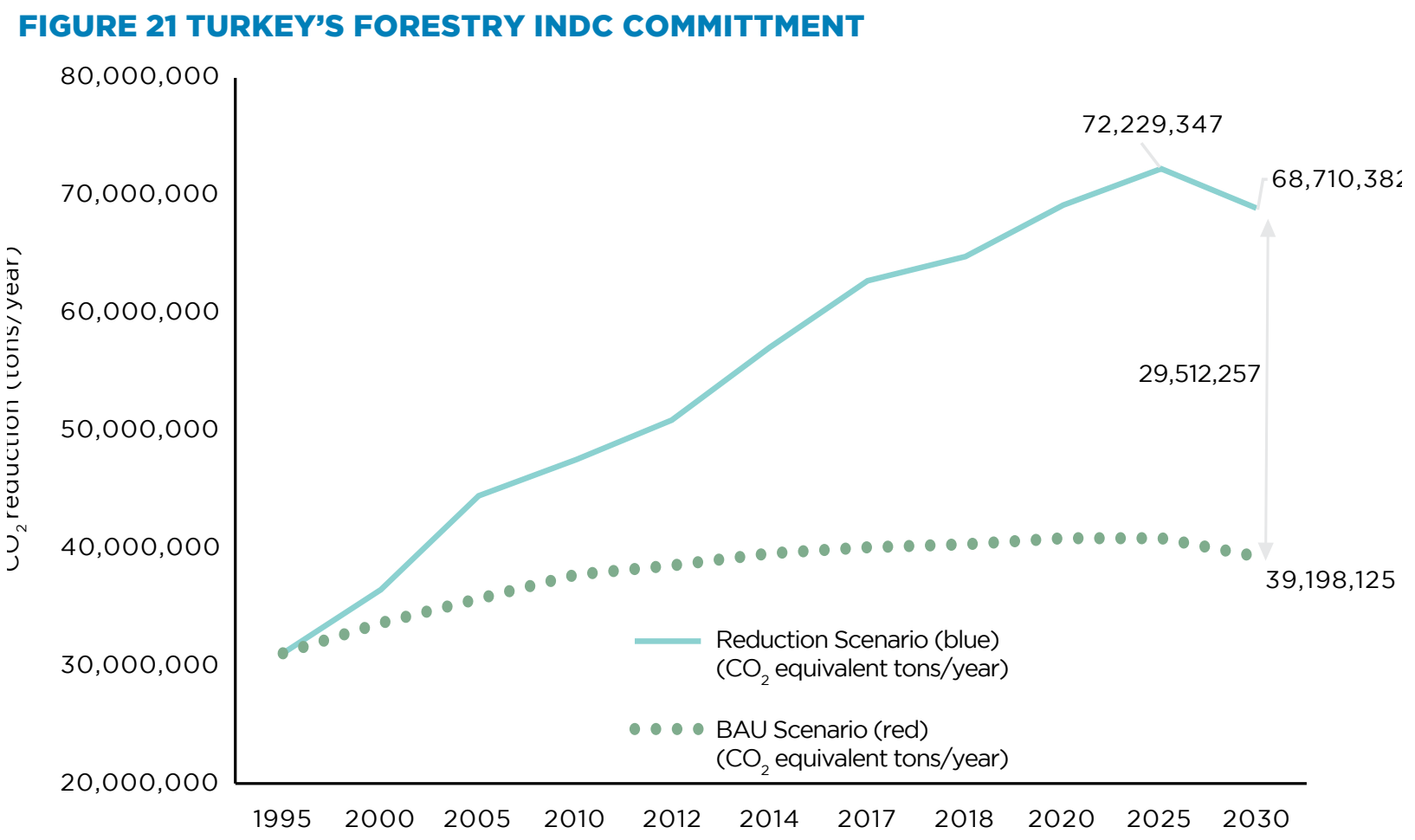

\section{Reduction Scenario}

- GDF 2013-2017 Strategic Plan, National Forestry Program (2004-2023) taken into consideration;

- GDF achieves the 2023 target (forest area 30 percent $=23.4$ million ha of the national territory);

- Productive forest area assumed to reach $12,000,000$ ha by 2030.

\section{Reference Scenario}

- Afforestation figures before 1996 (20,000 ha/ year) remain constant;

- Insufficient forest rehabilitation;

- Increased population and settlement pressure;

- Afforestation potential assumed to decline.
Under the BAU Scenario, emissions would fall by 39 million equivalent tons per year, representing approximately 3.23 percent of all emissions, and if targets are met under the Reduction Scenario, $\mathrm{CO}_{2}$ emissions would fall by 68.7 million equivalent tons per year - an additional 29.5 million equivalent tons by 2030 (Figure 21). If targets under the Reduction Scenario are realized this would represent a reduction of 6.89 percent of all emissions from all sectors and would constitute 12 percent of the 21 percent reduction target (Table 26). Thus the forestry sector would be one of the most important sectors in reducing carbon emissions in Turkey. 
TABLE 26 AMOUNT AND SHARE OF FORESTS IN INDC

\begin{tabular}{|c|c|c|c|c|}
\hline & \multirow{2}{*}{$\begin{array}{l}\text { Forest Areas and } \\
\text { Processed Forest } \\
\text { Products } \mathrm{CO}_{2} \\
\text { equivalent (ton) }\end{array}$} & \multicolumn{2}{|c|}{ Total GHG } & $\begin{array}{l}\text { Share of Forest Areas and } \\
\text { Processed Forest Products } \\
\text { in Total Emissions } \\
\text { Reduction, percent }\end{array}$ \\
\hline & & $\begin{array}{r}\text { Emissions } \\
\text { (all sectors) } \\
\mathrm{CO}_{2} \text { equivalent } \\
\text { (ton) }\end{array}$ & $\begin{array}{r}\text { Emissions } \\
\text { (excl. Forest Areas } \\
\text { and Processed } \\
\text { Forest Products) }\end{array}$ & \\
\hline & & & $\mathrm{CO}_{2}$ equivalent (ton) & \\
\hline $\begin{array}{l}\text { Reference Scenario } \\
\text { (Business-As-Usual) } 2030\end{array}$ & $-39,198,125$ & $1,175,000,000$ & $1,214,198,125$ & 3.23 \\
\hline Reduction Scenario 2030 & $-68,710,382$ & $929,000,000$ & $997,710,382$ & 6.89 \\
\hline $\begin{array}{l}\text { Reduction / Sink amount } \\
\text { (Difference) }\end{array}$ & $-29,512,257$ & $246,000,000$ & $216,487,743$ & \\
\hline $\begin{array}{l}\text { Reduction / (Sink Increment) } \\
\text { Amount (percent) }\end{array}$ & 75 percent & 21 percent & 18 percent & \\
\hline $\begin{array}{l}\text { Share of Forest Areas and } \\
\text { Processed Forest Products } \\
\text { in reduction commitment } \\
\text { (percent) }\end{array}$ & & 12 percent & & \\
\hline
\end{tabular}

\subsubsection{Biodiversity}

Turkey consists of three different bio-geographic regions, each with its own endemic species and natural ecosystems. These are (i) the Caucasian mountain forests with the temperate deciduous forest including alpine meadows, (ii) Central and Eastern Anatolian Steppe Grassland and (iii) the Mediterranean region. Climate and topography play an important role in maintaining the country's rich biodiversity.

Turkey has circa 11,707 plant species of which 3,649 are endemic ${ }^{61}$, some 161 species of mammals, 460 bird species, 716 fish species, and 141 reptile species. ${ }^{62}$ In addition, it has two of the three major flyways for migratory birds between the Western Palaearctic and Africa.

Biodiversity is the basis for all ecosystem services. The role of forests in maintaining diversity of habitats as well as species and genetic diversity is indisputable: of all environments, forests have the richest biodiversity provision. ${ }^{63}$
Forests are home to a wide range of flora and fauna and house significant portions of Turkey's natural biodiversity resource. In recent years forestecosystems have come under increasing pressure and many species and ecosystems are in danger through (a) the excessive use of forests in mountain ecosystems without considering their bearing capacity both at ecosystem and species levels (hunting, grazing, harvesting, tourism, in-forest construction activities, etc.), (b) the impacts of atmospheric pollution and global climate change, (c) pressures from communities living in and around forests on agricultural and forestry products (livestock, uncontrolled use, gaining farmlands and forest fires), (d) increasing construction due to tourism incentives, uplands tourism, the high number of visitors in the archaeological sites, (e) alien species, (f) over gathering of plants having an economical value, (g) mining activities and (h) improper afforestation. ${ }^{64}$

\footnotetext{
61. Turkey Biological Diversity Monitoring and Evaluation Report 2012

62. National Biodiversity Strategy and Action Plan

63. Bastrup-Birk EEA's contribution to biodiversity maintenance. European Forest Week Engelberg 2015

64. National Biodiversity Strategy and Action Plan 2007.
} 
FIGURE 22 TURKEY TIMBER PRICES (\$/M³)

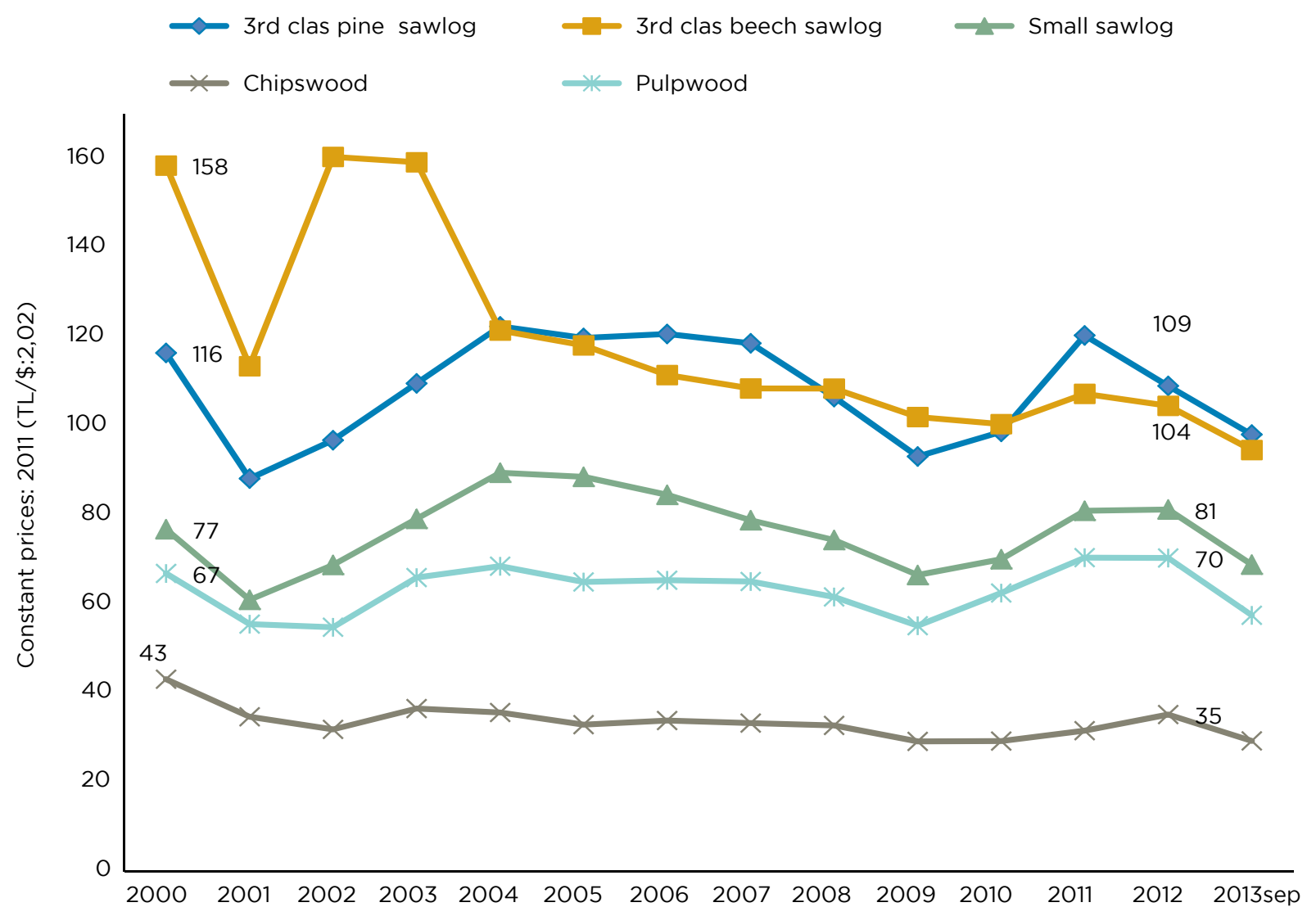

Source: Bali 2013

The Law on National Parks outlines the legal framework, defines the status and regulations for the designation and management of protected areas. There are 40 National Parks (828,614 ha), 204 Nature Parks (99,394 ha), 31 Nature Protection Areas (64,224 ha) and 112 Nature Monuments (6,993 ha). A further 1,192,794 ha is set aside in 81 wildlife conservation areas for the protection of rare and endangered species under the Hunting Law. The total land protected area was 6,782,628 ha at the end of 2015 or 8.7 percent of the land area. According to another calculation, the combined single surface area of protected areas, both land and sea, is $5,964,099$ ha or 7.65 of the country's surface area. This compares with an EU average of 18.14 percent land designated as Natura 2000 sites. $^{65}$

\subsection{Role of Private Sector Wood Industry / SMEs}

Turkey has a large wood processing sector. Primary processing (sawmills) is undertaken by an estimated 7,013 sawmills. The traditional sawnwood mills have been slow to invest and improve technology. There is however on-going rationalization within the sector with smaller mills closing. The pallet and packaging mills (estimated at 637) have invested in new technology and are considered efficient. There are around 30,000 furniture manufacturers again mainly small scale with only 150 employing more than 100 staff and only 40 with more than 250 employees. ${ }^{66}$ Total employment is estimated at 150,000. The furniture industry has seen significant growth over the past decade driven

65. Natura 2000 Nature and Biodiversity Newsletter Number 38 June 2015. European Commission. 66. USDA Foreign Agricultural Services Gain Report (2010). Forest Products Report for Turkey. 
by demand from a growing population, migration to the cities and rising incomes. The furniture sector is concentrated in Istanbul, Ankara, Izmir, Kayseri, Adana and Bursa-Inegol. Turkey imports circa 1 million $\mathrm{m}^{3}$ of sawnwood of which circa 0.9 million $\mathrm{m}^{3}$ is coniferous, Black sea countries such as Russia, Ukraine, Georgia, Romania and Bulgaria supply more than 90 percent of these imports.

Timber prices are considered by the wood industry sector to be relatively high when compared with Europe. This is due in part to the strong demand and rapid growth over the past decade but also to the relatively high cost of harvesting and inefficiencies along the various elements of the supply chain. Notwithstanding the high timber prices, in real terms prices have remained relatively flat over the past decade (Figure 22). However, if the sector is to continue to develop it will be necessary to improve its competiveness and this in part can only be achieved through more efficiencies in how timber is harvested and supplied across the sector. The GDF Strategic Plan 2013-2017 recognizes this prerequisite for future development and has set targets for reducing the ratio of production costs to timber sales revenue from 33 percent in 2013 to 21 percent by 2017 through mainly increasing the proportion of standing sales to 55 percent by 2017. This strategy assumes that the necessary supply chain infrastructure including professional harvesting contractors will more than double over a four-year period and will develop expertise using more modern equipment and yield efficiencies. In the absence of a more planned and phased approach this is unlikely to happen.

Taking the industrial wood sector overall an estimated 77 percent of domestic demand is met by sales of roundwood from GDF, 15 percent by the private sector with the balance coming from imports. ${ }^{67}$

Turkey's wood based panels sector has experienced rapid growth in recent years due to a boom in the construction industry and rising incomes. Turkey's board production was $100,000 \mathrm{~m}^{3}$ in the early 2000s, increased to 5.5 million $\mathrm{m}^{3}$ by 2010 and with additional capacity added in 2012-2014 Turkey is now in the top five panel producer worldwide. There are circa 40 facilities, 22 of which produce chip board while 18 produce fiber board. According to the Chip Board Industrialists Association (2012) chip board plants had an established capacity of

FIGURE 23 PANEL INDUSTRY PRODUCTION CAPACITY BY YEAR

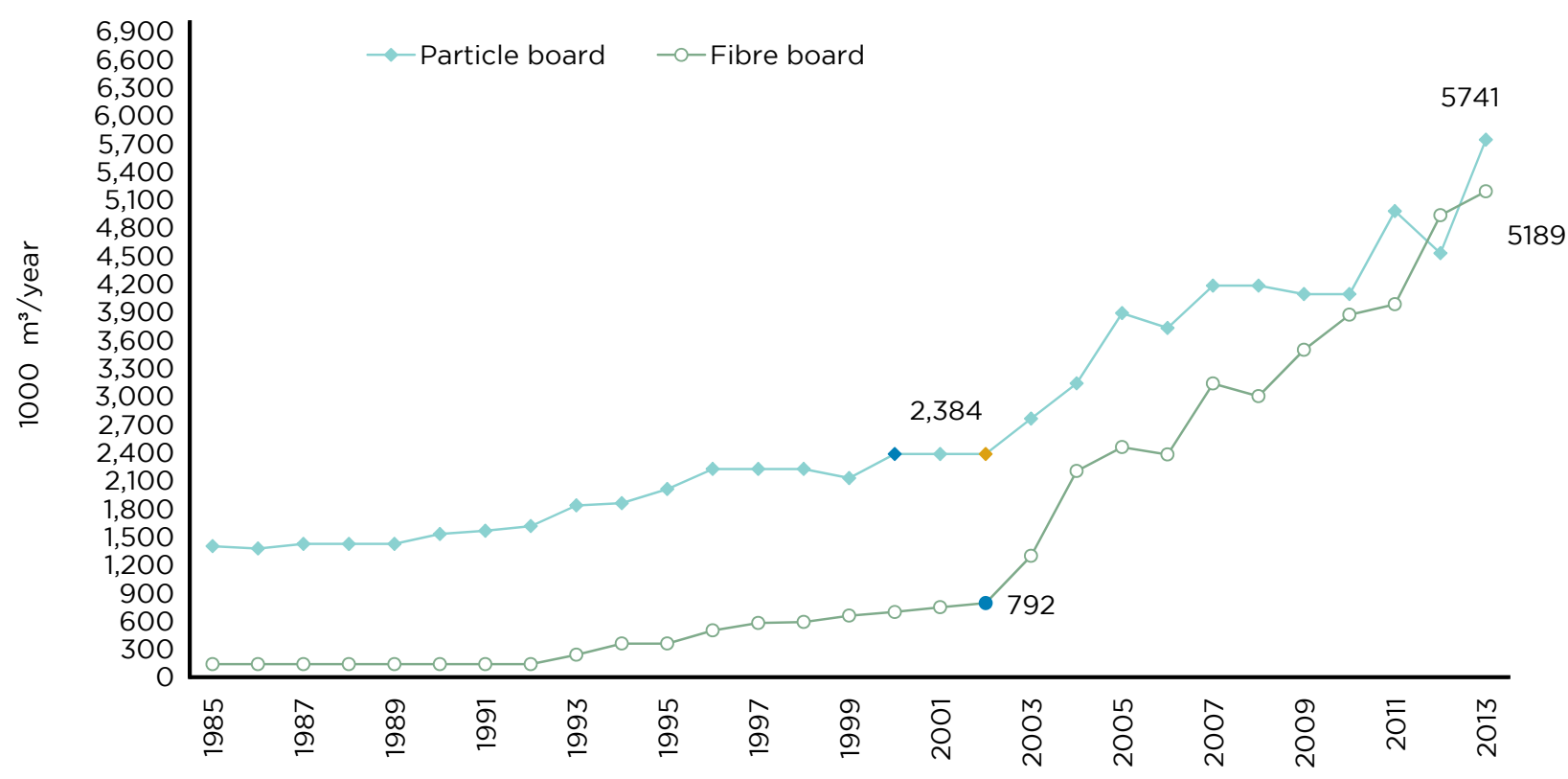

Source: Bali 2013

67. Bali, R. (2013) Market Developments in Turkey. Metsa2013 Joint session of ECE committee on forests and forest industry. 
$17,427 \mathrm{~m}^{3} /$ day and an actual daily production of $14,437 \mathrm{~m}^{3}$ /day $\left(5,269,505 \mathrm{~m}^{3}\right.$ per year) while the capacity of established and active fiberboard mills was 13,645 $\mathrm{m}^{3} /$ day $\left(4,980,425 \mathrm{~m}^{3} /\right.$ year $)$. Due to expansion this increased further in 20122014 (Figure 23). The yearly wood requirement for active capacities (as opposed to that of the established capacities) is 10.4 million $\mathrm{m}^{3}$ of wood for chip board. Likewise, wood needed for fiber board is 15 million $\mathrm{m}^{3}{ }^{68}$ The shortfall in raw material, mainly for the medium density fiberboard (MDF) panels, is met through imports and in 2013 Turkey imported 3.28 million $\mathrm{m}^{3}$ of chips principally from the USA and Canada and was the second largest chip importer in Europe. ${ }^{69}$ Security of raw material supply is an issue going forward but despite this there are plans for further expansion.

Taking the wood processing sector overall and at current harvesting levels, an estimated 64 percent of domestic demand is met by sales of roundwood from GDF, 17 percent by the private sector with the balance of 17 percent coming from imports.

\subsection{Public Involvement and Participation}

The best public participatory management is based on mutual trust, enhanced communication and co-operation among all stakeholders involved in process. This may contribute to sustainable forest management by; increasing public awareness among the public, maximizing the total benefits of forests, ensuring the sharing of costs and benefits in an equitable way and, enhancing the social acceptance of sustainable forest management. ${ }^{70}$

Various provisions of the Forest Law envisage some benefits for rural populations living in or near forests without aiming at an effective involvement of the public in decision making. Nonetheless, in recent years, some private actors, such as forest village cooperatives, forestry industry and non-governmental organizations, have become progressively involved in the forest sector and have a significant role in major forest management activities. $^{71}$

Unfortunately, the forestry legislation makes no specific reference to a right of access to information and decision making processes of the interested stakeholders other than the state forest service and related public institutions.

The mandate of the GDF to achieve enhanced public involvement and participation in sustainable management of forest resources can only be achieved through the introduction of innovative arrangements for exchanging information, consultation, cooperation and participation in forestry activities, with external groups and organizations especially NGOs, and the general public.

\subsection{Forest Certification, FOREST EUROPE and Impact of the EU Timber Regulation and the US Lacey Act}

\subsubsection{Forest Certification}

Forest certification provides an independent assurance that the quality of management practiced by an enterprise conforms to specified standards. In the case of forests, the management of the forest is compared to a standard of good forestry practice. There are a number of forest certification schemes worldwide, but in Europe the two most active schemes are the Forest Stewardship Council (FSC) and the Program for the Endorsement of Forest Certification Schemes (PEFC).

The main state-owned forest enterprises in Europe have become certified for a combination of reasons, not least being the recognition that markets for timber and timber related products are increasingly demanding that products are

68. Yıldırım et al (2014) Wood-based panels industry in Turkey: Future raw material challenge and suggestions. Maderas. Ciencia y tecnología 16(2): 175-186, 2014.

69. Forest products annual market review 2013-2014. UNECE

70. The Ministerial Conference for Protection of Forests in Europe (MCPFE), 2002.

71. Workshop for the Review and Validation of the Draft Study on Forestry Legislation of FAO SEC countries, Istanbul, $16-18$ July 2012. 
TABLE 27 FOREST AREA CERTIFIED

\begin{tabular}{|c|c|c|c|c|c|c|c|}
\hline \multirow[b]{2}{*}{ Indicator } & \multirow[b]{2}{*}{2011} & \multirow[b]{2}{*}{2012} & \multirow[b]{2}{*}{2013} & \multirow[b]{2}{*}{2014} & \multicolumn{2}{|c|}{ Planned } & \\
\hline & & & & & 2015 & 2016 & 2017 \\
\hline Certified Forest ('OOO ha) & 93 & 1,425 & 1,796 & 2,367 & 3,250 & 3,600 & 4,000 \\
\hline
\end{tabular}

Note: Definition for forest has impact on area classed as certified

certified. Secondly, certification demonstrates to the public, to the forest sector stakeholders and to the environmental community that forests are being responsibly managed. It also provides greater transparency as to how forest resources are managed and an opportunity for stakeholders to engage with forest owners including the state.

The GDF has elaborated sustainable forest management (SFM) National Criteria and Indicators comprising 6 criteria and 28 indicators and their use and understanding has been supported through an extensive series of workshops countrywide. These are based on FOREST EUROPE criteria with adaptation of the indicators to suit the Turkish situation.

The process of state forests becoming certified began in 2010 with a pilot project in Bolu. By the end of 2014 a total area of 2.4 million ha has been certified to Forest Stewardship Council (FSC) (Table 27). The certified forest area produces circa 3.5 million $\mathrm{m}^{3}$ annually. The GDF plans to expand the area under certification to $5,000,000$ ha by the end of 2019 .

There is no national Turkey forest standard for either FSC or PEFC and the forests were certified under either the generic Woodmark standard of the Soil Association or Qualifor standard of Société Générale de Surveillance (SGS). The GDF is collaborating with the Turkish national standard authority towards the development of a PEFC standard for Turkey.

The forest products sector has made significant progress in terms of the trade in imports and exports of wood and wood based products. Concurrent with this market development, the market for certified forest products (CFPs) has begun to emerge. The demand for CFPs has come mainly from export markets. However, it has also been assisted by the fact that most of the forest products imported especially from European countries are already certified. The first chain of custody (COC) certificate was issued in 2008 and as of the end of 2014 there were 257 valid CoC certificates under FSC. A recent survey showed that the majority of companies within the sector were aware of certification and believed it would have positive impact on sales although this varied with particular market segment being lowest in the solid wood products sector and highest in wood panels and paper manufacturers. ${ }^{72}$

\subsubsection{FOREST EUROPE}

FOREST EUROPE is the Pan-European policy process for the sustainable management of the continent's forests founded in 1990. It develops common strategies for its 46 participating countries and the European Union (EU) on how to protect and sustainably manage forests.

Since its foundation, twenty-one resolutions have been adopted at seven Ministerial Conferences ${ }^{73}$ (Strasbourg 1990, Helsinki 1993, Lisbon 1998, Vienna 2003, Warsaw 2007, Oslo 2011 and Madrid 2015). Through these commitments, the concept of sustainable forest management (SFM) has been defined and continuously developed at the PanEuropean level.

Turkey has been a member of FOREST EUROPE since its inception and is currently a member of the General Coordinating Committee (GCC coordinates the FOREST EUROPE work and advises the Liaison Unit on implementation of FOREST EUROPE decisions and on strategic developments).

\footnotetext{
72. Ahmet Tolunay, A and Türkoğlu T. Perspectives and Attitudes of Forest Products Industry Companies on the Chain of Custody Certification: A Case Study from Turkey. Sustainability 2014, 6, 857-871.

73. http://www.foresteurope.org/ministerial_conferences
} 


\section{FIGURE 24 FOREST EUROPE RESOLUTIONS}

\begin{tabular}{|c|c|c|}
\hline ECOLOGICAL & ECONOMIC & SOCIO-CULTURAL \\
\hline \multicolumn{3}{|c|}{ W1 Forests, Wood and Energy } \\
\hline \multicolumn{3}{|c|}{ W2 Forests and Water } \\
\hline \multicolumn{3}{|c|}{ V1 Cross-sectoral Cooperation and National Forest Programmes } \\
\hline V4 Forests Biological Diversity & V2 Economic Viability of SFM & \multirow{2}{*}{$\begin{array}{l}\text { V3 Social \& Cultural } \\
\text { Dimensions of SFM }\end{array}$} \\
\hline \multicolumn{2}{|c|}{ V5 Climate Change and SFM } & \\
\hline & \multicolumn{2}{|c|}{ L1 Socio Economic Aspects of SFM } \\
\hline \multicolumn{3}{|c|}{ L2 Pan European Criteria, Indicators and PEOLG for SFM } \\
\hline \multicolumn{3}{|c|}{ H1 Sustainable Management of Forests in Europe } \\
\hline \multicolumn{3}{|l|}{$\mathrm{H} 2$ Conservation of Biodiversity } \\
\hline \multicolumn{3}{|c|}{ H3 Cooperation with Countries in Transition } \\
\hline \multicolumn{2}{|c|}{ H4 Adaption of Forest to Climate Change } & \\
\hline S1 Monitoring of Ecosystems & & \\
\hline S2 Genetic Resources & & \\
\hline \multicolumn{2}{|c|}{ S3 Data Bank on Forest Fires } & \\
\hline \multicolumn{2}{|c|}{ S4 Adapting the Management of Mountain Forests } & \\
\hline S5 Research Tree Physiology & & \\
\hline S6 Research Forest Ecosystems & & \\
\hline \multicolumn{3}{|c|}{ M1 Forest Sector in Green Economy } \\
\hline M2 $\mathrm{Pr}$ & ecting Forests in Changing Envir & ent \\
\hline
\end{tabular}


In addition to quantitative Criteria and Indicators, qualitative indicators have been elaborated and endorsed at the Pan-European level to address forest policies, institutions and instruments for SFM in general, as well as more specific policy areas. The assessment of these indicators helps monitor the status and changes in policies, institutions and instruments, enhance accountability and transparency of policy making, and allow a better understanding of the interplay between the state of forest and policy making. They also support the strategic orientation of policies and, over time, help create more efficient and effective policies and institutional arrangements to govern SFM.

\subsubsection{Rovaniemi Action Plan}

The Rovaniemi Action Plan for the Forest Sector in a Green Economy, adopted in 2013, describes how the forest sector in the United Nations Economic Commission for Europe (UNECE) region could lead the way towards the emerging green economy at the global level. It provides an overall vision, objectives and specific activities, and identifies potential actors, who might contribute to achieving the stated objectives. It is not a binding plan, nor does it contain prescriptive recommendations to Governments, international organizations or stakeholders, who are free to adopt, adapt, in full or in part, or not to implement the Action Plan as they wish. The implementation of the Action Plan is being monitored by the UNECE/FAO Forestry and Timber Section which will also explore ways and means to measure the contribution and the progress of the forest sector towards a Green Economy.

The first draft of the National Action Plan for Forest Sector in a Green Economy was prepared by the MFWA in 2014 with the GDF as the overall coordinator. The plan includes targets for each of the five pillars ((1) Sustainable production and consumption of forest products; (2) A lowcarbon forest sector; (3) Decent green jobs in the forest sector; (4) Long term provision of Forest Ecosystem Services; and (5) Policy development and monitoring of the forest sector in relation to a green economy) and identifies the body (department / general directorate) responsible.

\subsubsection{EU Timber Regulation and US Lacey Act}

EU Regulation 995/2010 also known as the (Illegal) Timber Regulation counters the trade in illegally harvested timber and timber products through three key obligations: (1) It prohibits the placing on the EU market for the first time of illegally harvested timber and products derived from such timber; (2) It requires EU traders who place timber products on the EU market for the first time to exercise 'due diligence'; and (3) It requires EU traders to keep records of their suppliers and customers (traceability). The Regulation covers a wide range of timber products and came into force on 3rd March 2013.

It is also worth noting that in 2008 the USA amended the 100-year old Lacey Act to include the banning of commerce in illegally sourced plants and their products, which includes logs, sawn wood, furniture, pulp and paper. This means that all wood products must be harvested, transported, processed and exported in accordance with the relevant local legislation. The Lacey Act is a factbased rather than document based statute in that no document is a 100 percent guarantee of legality. It is up to the US importers and traders to exercise 'due care', to ensure that all imports are produced in accordance with all relevant legislation.

Transparency International corruption perception index (CPI) saw Turkey's score decrease from 50 to 45 in $2014 .{ }^{74}$ Although based on perceptions only, the $\mathrm{CPI}$ is widely regarded as a key indicator of the level of corruption in a country. It is an integral part of the FSC Controlled Wood (CW) system, and is often used in due diligence systems for legal timber sourcing. In the FSC CW system, a CPI below 50 places a country in the "unspecified risk" category for legal timber harvesting (indicator 1.4 in the Controlled Wood category 1 - Illegally Harvested Wood). Field verification of legal harvesting is therefore required for companies sourcing $\mathrm{CW}$ from such countries. 


\subsection{Forests and Integrated Water Basin Management (multi-sectoral approach)}

Turkey is also a mountainous country that exhibits great diversity in geographical structure, topography, climate and plant cover. It is divided into 26 hydrological watersheds in terms of the overall topography. Mean annual water flow of these watersheds is circa 186 billion cubic meters. The average rainfall is about $650 \mathrm{~mm}$, but ranges from $250 \mathrm{~mm}$ to $2,500 \mathrm{~mm}$ depending on locality. As a result of the combined effects of the harsh topographical conditions and inappropriate land use practices, over 80 percent of the country soils suffer from moderate to severe erosion.

Forest management is an essential component of integrated land management. An Integrated Landscape Management (LM) approach was also suggested by the National Forestry Program (NFP) as a key target to be achieved in the medium to long term.

Two World Bank co-financed (together with national budget) watershed rehabilitation projects and an FAO technical co-operation project (TCP) have been implemented so that Turkey has already gained broad experience in watershed management practices. The Eastern Anatolia Watershed Rehabilitation project was implemented in 11 provinces (in 66 catchments) over a ten-year period (1993-2003). The Anatolia Watershed Rehabilitation project was implemented in 6 provinces. The project outcomes included the rehabilitation of degraded natural resources, particularly degraded forests and pastures in uplands, soil protection and erosion control in mountainous micro catchments as well improvement of the livelihood of rural communities, introducing of innovative income generating interventions.

As a response to the global initiatives particularly to the mandate of Chapter 13 of Agenda 21, a twoyear project, "Development of public participation and improvement of socio- economic prosperity in mountain communities; Yuntdagi Model" (TCP/ TUR/3102) was implemented through active participation of a great number of stakeholders including rural people and NGOs over the period 2008-2010. The objectives of the project were; to contribute to implement sustainable mountain development in Turkey, to improve the livelihoods of rural mountain people through the establishment of viable and area-specific income-generating activities.

The Japan International Cooperation Agency (JICA) co-funded (together with national budget) Coruh River Watershed Rehabilitation project (2012-2019) is addressing the integrated watershed rehabilitation including vegetation, soil and water resources, enhancing the living standards of rural populations, protection of the soil, rehabilitation of degraded forests, prevention of natural disasters and other rehabilitation and prevention activities in the selected 13 micro catchments. GDF is the coordinating agency of the project.

The International Fund for Agricultural Development (IFAD) co-funded (together with national budget) Murat River Watershed Rehabilitation project (20132019) has three components; (a) natural resources and environmental management, (b) investments in natural resources and environmental assets and (c) investments in small-scale agriculture. GDF is the coordinating agency of the project

\subsection{Fiscal Issues (financing forest management)}

The GDF, established by Law Nr. 3234 for the protection, development and sustainable management of the country's forests, is a public organization having legal personality. In order to fulfil its mandate, the GDF has two different budgets i.e. a special budget and a revolving budget.

The general expectation from Treasury is that the activities of the GDF would be self-financing. However, the funding of expenses for afforestation, erosion control, fire control, prevention and extinguishing, soil protection and cadastral works is covered from a special budget. In accordance with the Turkish public budgeting system, when public institutions with a special budget, like the GDF, encounter a budget deficit, the Treasury contributes to those institutions to make up the 
TABLE 28 REVENUES AND COSTS GDF ('000 US\$)

\begin{tabular}{|c|c|c|c|c|c|c|c|}
\hline & & & 2012 & 2013 & 2014 & 2015 & $\begin{array}{r}2016 \\
\text { (targets) }\end{array}$ \\
\hline \multirow{7}{*}{ 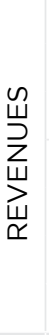 } & \multirow{3}{*}{$\begin{array}{l}\text { SPECIAL BUDGET } \\
\text { (government } \\
\text { budget) }\end{array}$} & 1-Treasury's contribution & 386,072 & 436,489 & 502,466 & 494,222 & 652,318 \\
\hline & & 2-Own revenues & 277,402 & 336,777 & 251,600 & 518,346 & 407,000 \\
\hline & & Subtotal & 663,474 & 773,265 & 754,066 & $1,012,568$ & $1,059,318$ \\
\hline & \multirow{3}{*}{$\begin{array}{l}\text { REVOLVING } \\
\text { BUDGET }\end{array}$} & 1-Wood selling revenue & 730,371 & 776,630 & 806,970 & 992,455 & $1,016,760$ \\
\hline & & 2-Other revenues & 83,629 & 81,400 & 79,180 & 46,082 & 49,950 \\
\hline & & Subtotal & 814,000 & 858,030 & 886,150 & $1,038,537$ & $1,066,710$ \\
\hline & TOTAL REVENUES & & $1,477,474$ & $1,631,295$ & $1,640,216$ & $2,051,105$ & $2,126,028$ \\
\hline \multirow{12}{*}{$\begin{array}{l}\tilde{\bullet} \\
\tilde{\bullet} \\
0 \\
u\end{array}$} & \multirow{8}{*}{$\begin{array}{l}\text { SPECIAL BUDGET } \\
\text { (government } \\
\text { budget) }\end{array}$} & 1-Personel expenses & 328,840 & 348,901 & 383,956 & 443,130 & 474,065 \\
\hline & & 2-Social insurance & 72,529 & 77,444 & 85,440 & 97,938 & 106,593 \\
\hline & & $\begin{array}{l}\text { 3-Purchases (goods and } \\
\text { services) }\end{array}$ & 56,870 & 69,381 & 53,037 & 71,640 & 63,082 \\
\hline & & 4-Current transfers & 6,864 & 14,133 & 10,349 & 17,381 & 18,380 \\
\hline & & 5-Capital costs & 180,040 & 169,641 & 179,524 & 354,297 & 342,620 \\
\hline & & 6-Capital transfers & 694 & 11,138 & 6,946 & 8,022 & 9,196 \\
\hline & & 7-Lending & 27,040 & 44,412 & 35,184 & 39,400 & 45,381 \\
\hline & & Subtotal & 672,877 & 735,050 & 754,436 & $1,031,808$ & $1,059,317$ \\
\hline & \multirow{3}{*}{$\begin{array}{l}\text { REVOLVING } \\
\text { BUDGET }\end{array}$} & 1- Investment costs & 55,130 & 69,005 & 71,040 & 59,334 & 78,588 \\
\hline & & 2-Current expenses & 758,870 & 789,025 & 815,110 & 947,812 & 988,122 \\
\hline & & Subtotal & 814,000 & 858,030 & 886,150 & $1,007,146$ & $1,066,710$ \\
\hline & TOTAL COSTS & & $1,486,877$ & $1,593,080$ & $1,640,586$ & $2,038,954$ & $2,126,027$ \\
\hline
\end{tabular}

deficit. The recipient must provide an element of marching funds, which in the case of the GDF comes from permits for mining, tourism and recreation (Articles 16-18 of the Forest Law). The special budget requires approval by Parliament. The basis for investments under the special budget is the GDF Strategic Plan which is in line with the requirements of the 10th National Development Plan. Monies allocated under the special budget are ring fenced and cannot be used for other purposes.

The revolving budget comprises mainly revenues from roundwood sales, and is used to offset the major forest management expenses such as protection, maintenance, improvement, regeneration, rehabilitation, production works for roundwood and NWFPs. Thus the revenues coming from the forest resource are in the main returned to forests to improve, regenerate and expand forests. The revolving budget requires approval by the Minister. As of the end-2016, circa 40 percent of the revolving fund budget goes towards general administration expenses, 37 percent towards production expenses and costs and the balance of 23 percent, towards capital investments e.g. forest roads. The operation of the revolving budget is more flexible then the special budget and, depending on circumstances and the operating environment during the year, the funds and activities can be changed to reflect changing market needs and changed operating environment.

There is a well-defined budget preparation process which starts in July/August each year. The Forest Districts prepare their proposals and these are reviewed at Regional Directorate level before being submitted to the relevant units in the headquarters for further review and analysis. Following this, a draft budget is prepared and goes to the budget commission which assesses past performance and compliance with the strategic plan and objectives. A revised draft is prepared and forms the basis of discussions with the Regional Directorates and also input from GDF headquarters until a final budget is agreed. Once the budget is agreed then each Forest District finalizes their program in line with the new budget. Budgets are monitored monthly at all levels within GDF and where necessary corrective actions are taken. Both budgets operate as three year rolling budgets. 
FIGURE 25 IMPACT OF FORESTRY SECTOR ON THE REST OF THE ECONOMY

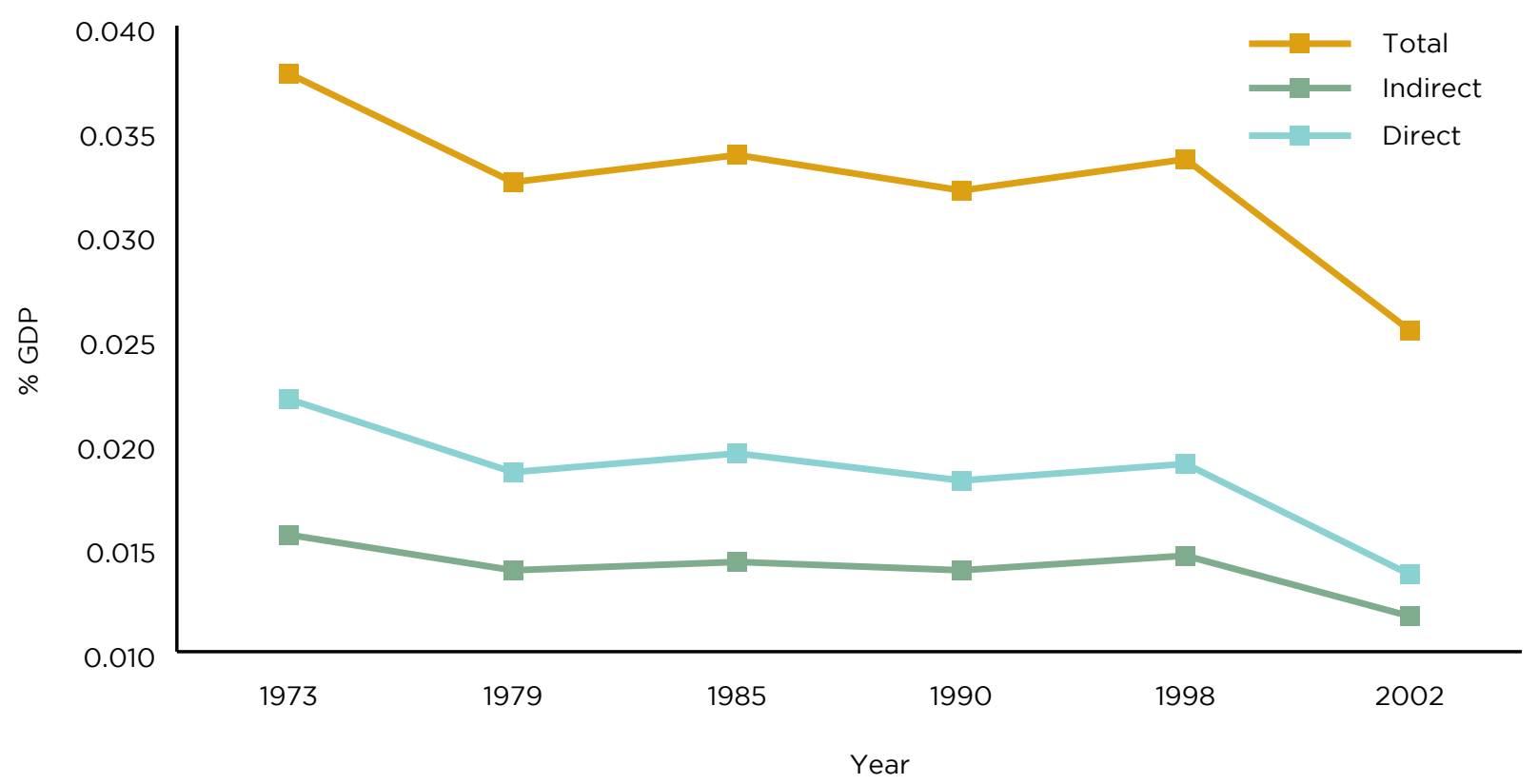

Source: Turkstat (data for 1973-2002); Analysis by World Bank (2016)

\section{TABLE 29 TOP 15 SECTORS WITH LINKAGES TO THE FORESTRY SECTOR (PERCENT)}

\begin{tabular}{|l|l|r|r|}
\hline & Product sector & Direct & Indirect \\
\hline 02 & Products of forestry, logging and related services & 65,276 & 64,605 \\
\hline 20 & $\begin{array}{l}\text { Wood and products of wood and cork (except furniture); articles of straw and } \\
\text { plaiting materials }\end{array}$ & 9,432 & 1,680 \\
\hline 21 & Pulp, paper and paper products & 3,058 & 974 \\
\hline 37 & Secondary raw materials & 1,023 \\
\hline 36 & Furniture; other manufactured goods n.e.c. & 862 & 726 \\
\hline 22 & Printed matter and recorded media & 846 \\
\hline 10 & Coal and lignite; peat & 794 \\
\hline 73 & Research and development services & 746 \\
\hline 16 & Tobacco products & 403 & 193 \\
\hline 13 & Metal ores & 367 \\
\hline 55 & Hotel and restaurant services & 333 \\
\hline 45 & Construction work & 287 & 79 \\
\hline 74 & Other business services & 90 \\
\hline 27 & Basic metals & 275 \\
\hline 26 & Other non-metallic mineral products & 231 \\
\hline
\end{tabular}


leaves the GDF overly exposed to fluctuations in the national economy and timber markets. The development of other sources of revenue based around the sustainable management of the forest resource will be necessary to provide more stable revenue flows into the future.

\subsection{Linkages of the Forestry Sector to the Rest of the Economy}

The forestry sector has important linkages to other sectors in the economy. From the first planning period around 1939, the sector has had important forward and backward linkages mainly through industrial forestry. ${ }^{75}$ Since that time - the sector has diversified and linked itself to numerous other sectors in the economy. However, the sector's growth trend has been on the decline mostly as a result of large growth in other sectors such as cement IT and manufacturing (e.g. white goods). Using input-output tables from Turkstat, it can be seen in Figure 25 that the total direct and indirect impacts of forestry activities on the rest of the economy has been declining since the early 1970's until 2002. While input-output tables from 2002 to the present are not available - this period experienced tremendous growth until around 2007 - and widely variable growth thereafter to the present - largely as a combination of political, institutional and economic reasons such as the response to the financial crisis. ${ }^{76}$
Sectors purchase forest products and use them as inputs to produce other goods. Likewise, the forestry sector buys inputs from other sectors. The economy-wide demand for forest products grows as other sectors grow - so it is important to know which sectors have the highest demand for forest products. Listed in Table 29 are the top 15 sectors in terms of how forest products are used in other sectors (see Appendix 6 for full results). The largest share is internal to the forest sector with 74 percent and 85 percent of direct and indirect benefits - then pulp and paper, raw materials (recycling), furniture, mining, construction and other specific products. Together these top 15 comprise over 94 percent of direct and indirect output.

The forestry sector is exposed to demand fluctuations in other sectors and thus needs to understand other product markets. It should also develop different options to help mitigate the impacts of variability in other product markets. One natural mechanism would be to diversify its product range to other sectors (more of them), or to those with stronger market demand (deepening). Another strategy could involve a diversified portfolio of forest products that minimize either seasonal or economic fluctuations. For example, produce a range of products that meet high-end needs during good economic times (higher valueadded products), and another range of products that could weather less favorable economic conditions (lower value-added, but higher volumebased, products).

75. Danchev, A. et al., 2005. Turkey. Acta Silva Lignaria Hungarica, Special Edition, 779-811.

76. Acemoglu and Ucer, 2015. The Ups and Downs of Turkish Growth, 2002-2015: Political Dynamics, the European Union and the Institutional Slide. NBER Working Paper 21608. 
P on

*ns $6 x^{3}+x^{2}$

w.

$\left.1 x^{2}\right)^{2}+2 x$

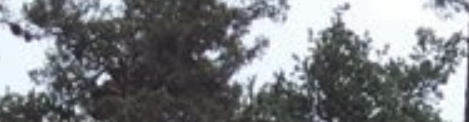

c. ser.t.

$\cos _{i \rightarrow \infty} \ln ^{4}$

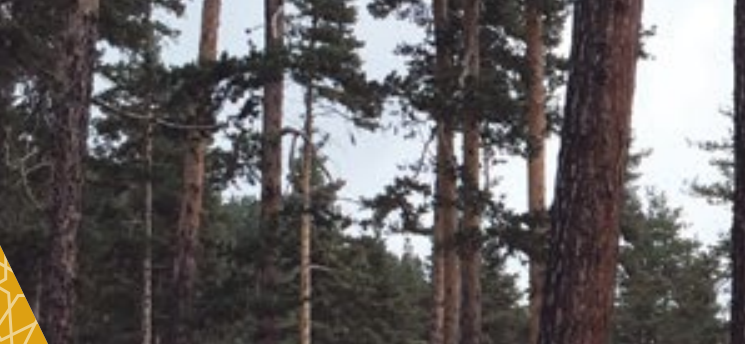

$128,4 \%$

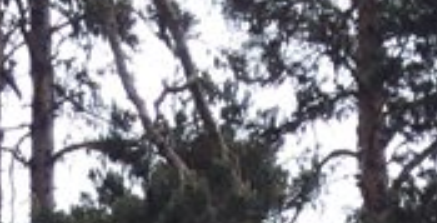

Nen of o

(4) of of

No

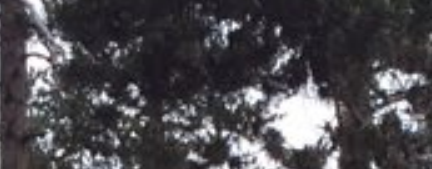

as $+4,1$

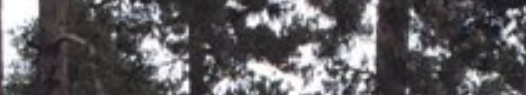

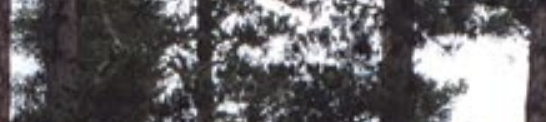

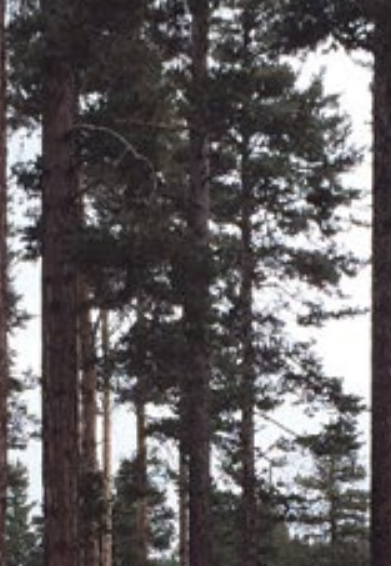
4

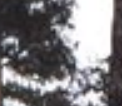

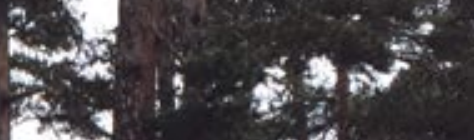

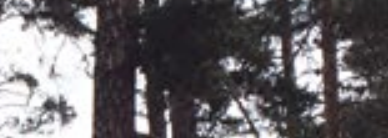

+ond

as nt

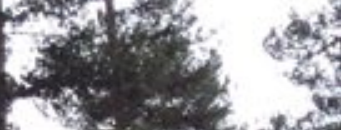
$x^{2}=-20$ $\rightarrow a^{2}-$

in 5 int

7x

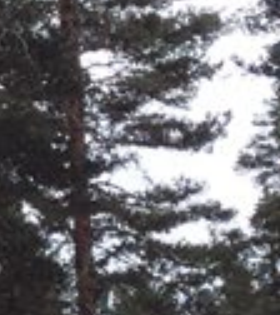

ato ory

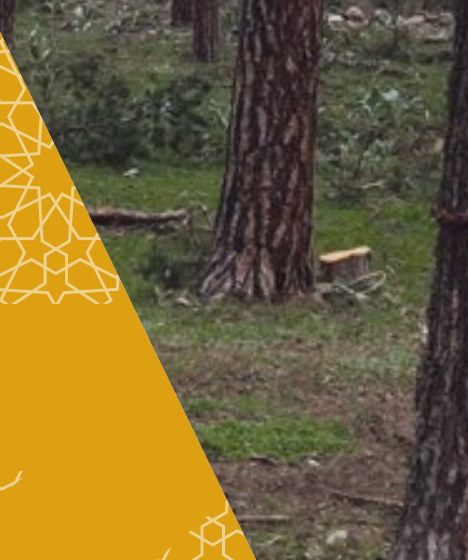

1. in $^{2}$

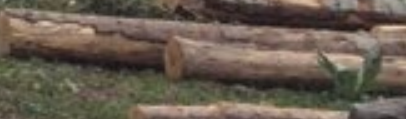

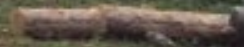

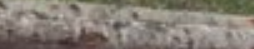




\section{CHALLENGES AND OPPORTUNITIES FOR IMPROVED SFM}

\subsection{General}

The 22.3 million ha of forest, 99.9 percent of which is owned and managed by the State, represents a valuable resource not only in terms of its impact on soil erosion, watershed management, carbon sequestration, biodiversity but also in supporting the livelihood of vulnerable forest village communities and providing the raw material supply for a world class wood panels industry and wood processing sector. To ensure that the forest resource can continue to provide these valuable functions and support both forest villages and the wood processing sector in a sustainable and cost efficient manner into the future requires that Turkey and the GDF in particular will have to address a number of challenges around the following topics:

a. Forest Resource Information;

b. Forest Legislation;

c. Improving Competitiveness;

d. Enhanced Wood Supply;

e. Sustainability of Forest Resources; and

f. Role of the State.

\subsection{Forest Resource Information}

The development of society and the increasing awareness of the need to sustainably manage the world's natural resources, including forests, and the reality of climate change, has led to the increasing need for reliable multi-resource information and reporting requirement on the status of forests under a number of international conventions. Reliable, current and consistent information is required to inform domestic forest policy, to support forest research and fulfil national and international reporting commitments. This is currently lacking as there is no National Forest Inventory.

The purpose of the National Forest Inventory (NFI) would be to record and assess the extent and nature of Turkey's forests, both public and private, in a timely, accurate and reproducible manner to enable the sustainable development of the country's forest resource. It is an essential prerequisite to the future sustainable management of forest resources. While some initial work was undertaken in 2009, the need now is for an NFI design and methodology to be finalized together with the supporting logistics e.g. recording, analysis and reporting software, training and technology. Once this is finalized the implementation of the NFI can be planned and resources allocated.

A pre-requisite to the NFI is the definition of forests which is important especially in terms of common reporting to international commitments and for comparison / benchmarking between different countries. While there are many national definitions of forest throughout Europe (Figure 26), in terms of international reporting where current FAO definitions apply, ${ }^{77}$ Turkey's definition of forest overstates the forest resource in comparison with European countries. Under the FAO definition, perhaps as much as 40 percent of Turkeys forest, mainly the degraded forests, would be classed as other wooded land i.e. land not defined as "Forest", spanning more than 0.5 hectares; with trees higher 


\section{FIGURE 26 COMPARISON OF THE DEFINITIONS OF FOREST IN EUROPE}

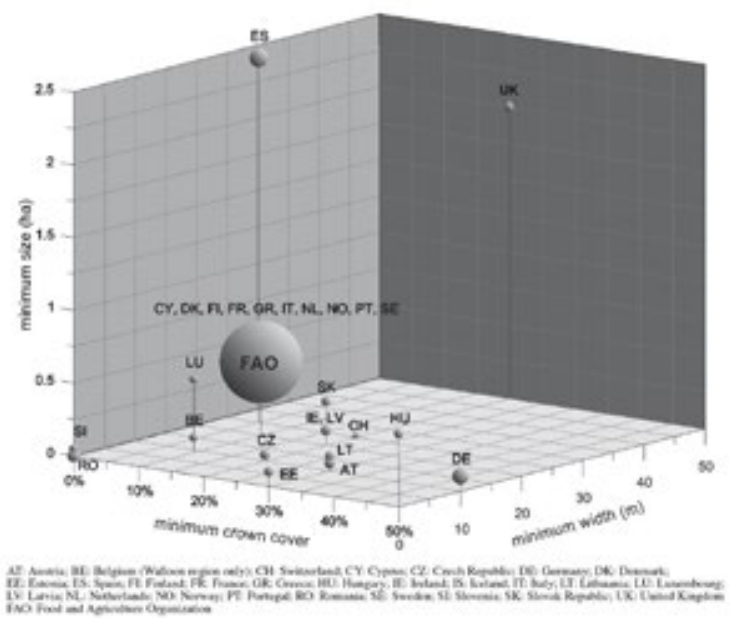

than 5 meters and a canopy cover of 5-10 percent, with some areas failing to meet this criteria and being classed as other land. However, to align Turkey with most other European countries by reducing the minimum area requirement and to include the highly productive private sector plantations (currently not excluded from the Turkish definition of forests) would result in an increase in the forest area.

The change in the definition of forest could have legal ramifications, however this could be overcome by including two categories of forest - one for farm forests with a reduced minimum area and including non-native species, and one for natural / seminatural forests.

Closely aligned with improvement in forest resource information through the roll out of a NFI is improved information on the economic contribution of the forest resource to Turkey. The pilot study in the Bolu region highlighted the importance of including values for NWFPs and forestry ecosystem services in any economic analysis of forestry contribution to the economy. The absence of aggregated data on the economic contributions related to non-wood forest products (NWFPs) and their value, and the lack of information systems that can incorporate such data systematically are major bottlenecks in a better understanding of forest sector contributions. ${ }^{78}$ They also represent a deficiency when it comes to improved management to enhance the total economic contributions of forests. Indeed, the effective absence of information on the value of such benefits from forests has meant an overemphasis in forest governance systems on managing forests for products that are highly visible, formally recognized, and with cash market value.

Better information on the extent and value of ecosystem services is required if policy and decision makers are to be properly informed when making decisions and or allocating resources within the forestry sector and to enable forest managers to enhance / maximize the economic contribution of forestry to the economy.

\subsection{Forest Legislation}

The main forest legislation was framed over half a century ago and although subject to many amendments in the intervening years suffers from a number of identified deficiencies, many of these were recognized in the NFP adopted in 2004, such as the Forest Law largely ignores the private sector, and that the draft Nature Protection Law (which is not in line with the EU acquis) that if adopted without implementing legislation, would repeal the National Parks Law, causing a legal vacuum.

There is now an opportunity to redraft the main Forest Code and in so doing to (a) redress the identified deficiencies, (b) support the competitiveness of the sector through changes in methods for timber sales, and (c) take on board the lessons learned from other countries who have redrafted their forest legislation over the past two decades which include:

a. Avoid legislative over-reaching;

b. Use clear and concise legislative drafting style;

c. Avoid unnecessary, superfluous or cumbersome licensing and approval requirements / procedures;

d. Include provisions that enhance the transparency and accountability of forest decision-making process; and

e. Use a participatory process in drafting the Law.

78. Background Paper 1 Economic Contributions of Forests.(Agrawal et al)., Background paper prepared for the United Nations Forum on Forests 20 March, 2013, Istanbul, Turkey. 
The recent FAO report on forest legislation ${ }^{79}$ notes that identifying lands to be made perpetually subject to the forestry regime by law may be very difficult, as the evolution of society inevitably brings about needs for other (possibly conflicting) land uses. It is important to have an effective, participatory land use planning process in place in order to facilitate consensus among concerned sectors of society. The contents of forestry legislation should be in line with such a process. Participation in this context requires a true commitment to listen and understand the needs, objectives and capacities of the intended users of the law and the forest resource and to finding ways to accommodate the multiple interests at stake.

One way to promote greater transparency while at the same time to involve stakeholders would be to establish a forest advisory body representative of the sector as a permanent officially recognized forum for discussion.

The drafting of new legislation would provide the opportunity to fully incorporate the principles of SFM and for integrated management planning covering not only forest produce yield but also whole ecosystems, social aspects, environmental and biodiversity values, impacts on climate change and risks of desertification. The new law would facilitate the inclusion of new definitions of forest to harmonize with international reporting requirements and to include other useful categories such as farm forests and semi-natural forests.

NWFPs and their sustainable exploitation, including adding value domestically, represent a significant opportunity to enhance the livelihood of forest villagers and the wider rural communities. The drafting of new legislation would also allow for the incorporation of usufruct rights for forest villages for NWFPs and for their sustainable management. Such rights and provisions for sustainable management would facilitate the development of NWFPs.

\subsection{Improving Competitiveness}

Timber and timber products are globally traded commodities. If the wood processing sector in Turkey is to remain competitive and compete with imports, then the GDF, which will remain the dominant supplier of roundwood into the foreseeable future, has an important and strategic role to play. The challenge for the GDF is to how mobilize its annual timber harvest in a cost-efficient and sustainable fashion, thereby facilitating the development of a competitive domestic timber processing sector through reducing costs and reconfiguring the timber supply chain. Any new supply and procurement chain structures should

a. Minimize harvesting and haulage inefficiencies;

b. Allow for the presentation of contracted harvesting work packages in a more logistically efficient manner;

c. Allocate the timber resource to the processing sector as efficiently as possible while optimizing its inherent / potential value;

d. Optimize the benefits of Information Technology systems applicable to the timber industry;

e. Minimize the requirement for and / or incidence of process duplication; and

f. Maintain competition within all sectors involved.

An analysis of the component processes of the timber supply chain is required to provide an upto-date overview of the current industry cost of timber supply and procurement while identifying a range of efficiency issues relating to the current configuration of the supply chain and the resultant interaction of supplier (principally GDF), purchaser and harvesting entities including villages and cooperatives. Continued reliance on forest villages for harvesting services is potentially non-viable in the medium to long term in view of their aging and declining population.

79. Cirelli, M.T. (2013) Forestry Legislation in Azerbaijan, Central Asian Countries and Turkey - Common issues and guidelines for reform. FAO, Rome. 
This analysis would explore as part of its remit the possibility of changing the main timber sales methods and the timing and frequency of timber sales. One possibility could be the extension of standing sales from the current level of 30 percent as envisaged in the Strategic Plan 2013-2017. However, this only makes sense if the contracting infrastructure resource is incentivized to expand and become more efficient than current practices and thereby reduce costs. Another possibility is the introduction of a concession ${ }^{80}$ system for part of the timber sales volume. Concessions could form important instruments of the national forest policy and should be consistent with the broad national goals of sustainability, building on obtaining the best mix of economic, social and environmental benefits from the forests, and contributing to the restoration of degraded forests.

The GDF is a large centrally controlled organization that essentially sets its own targets, monitors itself in terms of performance, audits itself through an internal audit and reports on itself to Government and the public. It does not benchmark or compare itself against other state forest organizations. Competitiveness in any organization is underpinned by having in place best practice, processes and procedures. While the restructuring of the supply chain will bring improvements to the competitiveness of the wood industry, the GDF itself will need to provide a more efficient and quality service to the forest sector as a whole. As a first step in this process the GDF should benchmark itself against similar state forest organizations across a range of parameters including (a) financial, (b) environmental and (c) social. This analysis will provide insights as to where identifiable improvements can be made and lead to focused business process review of these aspects of how it does business.

\subsection{Enhanced Wood Supply}

There are two aspects to enhancing the wood supply form state forests i.e. short to medium term and long term. In the short to medium term the challenge for GDF is to leverage more volume from the existing forest resource in a sustainable and cost efficient manner, building on improvements in the overall model of the supply chain. Increased volumes would help replace imported material for the wood panels sector and also provide much needed security of supply so necessary for confidence and investment in the sector and in wood energy. The current levels of harvest are significantly below the annual allowable cut (AAC) and to increase will require a combination of enhanced forest resource information, investment in forest roads and development of the necessary expansion in the harvesting infrastructure. A planned and phased approach in partnership with the wood industry is required. The increased investment in forest roads could also serve as an opportunity to define best practice in forest road construction incorporating environmental guidelines and / or EIA.

In the longer term, additional volume can only be sourced through an expansion of the forest resource with a focus on fast growing industrial plantations with species like Brutia pine and Maritime pine. The GDF action plan for these two species foresees the establishment of 140,000 ha of Brutia pine and 20,000 ha of Maritime pine over the next twenty years or a rate of 8,000 ha per year. The potential area available which meets the requirements for industrial plantations in terms of productivity, slope etc. is estimated as being of the order of 1 million ha and this reduces to an estimated 400,000 ha suitable for using current machine technology. There is a shortfall between what is available and what is planned to be planted by the GDF of the order of 240,000 ha. The challenge therefore is how to increase the scale of planting through involving the private sector and thereby not only enhancing future wood supply but also facilitating the development of the private forest sector. Private afforestation refers to any plantation established by private persons and/ or legal entities on private land, degraded forest land or treasury land. Thus private forests can be on private land or state owned land. The current scheme of incentives has not resulted in levels of planting that match the requirements for industrial plantations and will need to be re-examined.

80. Concessions are a form of contract that identifies specific rights, responsibilities and obligations for both the owner of the land (the State) and the concessionaire in regards to forest planning, harvesting, road building, silviculture, and protection. 


\subsection{Sustainability of Forest Resources}

Forest resources worldwide and in Turkey are under continued threat from forest pests and diseases, fire, land use change and degradation and over exploitation. The most significant threat however is that of climate change. The impact of climate change, which will have a clear latitudinal effect. Species at the lower altitudes of mountains in Europe are already suffering from decreased precipitation and increased temperature. ${ }^{81}$ Thus, the immediate effect that climate change signals is the shift in the range of suitability for forest tree species across Europe. These changes will lead to an increase of biotic damages, as tree species become increasingly susceptible to attack from pests. Forests will also become more susceptible to abiotic damages from more frequent windstorms, droughts and forest fires.

Measures in place like afforestation and rehabilitation of degraded forests and enhanced fire warning systems are already making an impact. In the medium term however it will be important for Turkey to fully address the potential impacts of climate change in future afforestation and forest rehabilitation works through the planting or more drought resistant species and the undertaking of studies to more fully understand the impacts at an ecosystem level so that mitigating measures can be developed and put in place thereby ensuring the ongoing provision of the complete range of environmental services from forests.

Sustainability of forest resources is linked with the maintenance and sustainability of biodiversity. The challenge for Turkey is firstly how to protect and ensure the sustainability of its unique and rich biodiversity against a scenario of increasing forest utilization and societal expectations on what services forests should provide e.g. leisure, recreation and secondly how to ensure that international commitments, notably the Aichi targets, are met, that all forest ecosystem types are properly covered in protected area networks, There is the potential to improve forest biodiversity, by expanding protected areas, where necessary, and by expanding the use of integrated management in forests outside protected areas. The NFI will help in the monitoring and reporting of biodiversity within forests.

The FAO defines NWFPs as being "goods of biological origin other than wood derived from forests, other wooded land and trees outside forests". NWFPs have attracted considerable global interest in recent years due to the increasing recognition of their contribution to environmental objectives, including the conservation of biological diversity and as a source of income for rural dwellers. There is general agreement in Turkey that the area of NWFPs is underdeveloped but has significant potential as a source of local employment and export to European countries. The challenge is therefore how to sustainably exploit this valuable resource for the benefit of rural dwellers and society as a whole.

The first steps to ensure the sustainable development of the NWFPs are to (a) identify the resource and its status, (b) identify those NWFPs that offer the best opportunity for harvesting, processing, marketing and export and (c) amend the forest law to transfer user rights to forest villages and incorporate provisions for sustainable management. This should be undertaken alongside the development of codes of practice for harvesting of NWFPs to avoid over-exploitation, incorrect timing, poor storage etc. This includes the provision of technical advice on the processing and marketing of NWFPs and increased investment/provision of finance for added value would provide the basis for future development. This is of strategic importance to the long term well-being of forest villages as an income alternative for their aging population.

Cultivation might be an option for some products and could increase the total production and relieve the pressure on the wild material. Irrespective of the source, sustainable management of the resource along agreed guidelines and provision of additional investment funding will be necessary. 
The survival and well-being of forest villages is inextricably linked with the sustainability of forest resources owing to their dependence on forests to provide grazing, fuelwood, employment and NWFPs. Forest villages are experiencing outmigration and are now home to an aging and declining population. The challenge into the future is how the forest can support the livelihood and well-being of forest villages. The current model of villagers undertaking the majority of harvesting and forest works is unsustainable in the medium to long term. Alternatives recognizing the limitations of an aging population will need to be developed. Any new model will need to focus on alternative income opportunities and a changed role for villagers in relation to the forest resource. This new model could increase the focus on the harvesting and processing of NWFPs while engaging villagers in a more collaborative approach to forest management at a local level where their role would not merely be suppliers of labor for harvesting and planting but also as caretakers and protectors of the forest, a role less dependent on physical attributes but more on local knowledge and culture. This changed role would have benefits for the sustainability of forest resources while also benefitting rural populations. Some of these supporting actions already appear in GDF's Strategic Plan (2013-2017) - but will take time to implement. The new strategy could look into ways of accelerating this process.

\subsection{Role of GDF}

The GDF is a large organization covering all of Turkey. It has changed parent Ministries and undergone some internal changes in recent years. The challenge for the organization into the future is to match its role and how it does business with a rapidly changing operating environment and increasing public scrutiny.

Organizations operate in at least three different types of environment. The first consists of the historical developments bringing changes over time. It is key in helping to understand / explain an organization's strategy, structure, culture, politics and leadership style. The second is the external environment which includes socio-economic factors, the general economy of the country, political and legal influences. The third is the internal environment (Figure 27) where there are typically two sub-systems. The first is the formal which can be described as the "official" way the organization functions. The second is the informal sub-system which can best be defined as "the way we do business around here". This reflects the culture, the local and organizational politics, and the style of leadership and the motivation of staff. The key task for any organization including GDF is to manage these environments. Simply changing the organizational structure will not necessarily improve efficiency of operations or the quality of the service(s) being provided if the sub-culture is opposed to change or to implement new operating procedures.

As a first step in assessing how the organization fits with its current operating environment and what changes are required as to how it might fit into the future, given the planned changes in the forest sector and broader operating environment, the GDF should undertake an initial business process review at a high level. The initial diagnosis is both crucial and necessary. This together with the benchmarking and re-configuration of the supply chain will provide direction for future change and the delivery of improved services.

Elements identified as being part of best practice successful institutional reforms in forest sector include:

1. Remove direct links (administrative, financial) between entities responsible for public functions and state forest management in order to:

a. Eliminate potential conflicts of interest; and

b. Ensure independence, transparency and neutrality of public forest administration.

2. Increase productivity and efficiency through:

a. Establishing an independent budget for the entity managing state forests with well-defined obligations towards state budget; and

b. Development of salary schemes which are based on staff performance to reduce incentive for corruption. 


\section{FIGURE 27 ORGANISATION OPERATING ENVIRONMENT}

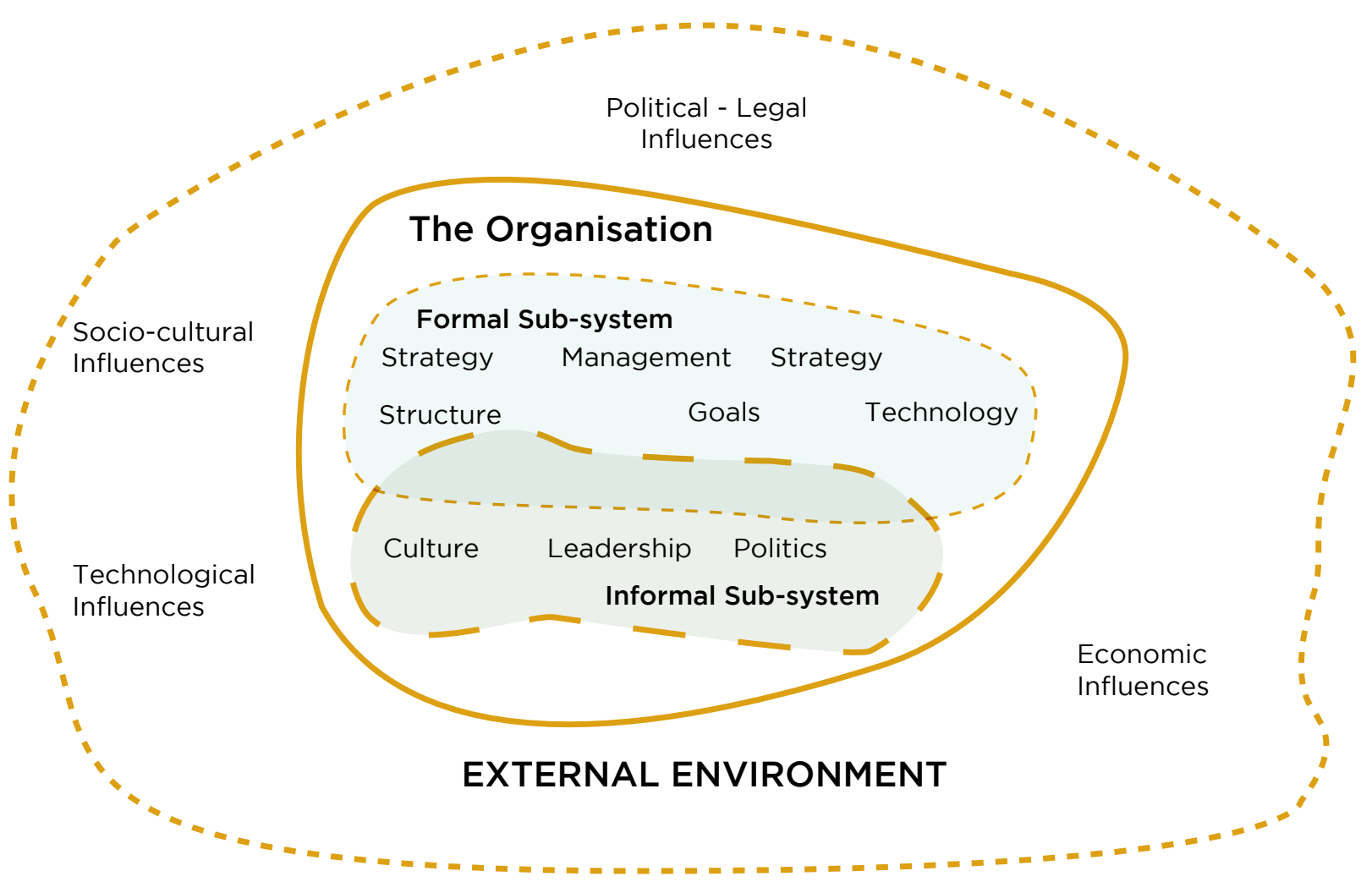

3. Ensure effective operational control over the State Forest Enterprise:

a. Require transparent budget procedures and accounting systems matching corporate standards:

b. Assign responsibility for controlling forest harvesting and management to state forest administration; and

c. Arrange financial auditing through accredited third party auditors.
4. Ensure strategic control over state forest management:

a. Establish a management board to supervise the activities of the entity managing state forests, including representatives from government, as well as professionals with qualifications in forestry, environmental conservation and corporate management. 


\section{I}

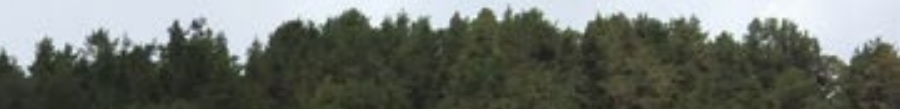

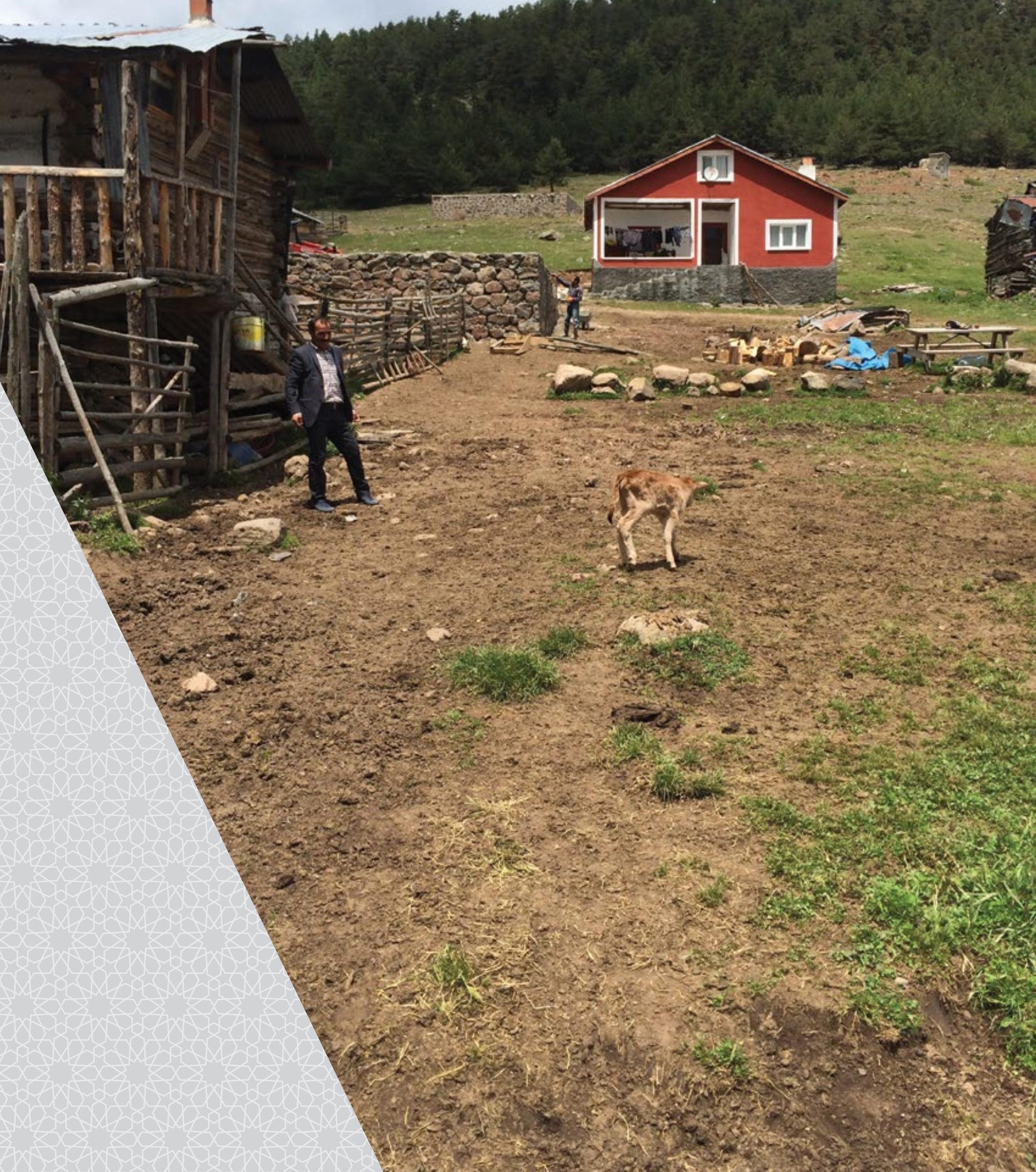




\section{APPENDIX 1: INTERNATIONAL CONVENTIONS, AGREEMENTS AND INITIATIVES RELEVANT TO FORESTS}

UNFCCC: The overriding goal of the Convention is to stabilise greenhouse gas concentrations in the atmosphere at levels that prevent dangerous, humaninduced warming of the climate. The Convention establishes a number of overarching principles for the international climate effort, including that the parties are to protect the climate system for present and future generations in accordance with their common but differentiated responsibilities and capabilities. Further, that industrialised countries have a special responsibility to take the lead in the work to prevent climate change.

The importance of forests in the context of climate change has attracted much political attention at a global level. The UNFCCC and the Kyoto Protocol require that the parties are to protect and strengthen "sinks" for greenhouse gases and carbon storage in biomass and soil, for example by reducing deforestation and encouraging sustainable forestry and reforestation. According to the Kyoto Protocol, the parties are to report greenhouse gas emissions and uptake within the Land-use, Land-use change and Forestry (LULUCF) sector.

CBD: The goal of the Convention on Biological Diversity is to promote the conservation and sustainable use of the world's biological diversity. The Convention has three overriding goals: 1) the conservation of biological diversity, 2) the sustainable use of the components of biological diversity and 3 ) the fair division of profit from the use of genetic resources. A central concept in CBD is the Ecosystem Approach. In general terms, this means that biological diversity should be seen in a landscape perspective that includes economic and social factors.
It is estimated that 70 per cent of the world's terrestrial plant and animal species are found in forest ecosystems. Forest issues are, therefore, an important aspect of CBD. More recently, the issue of illegal logging and the trade in illegally harvested wood has become a major topic for CBD. Also, as a result of the Cartagena Protocol, discussions on genetically modified trees (GMT) have intensified in recent years with several parties calling for a moratorium for the use of GMT.

UNCCD: The Convention's purpose is to prevent the degradation of lands, mitigate the effects of drought and contribute to sustainable development and better living condition for people living in dry areas. Arid areas account for one third of the earth's land surface and ultimately UNCCD is about the living conditions of close to 1 billion people who live in arid, semi-arid and dry sub-humid areas. UNCCD is implemented by means of national action Programs whose purpose is to address the underlying causes of deforestation and to find ways to prevent this.

Forests provide important ecological benefits which reduce the vulnerability of dry ecosystems. One of UNCCD's objectives, therefore, is to protect forests. Wood and forest products are also of great socio-economic importance to the people living in these areas.

ITTA: The International Tropical Timber Agreement is one of a number of commodity agreements that have been negotiated within the framework of the United Nations Conference on Trade. Unlike other commodity agreements, the ITTA does not contain any direct trade regulations. The overriding goal is to promote the expansion and diversification of international trade in tropical forestry. 
The International Tropical Timber Organization (ITTO) oversees the implementation of the agreement. Members of ITTO are countries that produce and consume tropical timber.

CITES: The purpose of the Convention is to ensure that no species of wild fauna or wild flora is subject to unsustainable exploitation because of international trade. This is done via regulation of trade through a system of import and export permits. Some 5,000 animal species and 28,000 plant species are protected to varying degrees by the Convention. They are listed on one of CITES' three lists (Appendix I, II and III), which group species on the basis of how threatened they are considered to be by international trade.

A large number of the species listed in CITES have forests as their habitat. In recent years a number of commercial tree species have been added to the lists.

ILO: The International Labour Organization is the UN's specialised body for employment and workrelated issues. Its overriding purpose is to alleviate poverty and promote social justice. More than 180 conventions on different aspects of social rights have been adopted over the years. For many years, the organization has been monitoring the working and living conditions of indigenous peoples. The purpose of ILO's Convention No. 169 is to strengthen indigenous peoples' socioeconomic and cultural rights. The main principle is that indigenous peoples shall be consulted and participate in decision-making in matters that affect their lives and communities.

Many indigenous and tribal peoples are dependent on forests and what the forests can provide for their livelihood. The Convention has established that the rights of indigenous peoples to natural resources pertaining to their land shall be safeguarded. This also includes their right to participate in the use, management and conservation of these resources.

Convention Concerning the Protection of the World Cultural and Natural Heritage: The purpose of the Convention is to establish an effective system for the protection of natural and cultural sites and other properties that are deemed to be part of a universal world heritage. The Convention maintains a list - the UNESCO World Heritage list of sites of universal value that are to be preserved. The World Heritage Committee makes decisions as to whether a property should be inscribed on the World Heritage list. Once a property has been inscribed on this list it is guaranteed care and protection for all time. The Convention requires affiliated states to have a suitable organization and legislation to ensure the protection and upkeep of world heritage sites on their territory.

Under the Convention, forests can be regarded as part of our natural heritage. In 2001, the World Heritage Committee agreed that forests eligible for conservation required special attention, and it therefore launched a Program for forests known as the World Heritage Forest Program (http:// whc. unesco.org/en/forests). In 2013 there were 97 forests having a total area of 76 million hectares on the World Heritage List.

Wetlands Convention: The purpose of the Convention, or Ramsar, as it is also known, is to preserve wetlands of international importance. There are 2,241 wetland areas, having a total area of more than 215 million hectares that are inscribed on the Ramsar list of Wetlands of International Importance.

Wetlands in the sense used in the Convention include marshy forests, mangroves and certain coastal forest areas.

Convention on Long-Range Transboundary Air Pollution (CLRTAP): The purpose of the Convention is to reduce damage to natural resources caused by acidification due to sulphur dioxide, nitrogen dioxide and other pollutants created by the combustion of fossil fuels. The Convention is a framework convention and, as such, it is formulated in general terms.

The Convention includes, as one among a number of other joint Programs, a Program for monitoring the effect of air pollution on forests; it is known as ICP Forests. 
UNFF: The United Nations Forum on Forests aims to promote the sustainable management of the world's forests and strengthen long-term political commitment amongst the member states to this end. A Collaborative Partnership on Forests is affiliated to the forum. The partnership consists of 14 international organizations that are involved in various ways with forest related policy, among them the FAO, the World Bank and ITTO as well as the secretariats for the conventions on climate, biological diversity, and desertification. The purpose of the partnership is to support the work of the UNFF and to foster closer cooperation and coordination on international forest-related issues.

The United Nations forest instrument adopted in 2007, formally known as Non-Legally Binding Instrument on All Types of Forests, or NLBI, provides countries with a framework for promoting sustainable forest management. The Instrument articulates a series of agreed policies and measures at the international and national levels to strengthen forest governance, technical and institutional capacity, policy and legal frameworks, forest sector investment and stakeholder participation. 


\section{APPENDIX 2: LEGISLATION}

FOREST AND RELATED LAWS

Forest Law Nr. 6831 (Official Gazette Date/Nr.: Mar 16th 2007 / 26464)

Forestry Law No 3116 and Laws No's 4785, 5653 and 5658 amending this law

Environmental Law Nr. 2872

National Parks law Nr. 2873

National Afforestation and Erosion Control Law Nr. 4122

Hunting Law Nr. 4915

Soil Protection and Land Use Law Nr. 5403

Protection of Cultural nad National Heritage Law Nr. 2863

Law Amending and Adopting Decree Law No 3234 on the Organization and Tasks of the Forestry General Directorate Cadastral Law Nr. 3402 Amended by Law Nr. 5304 (official gazette 17th June 1987 / 1952)

Law No 645 on the Organization and Tasks of the Ministry Of Forestry And Hydraulic Works

Village Law: Law Number: 442, accepted date: 18/3/1924, official gazette: 7/4/1924, volume:5, issue : 68

Mining Law: Law Number: 3213, published official gazette: date : 15/6/1985, issue : 18785,

Rangeland Law Nr. 4342

Law on Water Nr. 831

Law on Village Drinking Water Nr. 7478

Forest Engineering, Forest Industry Engineering and Woodworking Industry Engineering, Nr. 5531 (Official gazette: $8 / 07 / 2006$, issue 26222)

\section{REGULATIONS}

Regulations of Environmental Impact Assessment official gazette: 17/6/2008, issue : 26939

Regulations of afforestation official gazette : 09/10/2003, issue : 25254

Regulations of controlling earth masses, debris and ruined wastes official gazette: 18/3/2004, issue : 25406

Regulations of enhancement of degraded lands due to mining: official gazette :14/12/2007, issue : 26730

Regulations of transportation license of carrying wood products: official gazette : 04/06/2004, issue : 25482,

Regulations of enhancing forest road plans: official gazette: 01/07/2007, issue : 26569

Regulations of controlling waste oil: official gazette: 30/07/2008, issue : 26952

Regulations of Forest management:official gazette : 05/02/2008, issue : 26778

Regulation on transport certificates for forest products: official gazette: 04/04/2004, issue: 25482

Regulation on Working Conditions of employees in works in agriculture and forestry: official gazette: 04/042004, issue 25425

\section{INTERNATIONAL CONVENTIONS AND PROCESSES}

Intergovernmental Forestry Panel (IPF)

Intergovernmental Forestry Forum (IFF)

United Nations (UN) Forestry Forum (UNFF)

United Nations (UN) Convention on Control of Desertification

United Nations (UN) Framework Convention on Climate Change

United Nations (UN) Bio-Diversity Convention

Convention on the Preservation of Wetlands of International Significance Especially As the Habitat of Water Birds (RAMSAR Convention)

"Convention on the Protection of Wildlife and Habitats in Europe" (BERN CONVENTION)

Convention on the International Trade of Endangered Species of Wild Animals and Plants (CITES)

International Convention on the Protection of Birds

Convention on the Protection of World Cultural and Natural Heritage

Convention on the Protection of the Mediterranean Sea Against Pollution (BARCELONA)

European Landscaping Convention, EU Nature Protection Directives 


\section{APPENDIX 3: DETERMINANTS OF MIGRATION}

The econometric analysis is based on three different models that have alternative specifications of migration. The first is a probit model with the dependent variable defined as households with migrants within the past five years $(2011-2016=1)$ and no migrants $(=0)$. The second model is a probit model with the dependent variable defined as having migrants 5-10 years ago - between 2005$2010(=1)$ and no migrants ( $=0)$. The third model is an ordered logit model that defines the dependent variable as households with permanent migrants $(=1)$; with a member who intends to migrate (=2) and households with no migrants ( $=3$ ). Each model includes covariates at the household and village level. For the ordered logit, the impact of household and village covariates can be estimated using the following equation:

$\log \left(\frac{P i}{1-P i}\right)=\partial+\beta_{1} X_{h h}+\beta_{2} W_{\text {village }}+u$

where $\mathrm{Pi}$ is the probability of being in migration status I, $i=1$ (permanent migration), $=2$ (potential migration) and $=3$ (no migration). Xhh are household variables including age, education of household head, log household income, membership of forest cooperative, membership in other cooperatives, and household asset indices. Wvillage are village level characteristics such as living in a village with water network.

\begin{tabular}{|c|c|c|c|}
\hline & Within 5 years Col-1 & Between 5-10 years Col-2 & Ordered logit Col-3 \\
\hline \multicolumn{4}{|l|}{ Education of household head } \\
\hline Never in school & \multicolumn{2}{|l|}{0.012} & 0.065 \\
\hline Primary school & \multirow{2}{*}{$\begin{array}{r}0.0 / 3 \\
-0.254\end{array}$} & 0.301 & -0.058 \\
\hline Mid-high school & & -0.063 & 0.150 \\
\hline Age of household head & $0.156^{*}$ & -0.046 & 0.023 \\
\hline (Age of household head)^2 & $-0.001^{*}$ & 0.001 & -0.001 \\
\hline Male household head & -0.072 & -0.050 & 0.250 \\
\hline Household size & $-0.119^{* * *}$ & $-0.149 * * *$ & $0.125^{* * *}$ \\
\hline $\log$ (total income) & $0.086 *$ & $0.095^{*}$ & $-0.097^{*}$ \\
\hline Share of forest income & $0.491^{* *}$ & $0.393^{*}$ & $-0.526^{* *}$ \\
\hline Share of non-forest wage income & -0.078 & -0.225 & 0.325 \\
\hline $\mathrm{HH}$ is member of forest coop & $-0.498^{*}$ & -0.188 & 0.333 \\
\hline $\mathrm{HH}$ is member of other coops & 0.086 & 0.060 & -0.133 \\
\hline $\mathrm{HH}$ has internet access & -0.329 & 0.006 & $0.476^{*}$ \\
\hline $\mathrm{HH}$ is owner of livestock & $0.267^{*}$ & $0.285^{*}$ & -0.229 \\
\hline $\mathrm{HH}$ has tractor & 0.033 & -0.116 & 0.153 \\
\hline Living in village with water network & 0.010 & 0.026 & -0.003 \\
\hline Asset index principle component-1 & 0.044 & 0.005 & -0.050 \\
\hline Asset index principle component-2 & 0.003 & 0.083 & -0.042 \\
\hline Asset index principle component-3 & 0.002 & -0.012 & -0.004 \\
\hline Constant & $-5.595^{* * *}$ & -1.206 & \\
\hline
\end{tabular}




\section{APPENDIX 4: TURKEY'S INTENDED NATIONAL DETERMINED CONTRIBUTION (INDC)}

In accordance with decisions 1/CP.19 and 1/ CP.20, the Republic of Turkey hereby presents its Intended Nationally Determined Contribution (INDC) towards achieving the ultimate objective of the United Nations Framework Convention on Climate Change which is set out in its Article 2 and clarifying information.

\section{National Circumstances}

Turkey achieved 230 per cent increase in GDP between 1990 and 2012. Its population has increased more than 30 per cent since 1990. Turkey's energy demand increases by 6-7 percent every year.

Turkey is an upper-middle income developing country according to the World Bank classification. Turkey remains eligible to official development assistance (ODA).

Turkey is listed in Annex I to the UNFCCC. However, Decision 1/CP.16 recognized the special circumstances of Turkey and placed Turkey in a different situation than the other Parties included in Annex I.
Turkey aims to contribute to the collective efforts to combat climate change in line with its national circumstances and capabilities.

With this perspective, National Strategy on Climate Change and National Climate Change Action Plan were adopted in 2010 and 2011 respectively.

National Climate Change Action Plan consists of emission control and adaptation policies and measures which are being implemented in all relevant sectors.

The greenhouse gas inventory of the year 2012 revealed that the total emissions in 2012 expressed in $\mathrm{CO}_{2}$ equivalent were 440 million tons in Turkey. The energy sector had the largest share with 70.2 percent. Industrial processes with 14.3 percent, waste sector with 8.2 percent and agriculture with 7.3 percent followed the energy sector. Turkey's per capita greenhouse gas ( $\mathrm{GHG}$ ) emission for the same year was 5.9 ton $\mathrm{CO}_{2}$ equivalent, which is much lower than the EU and OECD average.

\section{INFORMATION ON INDC}

\begin{tabular}{|c|c|}
\hline INDC & $\begin{array}{l}\text { Up to } 21 \text { percent reduction in GHG emissions from the Business as Usual (BAU) level } \\
\text { by } 2030 \text {. }\end{array}$ \\
\hline $\begin{array}{l}\text { Period for Implementation } \\
\text { or Contribution }\end{array}$ & $2021-2030$ \\
\hline Scope and Coverage & $\begin{array}{l}\text { Economy-wide. } \\
\text { Energy, industrial processes and products use, agriculture, land use land-use change } \\
\text { and forestry, and waste sectors. }\end{array}$ \\
\hline GHGs & $\begin{array}{l}\text { All greenhouse gases included in the national inventory: } \\
\text { - Carbon dioxide }\left(\mathrm{CO}_{2}\right) \text {; } \\
\text { - Methane ( } \mathrm{CH} 4) \text {; } \\
\text { - Nitrous oxide (N2O); } \\
\text { - Hydrofluorocarbons (HFCs); } \\
\text { - Perfluorocarbons (PFCs); } \\
\text { - Sulfur hexafluoride (SF6); } \\
\text { - Nitrous trifluoride (NF3). }\end{array}$ \\
\hline
\end{tabular}




Methodological
approaches
Use of International
Market Mechanisms
Consideration of fairness
and ambition based on
national conditions

How the INDC contributes
to achieving the
ultimate objective of the
Convention (Article 2)
Planning Process

Planning Process

Financial Needs
Methodological approaches are based on using the IPCC 2006 Guidelines and IPCC 2013 KP Supplement.

Global warming potential on a 100 year timescale in accordance with the IPCC's 4th Assessment Report.

Turkey aims to use carbon credits from international market mechanisms to achieve its 2030 mitigation target in a cost effective manner and in accordance with the relevant rules and standards.

Turkey has to continue its sustainable development process.

Rapid industrialization and urbanization have been taking place in Turkey over the last 30 years.

Turkey is responsible for only 0.7 percent of the global emissions since the industrial revolution.

Energy imports have a significant share in Turkey's account deficit. Turkey has to use its limited energy resources.

Turkey experiences financial and technological constraints in combating climate change.

This INDC provides additional policies, plans and measures in many sectors.

Up to 21 percent reduction in GHG emissions from the BAU level by 2030 will enable Turkey to step on low-carbon development pathways compatible with the long-term objective of limiting the increase in global temperature below $2^{\circ} \mathrm{C}$.

\section{Turkey may revise this INDC in accordance with changing circumstances.}

Turkey supports its INDC through a national climate change policy which includes;

- 10th National Development Plan

- National Strategy on Climate Change

- National Climate Change Action Plan

- National Strategy on Industry

- Strategy on Energy Efficiency

- National Strategy and Action Plan on Recycling

- National Legislation on Monitoring, Reporting and Verification of GHG emissions

- National Smart Transportation Systems Strategy Document (2014-2023) and its Action Plan (2014-2016)

Turkey's INDC was prepared in a participatory approach through multiple stakeholder meetings and by analytical studies conducted for 1 year.

Times-MACRO model is used for energy related modelling and other national models and studies are used for non-energy sectors.

Recalling the decisions 26/CP.7, 1/CP.16, 2/CP.17, 1/CP.18 and 21/CP.20, in view of successfully implementing this INDC, Turkey will use domestic sources and receive international financial, technological, technical and capacity building support, including finance from the Green Climate Fund.

\section{Plans and policies to be implemented for the INDC, by sector:}

\section{Energy}

- Increasing capacity of production of electricity from solar power to $10 \mathrm{GW}$ until 2030

- Increasing capacity of production of electricity from wind power to 16 GW until 2030

- Tapping the full hydroelectric potential

- Commissioning of a nuclear power plant until 2030
- Reducing electricity transmission and distribution losses to 15 percent at 2030

- Rehabilitation of public electricity generation power plants

- Establishment of micro-generation, co-generation systems and production on site at electricity production 


\section{Industry}

- Reducing emission intensity with the implementation of National Strategy and Action Plan on Energy Efficiency

- Increasing energy efficiency in industrial installations and providing financial support to energy efficiency projects

- Making studies to increase use of waste as an alternative fuel at the appropriate sectors

\section{Transport}

- Ensuring balanced utilization of transport modes in freight and passenger transport by reducing the share of road transport and increasing the share of maritime and rail transport

- Enhancing combined transport

- Implementing sustainable transport approaches in urban areas

- Promoting alternative fuels and clean vehicles

- Reducing fuel consumption and emissions of road transport with National Intelligent Transport Systems Strategy Document (20142023) and its Action Plan (2014-2016)

- Realizing high speed railway projects

- Increasing urban railway systems

- Achieving fuel savings by tunnel projects

- Scrapping of old vehicles from traffic

- Implementing green port and green airport projects to ensure energy efficiency

- Implementing special consumption tax exemptions for maritime transport

\section{Buildings and Urban Transformation}

- Constructing new residential buildings and service buildings as energy efficient in accordance with the Energy Performance of Buildings Regulations

- Creating Energy Performance Certificates for new and existing buildings so as to control energy consumption and greenhouse gas emissions and to reduce energy consumption per square meter

- Reducing the consumption of primary energy sources of new and existing buildings by means of design, technological equipment, building materials, development of channels that promote the use of renewable energy sources (loans, tax reduction, etc.)
- Dissemination of Green Building, passive energy, zero-energy house design in order to minimize the energy demand and to ensure local production of energy

\section{Agriculture}

- Fuel savings by land consolidation in agricultural areas

- Rehabilitation of grazing lands

- Controlling the use of fertilizers and implementing modern agricultural practices

- Supporting the minimum tillage methods

\section{Waste}

- Sending solid wastes to managed landfill sites

- Reuse, recycle and use of other processes to recover secondary raw materials, to utilize as energy source or to remove wastes

- Recovering energy from waste by using processes such as material recycling of wastes, bio-drying, bio-methanization, composting, advanced thermal processes or incineration

- Recovery of methane gas from landfill gas from managed and unmanaged landfill sites

- Utilization of industrial wastes as an alternative raw material or alternative fuel in other industrial sectors, through industrial symbiosis approach

- Conducting relevant studies to utilize wastes generated from breeding farms and poultry farms

- Rehabilitation of unmanaged waste sites and ensuring wastes to be deposited at managed landfill sites

\section{Forestry}

- Increasing sink areas and preventing land degradation

- Implementing Action Plan on Forestry Rehabilitation and National Afforestation Campaign

The emission reductions to be achieved by these policies and plans compared to the business-asusual scenario are presented in the figure below. 


\section{INDC Forestry Scenarios:}

\section{Reduction Scenario}

- GDF 2013-2017 Strategic Plan, National Forestry Program (2004-2023) taken into consideration,

- GDF achieved the 2023 target (forest area 30 percent=23.4 million ha of national territories)

- Productive forest area assumed to reach $12,000,000$ ha by 2030

\section{Reference Scenario}

- Afforestation figures before 1996 (20,000 ha/ year) remained constant,

- Insufficient rehabilitation,

- Increased population and settlement pressure,

- Afforestation potential assumed to decline.

\section{TURKEY'S INDC}

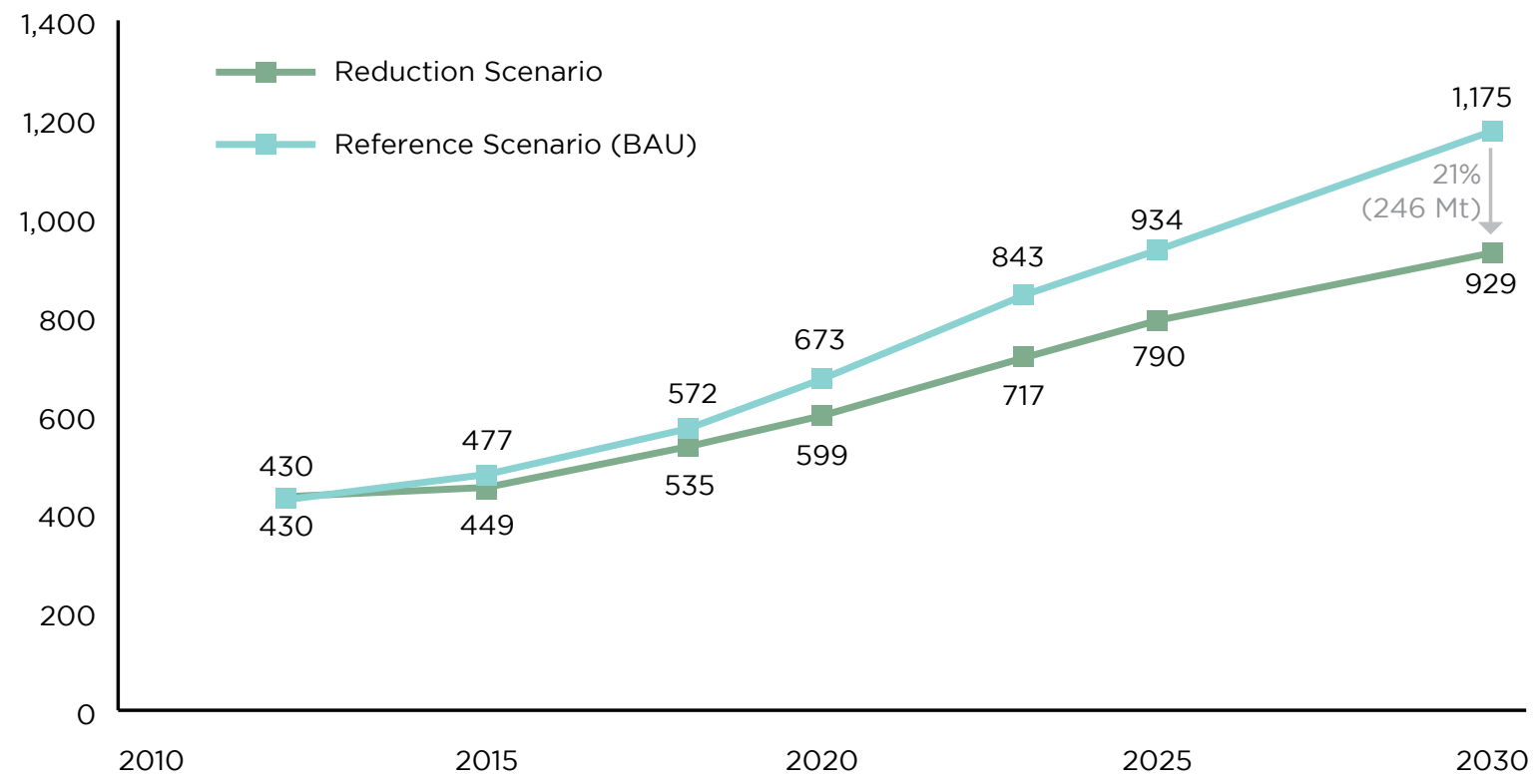

\section{TURKEY'S FORESTRY INDC COMMITMENT}

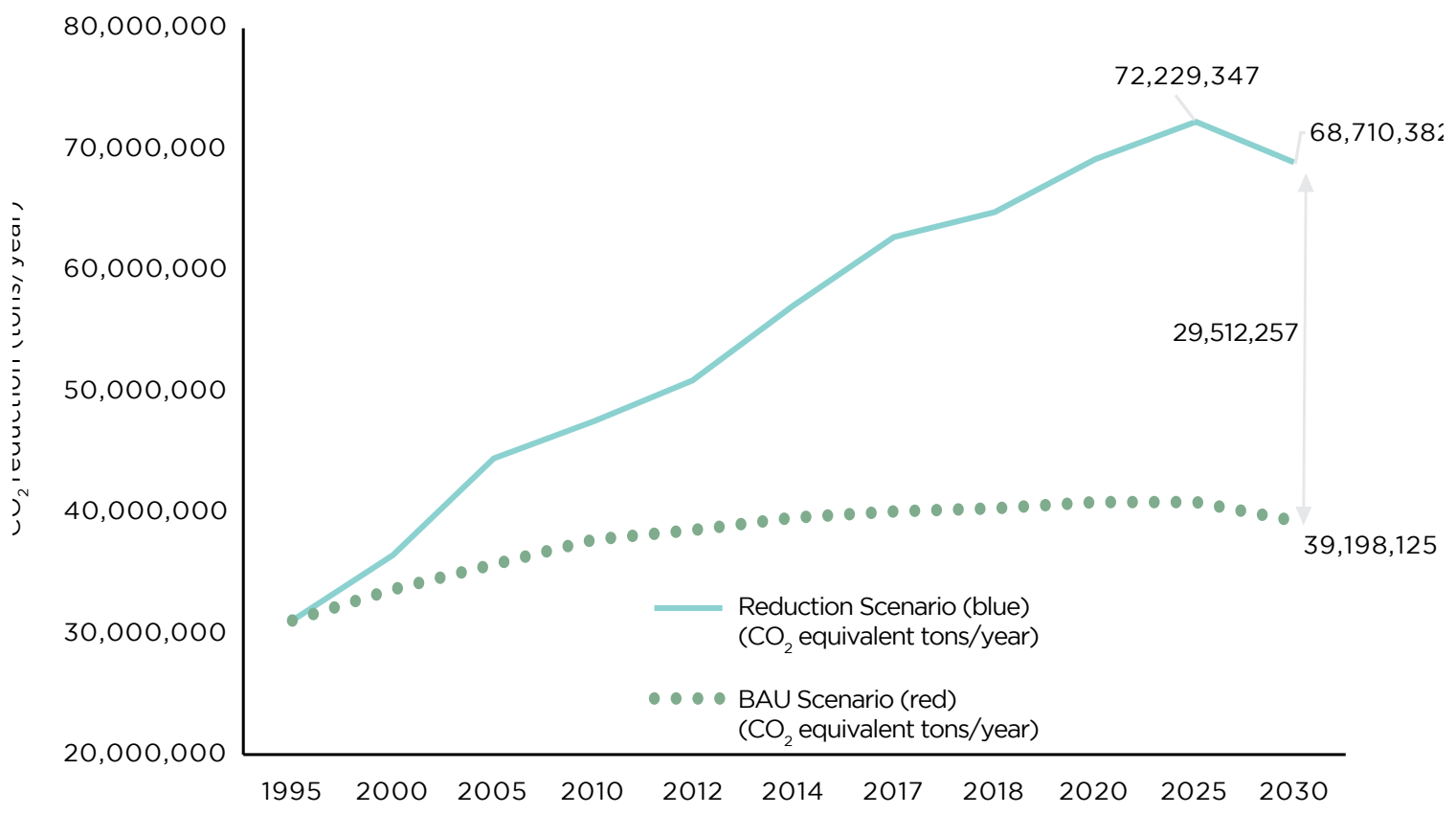




\section{APPENDIX 5: SFM CRITERIA AND INDICATORS}

\section{Criterion 1. Forest resources}

1.1. Forests and other wooded areas

1.2. Growing stock, biomass and carbon stock

1.3. Increment

1.4. Forested area which under management plan

1.5. Forested land of which cadastre is finalized

(legally registered)

\section{Criterion 2. Biologic Diversity}

2.1. Fragmentation of forests

2.2. Silvicultural treatments (maintenance)

2.3. Regeneration reliability

2.4. Seed resources

\section{Criterion 3. Health \& Vitality of forests}

3.1. Forests affected by natural factors

3.2. Successfully regenerated forest area

3.3. Forest area cleared (forest cover is disappeared/ shifted) and settlement set

3.4. Consumption of fuel wood

3.5. Forest fires

3.6. Damages made by grazing

3.7. Using permission and easement
Criterion 4. Production capacity and functions of forests

4.1. Forest area which is being managed by integrated management plans

4.2. Wood production

4.3. Balance between production and increment

4.4. Production of NWFPs

Criterion 5. Protective and Environmental functions of forests

5.1. Conservation forests

5.2. Forests for protection of water reservoirs

5.3. Soil protection forests

Criterion 6. Socio-economic functions

6.1. Value of wood produced

6.2. Value of NWFPs

6.3. Employment created by forestry implementation

6.4. Forest communities and NGOs

6.5. Forestry related offences 


\section{APPENDIX 6: SHARE OF DIRECT AND INDIRECT IMPACTS OF GROWTH IN THE FORESTRY SECTOR, 2002}

Product sector

O2 Products of forestry, logging and related services

20 Wood and products of wood and cork (except furniture); articles of straw and plaiting materials

21 Pulp, paper and paper products

37 Secondary raw materials

36 Furniture; other manufactured goods n.e.c.

2 Printed matter and recorded media

10 Coal and lignite; peat

73 Research and development services

Tobacco products

Metal ores

5 Hotel and restaurant services

Construction work

4 Other business services

Basic metals

Other non-metallic mineral products

8 Fabricated metal products, except machinery and equipment

Radio, television and communication equipment and apparatus

Direct Indirect

$65,276 \quad 64,605$

$9,432 \quad 1,680$

3,058 $\quad 974$

$1,023 \quad 1,023$

$862 \quad 726$

$846 \quad 794$

$746 \quad 63$

$403 \quad 191$

$367 \quad 367$

$333 \quad 79$

$287 \quad 90$

$275 \quad 272$

$231 \quad 222$

$210 \quad 201$

$203 \quad 182$

$196 \quad 178$

$196 \quad 194$

Rubber and plastic products

$189 \quad 164$

$179 \quad 158$

$171 \quad 171$

$170 \quad 154$

$163 \quad 116$

$156 \quad 153$

$155 \quad 75$

$154 \quad 107$

$154 \quad 152$

$152 \quad 147$

$152 \quad 150$

$149 \quad 143$

$139 \quad 131$

$135 \quad 133$

$130 \quad 60$
and household goods

Recreational, cultural and sporting services

$124 \quad 108$

$119 \quad 102$

\begin{tabular}{|r|r|r|}
\hline Other services & 114 & 83 \\
\hline
\end{tabular}

Trade, maintenance and repair services of motor vehicles and motorcycles; retail sale of automotive fuel

$111 \quad 73$


Product sector

18 Wearing apparel; furs

51 Wholesale trade and commission trade services, except of motor vehicles and motorcycles

66 Insurance and pension funding services, except compulsory social security services

80 Education services

40 Electrical energy, gas, steam and hot water

71 Renting services of machinery and equipment without operator and of personal and household goods

75 Public administration and defence services; compulsory social security services

65 Financial intermediation services, except insurance and pension funding services

64 Post and telecommunication services

63 Supporting and auxiliary transport services; travel agency services

60 Land transport; transport via pipeline services

90 Sewage and refuse disposal services, sanitation and similar services

11 Crude petroleum and natural gas; services incidental to oil and gas extraction excluding surveying

62 Air transport services

23 Coke, refined petroleum products and nuclear fuels

05 Fish and other fishing products; services incidental of fishing

70 Real estate services

01 Products of agriculture, hunting and related services

61 Water transport services

41 Collected and purified water, distribution services of water

95 Private households with employed persons
Direct Indirect

$109 \quad 108$

$108 \quad 88$

$108 \quad 108$

\begin{tabular}{l}
$97 \quad 73$ \\
\hline
\end{tabular}

$87 \quad 82$

$87 \quad 79$

$86 \quad 86$

\begin{tabular}{l|l}
82 & 82
\end{tabular}

$81 \quad 80$

$77 \quad 72$

6969

$69 \quad 67$

$68 \quad 68$

$68 \quad 67$

$67 \quad 67$

$65 \quad 40$

$65 \quad 45$

$41 \quad 38$

$37 \quad 36$

$35 \quad 35$

$0 \quad 0$



